\title{
The IPAC-NC field campaign: a pollution and oxidization pool in the lower atmosphere over Huabei, China
}

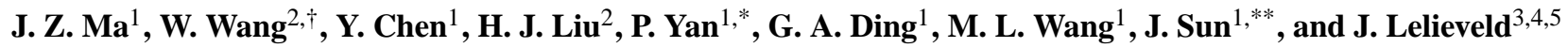 \\ ${ }^{1}$ Chinese Academy of Meteorological Sciences, Beijing, China \\ ${ }^{2}$ Chinese Research Academy of Environmental Sciences, Beijing, China \\ ${ }^{3}$ Max Planck Institute for Chemistry, Mainz, Germany \\ ${ }^{4}$ Cyprus Institute, Nicosia, Cyprus \\ ${ }^{5}$ King Saud University, Riyadh, Saudi Arabia \\ *now at: CMA Meteorological Observation Centre, Beijing, China \\ ** now at: CMA Numerical Prediction Centre, Beijing, China \\ $\dagger$ deceased, March 2010
}

Correspondence to: J. Z. Ma (mjz@cams.cma.gov.cn)

Received: 5 September 2011 - Published in Atmos. Chem. Phys. Discuss.: 12 October 2011

Revised: 29 March 2012 - Accepted: 8 April 2012 - Published: 3 May 2012

\begin{abstract}
In the past decades, regional air pollution characterized by photochemical smog and grey haze-fog has become a severe environmental problem in China. To investigate this, a field measurement campaign was performed in the Huabei region, located between $32-42^{\circ} \mathrm{N}$ latitude in eastern China, during the period 2 April-16 May 2006 as part of the project "Influence of Pollution on Aerosols and Cloud Microphysics in North China" (IPAC-NC). It appeared that strong pollution emissions from urban and industrial centers tend to accumulate in the lower atmosphere over the central area of Huabei. We observed widespread, very high $\mathrm{SO}_{2}$ mixing ratios, about $20-40 \mathrm{ppbv}$ at $0.5-1.5 \mathrm{~km}$ altitude and $10-30 \mathrm{ppbv}$ at $1.5-3.0 \mathrm{~km}$ altitude. Average $\mathrm{CO}$ mixing ratios were $0.65-0.7 \mathrm{ppmv}$ at $0.5-1.5 \mathrm{~km}$ altitude, and very high $\mathrm{CO}$ around $1 \mathrm{ppmv}$ was observed during some flights, and even higher levels at the surface. We find the high pollution concentrations to be associated with enhanced levels of $\mathrm{OH}$ and $\mathrm{HO}_{2}$ radicals, calculated with a chemical box model constrained by the measurements. In the upper part of the boundary layer and in the lower free troposphere, high $\mathrm{CO}$ and $\mathrm{SO}_{2}$ compete with relatively less $\mathrm{NO}_{2}$ in reacting with $\mathrm{OH}$, being efficiently recycled through $\mathrm{HO}_{2}$, preventing a net loss of $\mathrm{HO}_{\mathrm{x}}$ radicals. In addition to reactive hydrocarbons and $\mathrm{CO}$, the oxidation of $\mathrm{SO}_{2}$ causes significant ozone production over Huabei (up to $\sim 13 \%$ or $2.0 \mathrm{ppbv} \mathrm{h}^{-1}$ at $0.8 \mathrm{~km}$ altitude). Our results indicate that the lower atmosphere over
\end{abstract}

Huabei is not only strongly polluted but also acts as an oxidation pool, with pollutants undergoing very active photochemistry over this part of China.

\section{Introduction}

The growing influence of gas and aerosol emissions from major urban and industrial centers on air quality and climate on regional to global scales is of great concern. In recent decades, intensive field campaigns and model studies have demonstrated that global air pollution is strongly affected by regional hot spots of air pollution (Lelieveld et al., 2002a; Akimoto, 2003; Lawrence et al., 2007). These hot spot regions of severe air pollution often include megacities $(>10$ million population) with strongly enhanced emissions from traffic, power generation and industrial activities (Molina and Molina, 2004; Gurjar et al., 2008). While urban and regional pollution in the traditional industrialized countries continues to provide environmental challenges, the attention for developing and newly industrialized regions, e.g. in Central America (Molina et al., 2007, 2010), the Mediterranean (Kanakidou et al., 2011), Middle East (Lelieveld et al., 2009) and South and East Asia (Chan and Yao, 2008; Zhang et al., 2008b; Lawrence and Lelieveld, 2010; Ma et al., 2010), is intensifying. 
Photochemical smog has become a major concern in the urban environment (Molina and Molina, 2004). Emissions of nitrogen oxides $\left(\mathrm{NO}_{\mathrm{x}} \equiv \mathrm{NO}+\mathrm{NO}_{2}\right)$, carbon monoxide $(\mathrm{CO})$ and volatile organic compounds (VOCs) drive the photochemical formation of ozone $\left(\mathrm{O}_{3}\right)$ and other oxidants, degrading air quality and adversely affecting human health, ecosystems and agricultural productivity (Molina et al., 2010). Atmospheric ozone production, $P\left(\mathrm{O}_{3}\right)$, over urban centers generally involves different stages, from being VOC-sensitive near the source(s) to being rather more $\mathrm{NO}_{\mathrm{x}}-$ sensitive further downwind (Sillman, 1999; Solomon et al., 2000; Kleinman et al., 2005; Kuhn et al., 2010). Photochemical smog episodes are accompanied by high aerosol loads, causing haze pollution with potential impacts on human health, climate and the hydrological cycle (Ramanathan et al., 2005; Pope and Dockery, 2006; Ma et al., 2010). These aerosols, mainly consisting of fine particles, originate either directly from traffic, industrial activity and biomass burning (primary particles), or indirectly from the gas-to-particle conversion of low-volatile condensable inorganic and organic gases (secondary particles), formed via a complex sequence of oxidation reactions of gaseous precursors from the same sources (Seinfeld and Pandis, 1998; Kulmala, 2003; Jimenez et al., 2009; Apel et al., 2010).

The oxidation of the gaseous precursors of ozone and secondary aerosols is mainly initiated by hydroxyl radicals $(\mathrm{OH})$, formed primarily through the photolysis of $\mathrm{O}_{3}$, nitrous acid $\left(\mathrm{HNO}_{2}\right)$ and hydrogen peroxide $\left(\mathrm{H}_{2} \mathrm{O}_{2}\right)$ (Levy, 1971; Ehhalt, 1999).

$$
\begin{aligned}
& \mathrm{O}_{3}+h v(\lambda<320 \mathrm{~nm}) \longrightarrow \mathrm{O}\left({ }^{1} \mathrm{D}\right)+\mathrm{O}_{2}, \\
& \mathrm{O}\left({ }^{1} \mathrm{D}\right)+\mathrm{H}_{2} \mathrm{O} \longrightarrow 2 \mathrm{OH} . \\
& \mathrm{HNO}_{2}+h v \longrightarrow \mathrm{OH}+\mathrm{NO} . \\
& \mathrm{H}_{2} \mathrm{O}_{2}+h v \longrightarrow 2 \mathrm{OH} .
\end{aligned}
$$

The reactions of $\mathrm{OH}$ with $\mathrm{CO}$ and VOCs (expressed as $\mathrm{RH}$ in Reaction R5) produce hydroperoxy $\left(\mathrm{HO}_{2}\right)$ and organic peroxy $\left(\mathrm{RO}_{2}\right)$ radicals, respectively.

$$
\mathrm{CO}+\mathrm{OH} \stackrel{\mathrm{O}_{2}}{\longrightarrow} \mathrm{HO}_{2}+\mathrm{CO}_{2} \text {. }
$$

$\mathrm{RH}+\mathrm{OH} \stackrel{\mathrm{O}_{2}}{\longrightarrow} \mathrm{RO}_{2}+\mathrm{H}_{2} \mathrm{O}$.

$\mathrm{RO}_{2}$ (expressed as $\mathrm{R}^{\prime} \mathrm{CH}_{2} \mathrm{O}_{2}$ in Reaction R6) is converted to $\mathrm{HO}_{2}$ through reaction with $\mathrm{NO} . \mathrm{HO}_{2}$ further reacts with $\mathrm{NO}$ to recycle $\mathrm{OH}$.

$\mathrm{R}^{\prime} \mathrm{CH}_{2} \mathrm{O}_{2}+\mathrm{NO} \stackrel{\mathrm{O}_{2}}{\longrightarrow} \mathrm{R}^{\prime} \mathrm{CHO}+\mathrm{NO}_{2}+\mathrm{HO}_{2}$.

$\mathrm{HO}_{2}+\mathrm{NO} \longrightarrow \mathrm{OH}+\mathrm{NO}_{2}$.

$\mathrm{NO}_{2}$ produces $\mathrm{O}_{3}$ and reforms $\mathrm{NO}$ upon photolysis by sunlight.

$\mathrm{NO}_{2}+h v(\lambda<420 \mathrm{~nm}) \stackrel{\mathrm{O}_{2}}{\longrightarrow} \mathrm{NO}+\mathrm{O}_{3}$.
$\mathrm{NO}$ is also rapidly oxidized by $\mathrm{O}_{3}$ to $\mathrm{NO}_{2}$.

$\mathrm{NO}+\mathrm{O}_{3} \longrightarrow \mathrm{NO}_{2}+\mathrm{O}_{2}$.

Note that Reactions (R8)-(R9) represent a null cycle for ozone production in sunlight since there is no change in the $\mathrm{O}_{3}$ abundance at steady state. $\mathrm{Net}_{3}$ production takes place through Reactions (R6)-(R8).

In addition to the effective photodissociation of ozone (Reaction R1), ozone loss occurs through the $\mathrm{HO}_{\mathrm{x}}$ $\left(\equiv \mathrm{OH}+\mathrm{HO}_{2}\right)$ catalytic cycle and reactions with alkenes.

$\mathrm{HO}_{2}+\mathrm{O}_{3} \longrightarrow \mathrm{OH}+2 \mathrm{O}_{2}$.

$\mathrm{OH}+\mathrm{O}_{3} \longrightarrow \mathrm{HO}_{2}+\mathrm{O}_{2}$

Alkene $+\mathrm{O}_{3} \longrightarrow$ aldehyde + radicals.

Loss of $\mathrm{OH}$ occurs through the reaction with $\mathrm{NO}_{2}$, forming nitric acid $\left(\mathrm{HNO}_{3}\right)$.

$\mathrm{NO}_{2}+\mathrm{OH}+\mathrm{M} \longrightarrow \mathrm{HNO}_{3}+\mathrm{M}$.

$\mathrm{O}_{3}$ production through the catalytic cycle between $\mathrm{NO}$ and $\mathrm{NO}_{2}$ is thus associated with the competition for $\mathrm{OH}$ radicals by $\mathrm{CO}$, VOCs and $\mathrm{NO}_{\mathrm{x}}$, and a potential recycling between $\mathrm{OH}$ and $\mathrm{HO}_{2}$ (Kuhn et al., 2010). Additional $\mathrm{OH}$ results from the photolysis of $\mathrm{O}_{3}$ and can be amplified in the oxidation of VOCs, though the chemical mechanisms are not yet fully understood (Lelieveld et al., 2008; Hofzumahaus et al., 2009). How $\mathrm{OH}$ recycling may enhance the efficiency of atmospheric oxidation processes on urban to global scales needs further investigation of the organic radical chemistry, while empirical $\mathrm{HO}_{\mathrm{x}}$ budget studies have recently been reported, e.g. for Mexico City (Volkamer et al., 2010; Sheehy et al., 2010), for the rural area in the Pear River Delta, China (Lou et al., 2010), for the boundary layer and free troposphere (FT) over West Africa (Commane et al., 2010), for the tropical troposphere over the Amazon rainforest (Martinez et al., 2010; Kubistin et al., 2010), and for the Artic troposphere (Mao et al., 2010; Lelieveld, 2010).

Regional air pollution characterized by photochemical smog and haze-clouds (or haze-fog) has been recognized as one of the severe environmental problems in China (Zhang et al., 2008b; Ma et al., 2010). North China, or Huabei in Chinese (hereafter we use the latter), is a geographical region located between $32-42^{\circ} \mathrm{N}$ latitude in the northern part of eastern China, including several provinces and large municipalities, e.g. Beijing and Tianjin. Over the past decades, the region has actually become one of the most severely polluted regions worldwide. Air quality in Beijing, especially in relation to the 2008 Beijing Olympics, has been addressed by numerous studies, including special sections in the "Journal of Geophysical Research-Atmospheres" and "Atmospheric Chemistry and Physics". Air pollution in Beijing and the surrounding area impacts the air quality in Huabei, indicated 
by ground-based measurements in urban and suburban sites (Shao et al., 2009; Lu et al., 2010; Wang et al., 2010), rural sites (Li et al., 2007; Lin et al., 2009; Pan et al., 2009; Wang et al., 2009, 2010), regional background stations (Yan et al., 2008; Lin et al., 2008; Meng et al., 2009; Xu et al., 2011) and by aircraft measurements (Ding et al., 2008; Zhang et al., 2009a; Chen et al., 2009; Ma et al., 2010).

The air pollution outflow from Huabei may even impact tropospheric chemistry on continental and global scales. Several international field campaigns have investigated the outflow of emissions from East Asia, primarily China, e.g. TRACE-P (Transport and Chemical Evolution over the Pacific) (Jacob et al., 2003) and INTEX-B (Intercontinental Chemical Transport Experiment-B) (Singh et al., 2009). The results have shown that air pollutants from China can be detected over North America and even Europe through longdistance transport and associated chemical transformation processes (Zhang et al., 2008a; Barletta et al., 2009; Fiedler et al., 2009; Cooper et al., 2010). Research on photochemical and transport characteristics of regional pollution based on aircraft measurements within the source regions of China such as Huabei has yet been rarely reported. Apart from emissions in urban and industrial centers, Huabei is also affected by airborne mineral dust, especially during springtime. The combination of dust with ozone and aerosol precursors, e.g. $\mathrm{NO}_{\mathrm{x}}, \mathrm{VOCs}$ and $\mathrm{SO}_{2}$, give rise to a rather unique atmospheric composition over Huabei (Li et al., 2007; Lin et al., 2009; Ma et al., 2010).

The IPAC-NC (Influence of Pollution on Aerosols and Cloud Microphysics in North China) field measurement campaign was performed over Huabei during 2 April-16 May 2006 with the goal to understand the chemical pollution characteristics and the potential impact on climate. IPAC-NC was the first intensive field campaign to simultaneously address trace gases, aerosols and clouds by aircraft measurements over China. One important finding was the widespread occurrence of haze-clouds, characterized by very high concentrations of gaseous pollutants and aerosol particles mixed within low-level stratiform clouds (Ma et al., 2010). IPAC$\mathrm{NC}$ also revealed that oxidation reactions associated with $\mathrm{OH}$ play a central role in the formation and persistence of the haze-clouds (Ma et al., 2010). Here we analyze the data with a focus on trace gases, ozone photochemistry and the atmospheric oxidation capacity. In Sect. 2, we present an overview of the IPAC-NC campaign, including the emission sources and their geographical distributions, chemical weather conditions, the models used, measurement platforms and instruments, and aircraft flight information. In Sect. 3, we analyze the spatial pollution distribution characteristics during the campaign, investigate the regional oxidation capacity using a chemical box model constrained by measurements, and discuss the implications for ozone formation. The summary and conclusions are given in Sect. 4.

\section{Field experiment and models}

\subsection{Emissions and meteorology}

The IPAC-NC campaign was performed in the larger Beijing, Tianjin and Tangshan area (Jing-Jin-Tang in Chinese), with some flight tracks extending towards the Bohai Gulf. The research area was strongly influenced by air pollution emissions and transport from major urban and industrial centers in the Huabei region. According to an emission inventory for Huabei developed by our group (Zhao et al., 2012), anthropogenic emissions in the central area, i.e. the Beijing Municipality, Tianjin Municipality and Hebei Province (together forming Jing-Jin-Ji), in the year 2003 were: $2.06 \mathrm{Tg} \mathrm{SO}_{2}$, $1.58 \mathrm{Tg} \mathrm{NO}_{\mathrm{x}}$ (in equivalent $\mathrm{NO}_{2}$ ), $1.32 \mathrm{Tg} \mathrm{VOC}, 16.11 \mathrm{Tg}$ $\mathrm{CO}, 1.19 \mathrm{Tg} \mathrm{NH} \mathrm{N}_{3}, 2.65 \mathrm{Tg} \mathrm{PM}_{10}, 1.40 \mathrm{Tg} \mathrm{PM}_{2.5}, 0.11 \mathrm{Tg}$ elemental carbon (EC) and $0.25 \mathrm{Tg}$ organic carbon (OC). Figure 1 presents the spatial distributions of emission sources of primary air pollutants in Jing-Jin-Ji. The large emission centers coincide with megacities (Beijing $39.92^{\circ} \mathrm{N}, 116.46^{\circ} \mathrm{E}$ and Tianjin $39.02^{\circ} \mathrm{N}, 117.02^{\circ} \mathrm{E}$ ) and other large industrial centers (Tangshan $39.36^{\circ} \mathrm{N}, 118.11^{\circ} \mathrm{E}$, Shijiazhuang $38.02^{\circ} \mathrm{N}, 114.30^{\circ} \mathrm{E}$ ). While Jing-Jin-Ji is one of the major industrial areas in China, Shanxi Province in west Huabei (not shown) is important for its energy production, with large pollution sources (e.g. Taiyuan City $37.54^{\circ} \mathrm{N}, 112.33^{\circ} \mathrm{E}$ ), included in our database.

The IPAC-NC campaign was carried out in spring 2006. During this season warm and humid southerly and southwesterly winds prevail in the planetary boundary layer (PBL), often invaded by northwesterly cold, dry air masses. Above the PBL, westerly and northwesterly winds predominate. In addition to synoptic weather systems, the circulation pattern is influenced by the pronounced topography in the north and west of the Jing-Jin-Tang area (Xu et al., 2005; Chen et al., 2009). We added passive pollution tracers into the regional meteorological forecast model GRAPES (Global/Regional Assimilation and Prediction Enhanced System; Wu et al., 2005; Chen and Shen, 2006; Xue et al., 2008) to simulate the transport of pollutants from the large cities Beijing, Tianjin, Tangshan, Shijiazhuang and Taiyuan. The tracers were released from the five $0.3 \times 0.3^{\circ}$ model grids for each city in the lowest model layer. A constant tracer emission rate of $300 \mathrm{Mg} \mathrm{km}^{-2}$ was used for all selected grid cells, comparable to the $\mathrm{SO}_{2}$ and $\mathrm{NO}_{\mathrm{x}}$ emissions in these cities. Figure 2 shows the wind fields and spatial tracer distributions over Jing-Jin-Tang and the surrounding areas during the campaign period. In addition to the concentrated pollution hot spots near the ground, strongly enhanced tracer concentrations were predicted at higher altitudes up to $\sim 3 \mathrm{~km}$. The weak vertical winds and horizontal convergence lead to the accumulation of pollutants, thus resulting in an "air pollution pool" over the area. 

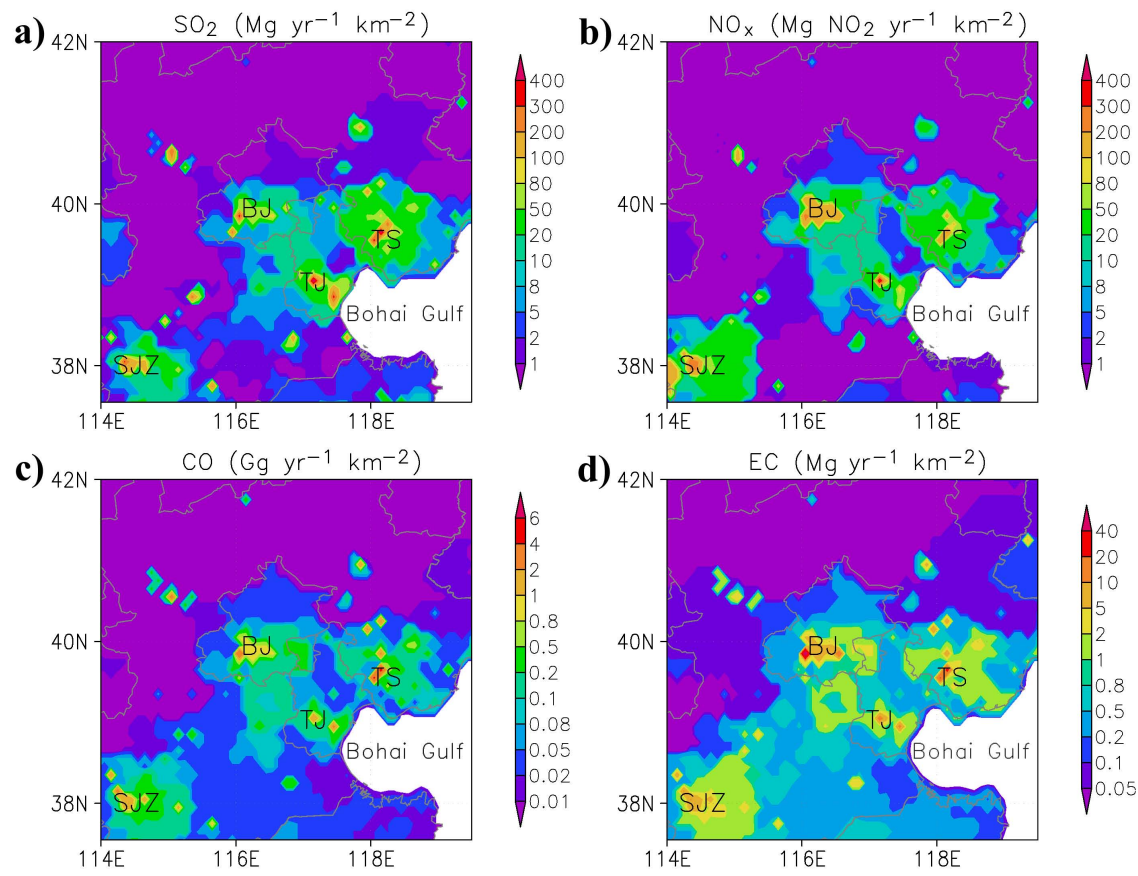

Fig. 1. Primary pollutant emissions in the central area of Huabei. Strong emissions from the Beijing (BJ), Tianjin (TJ), Tangshan (TS) and Shijiazhuang (SJZ) cities are clearly visible.
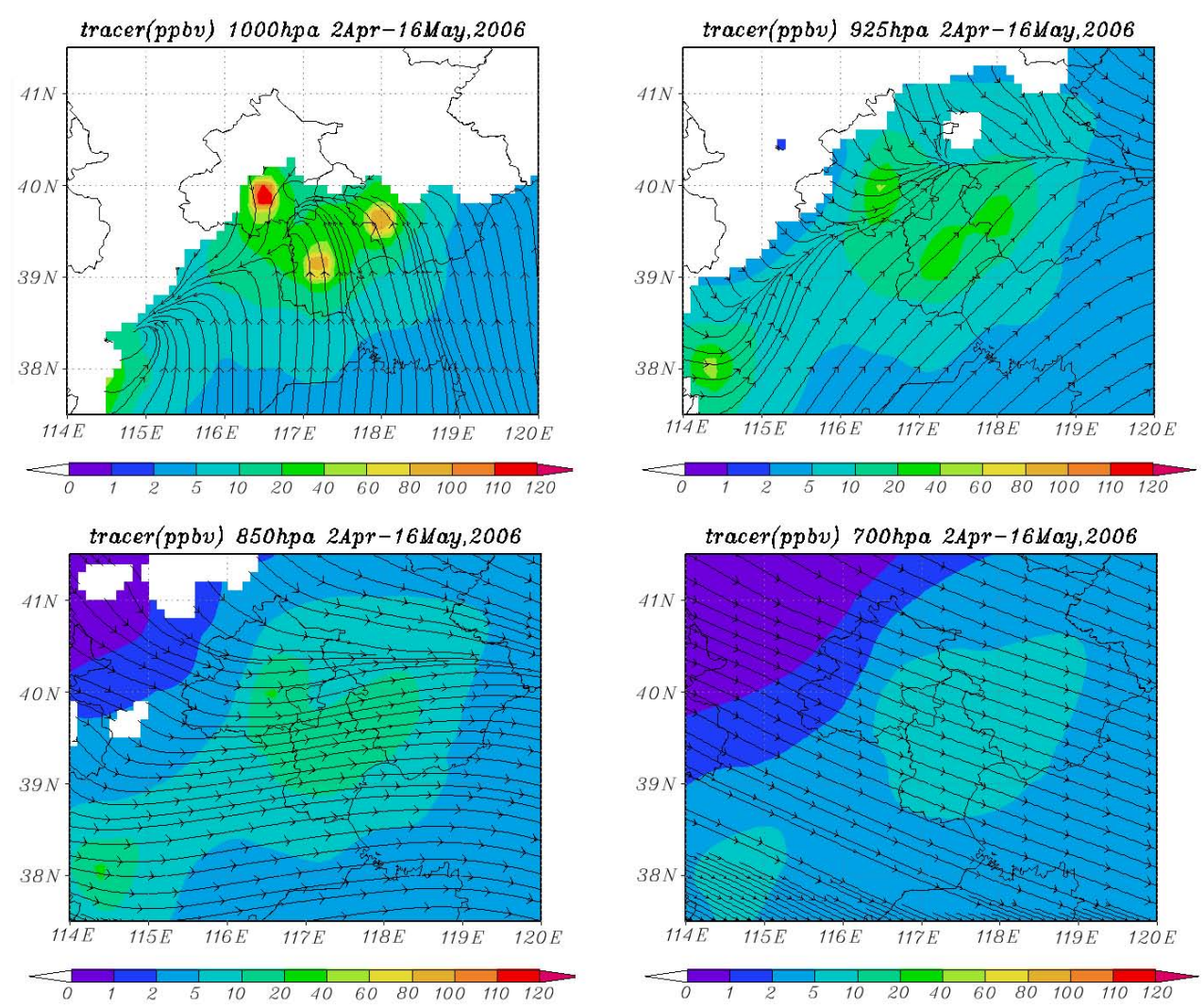

Fig. 2. Model simulated wind fields and spatial distributions of pollution tracers emitted from major urban centers of Huabei. Mountain areas are masked by blanks. The model predicts an air pollution pool over the larger Beijing, Tianjin and Tangshan area (Jing-Jin-Tang). 


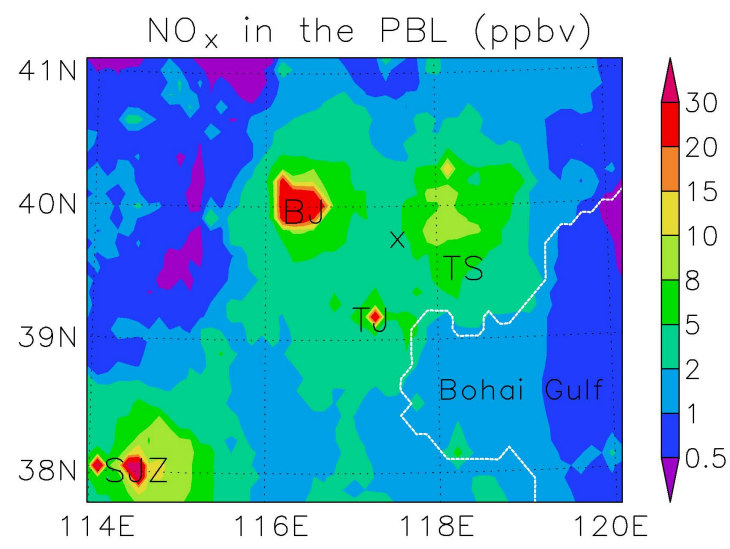

Fig. 3. RCTM simulated $\mathrm{NO}_{\mathrm{x}}$ mixing ratios in the planetary boundary layer (PBL) during IPAC-NC. The model predicts large regions with enhanced $\mathrm{NO}_{\mathrm{x}}$ around Beijing (BJ), Tianjin (TJ), Tangshan (TS) and Shijiazhuang (SJZ). The cross indicates the position of Xin'an station.

\subsection{Regional and chemical box models}

We applied a regional chemical-transport model (RCTM) (Ma et al., 2002a) with an updated high-resolution $\left(10 \times 10 \mathrm{~km}^{2}\right)$ emission inventory for the year 2003 developed by Zhao et al. (2012), and the chemical lateral boundary conditions were adopted from the EMAC global model Jöckel et al. (2006); the simulation results are presented in Fig. 3. The $\mathrm{NO}_{\mathrm{x}}$ pollution hot spots of Beijing, Tianjin, Tangshan and Shijiazhuang are clearly shown by our RCTM simulation. A qualitative comparison of model calculated and satellite measured (Ozone Monitoring Instrument; Boersma et al., 2007) tropospheric $\mathrm{NO}_{2}$ column densities (not shown) indicates that the major urban-industrial $\mathrm{NO}_{\mathrm{x}}$ sources are reasonably well represented in our emission database. Rural emissions, on the other hand, possibly from small scale industrial and agricultural activities, i.e. more difficult to capture by statistical datasets, are probably underestimated.

We used a tracer-tagging method implemented in our RCTM, as described by Ma et al. (2002c), to simulate transport and transformation of nitrogen compounds originating from different emission sources. Figure 4 presents the percentage contributions of industrial, traffic and other sources to $\mathrm{NO}_{\mathrm{x}}$ in the PBL over the central area of Huabei. The other sources refer to the emissions from civil activities and biomass burning and the inflow from outside of the Huabei model domain (about $37-42^{\circ} \mathrm{N}$ and $112-122^{\circ} \mathrm{E}$ ). Interestingly, the pollution characteristics in different areas of Huabei are quite different. For example, the atmospheres over the Beijing, Shijiazhuang and west Tianjin area are influenced predominantly by traffic emissions $(\sim 60-80 \%)$, and over the Tangshan and east Tianjin area mostly by industrial pollution $(\sim 50-70 \%)$. Note that this result may not apply to urban air quality at the surface (e.g. Tianjin city), where traffic emissions generally dominate the pollution sources.

In this study we investigate the radical chemistry and ozone production using a box model based on the NCAR Master Mechanism (Madronich and Calvert, 1989, 1990; Ma et al., 2002b), constrained by the observed mean trace gas concentrations. The model was designed explicitly to test the local photochemical equilibrium over a time scale of several minutes. During each simulation, specified physical and chemical parameters such as temperature and the mixing ratios of relatively long-lived species, such as $\mathrm{H}_{2} \mathrm{O}, \mathrm{CH}_{4}$, $\mathrm{H}_{2}, \mathrm{SO}_{2}, \mathrm{NO}, \mathrm{NO}_{2}, \mathrm{CO}, \mathrm{O}_{3}, \mathrm{CH}_{2} \mathrm{O}$ and non-methane hydrocarbons (NMHCs), were kept constant. The concentrations of $\mathrm{NO}_{2}$ were derived by scaling measured $\mathrm{NO}$ with the $\mathrm{NO}_{2} / \mathrm{NO}$ ratios derived from our RCTM (Ma et al., 2002a). The observed individual NMHC species in the field experiment were applied as described by Ma et al. (2002b). The concentrations of $\mathrm{CH}_{2} \mathrm{O}, \mathrm{CH}_{3} \mathrm{OOH}$ and $\mathrm{H}_{2} \mathrm{O}_{2}$ were not measured during our field experiment, and their values were taken from measurements in other studies (Russo et al., 2003; Shao et al., 2009). Photodissociation rate coefficients (Jvalues) were calculated with the radiation transfer model TUV (Madronich, 1987), and the daytime mean J-values for 15 April 2006 were used for model simulations at the selected altitudes. Clear sky conditions were assumed, and the mean vertical profiles of aerosol optical properties, based on our aircraft measurements (Ma et al., 2010), were used in the J-value calculations.

For this study we updated the model by taking into account heterogeneous reactions of trace gases and radicals on aerosol surfaces in the model simulations:

$\mathrm{H}_{2} \mathrm{SO}_{4} \stackrel{\text { aerosols }}{\longrightarrow}$ sulfate,

OVOC $\stackrel{\text { aerosols }}{\longrightarrow}$ OC,

$\mathrm{OH} \stackrel{\text { aerosols }}{\longrightarrow}$ products,

$\mathrm{HO}_{2} \stackrel{\text { aerosols }}{\longrightarrow}$ products,

where $\mathrm{H}_{2} \mathrm{SO}_{4}$ and OVOC are sulfuric acid and partly oxidized organic compounds in the gas-phase, and sulfate and $\mathrm{OC}$ are their products in aerosol phase. While the Reactions (R14) and (R15) represent important loss pathways of gaseous sulfuric acid and OVOC, the reactions also lead to the formation of sulfate and organic aerosols. We adopted the same values of uptake coefficients as used by Zhu et al. (2010) for the calculation of heterogeneous reaction rates.

$k_{\gamma}=\int\left[\frac{1+K_{n}}{1+0.377 K_{n}+1.33 K_{n} \cdot\left(1+K_{n}\right) / \gamma}\right] \cdot 4 \pi \cdot D_{v} \cdot r \cdot N \cdot \mathrm{d} r$,

where $k_{r}$ is the pseudo first-order rate coefficient $\left(\mathrm{s}^{-1}\right), K_{n}$ is the Knudsen number (the ratio of mean free path of condensing vapor molecules to particle radius), $\gamma$ is the uptake 
Table 1. Overview of the aircraft measurements made during IPAC-NC.

\begin{tabular}{|c|c|c|c|c|}
\hline Item & Instrument & Temporal resolution & Measurement properties & Invalid flights \\
\hline $\mathrm{SO}_{2}$ & TE43C & $80 \mathrm{~s}$ & DL: $0.1 \mathrm{ppbv}$ & RF02, \\
\hline $\mathrm{CO}$ & TE48C & $1 \mathrm{~s}$ & DL: 5 ppbv & $\mathrm{RF} 02, \mathrm{RF} 17, \mathrm{TF} 2$ \\
\hline $\mathrm{NO}_{\mathrm{x}}$ & TE42C & $10 \mathrm{~s}$ & DL: $0.1 \mathrm{ppbv}$ & RF02, RF07 \\
\hline $\mathrm{O}_{3}$ & TE49C & $20 \mathrm{~s}$ & DL: $0.1 \mathrm{ppbv}$ & RF02 \\
\hline NMHCs & Canisters & 2-4 samples flight ${ }^{-1}$ & Alkanes, alkenes, aromatics & TF2 \\
\hline $\mathrm{PM}_{10}$ & Quartz filters & $1-2$ samples flight ${ }^{-1}$ & Ions, element, EC/OC & $\mathrm{TF} 2$ \\
\hline $\mathrm{CN}$ & TSI-3020 & $1 \mathrm{~s}$ & $\mathrm{SR}:>5 \mathrm{~nm}$ & RF02, TF2 \\
\hline$N_{1, \text { aer }}$ & TSI-EEPS-3090 & $1 \mathrm{~s}$ & SR: $5.6-560 \mathrm{~nm}, 32 \mathrm{bins}$ & RF08-17, TF1-2 \\
\hline$N_{2}$, aer & TSI-APS-3310A & $30 \mathrm{~s}$ & SR: $0.47-30 \mu \mathrm{m}, 58 \mathrm{bins}$ & TF2 \\
\hline$N_{3}$, aer & PCASP-100X & $1 \mathrm{~s}$ & SR: $0.1-3.0 \mu \mathrm{m}, 15$ bins & RF04 \\
\hline$N_{\text {cld }}$ & FSSP-100 & $1 \mathrm{~s}$ & SR: $2-47 \mu \mathrm{m}, 15$ bins & RF04 \\
\hline$T$ & EMM-01 & $1 \mathrm{~s}$ & Accuracy: $0.008^{\circ} \mathrm{C}$ & RF02 \\
\hline$T_{\mathrm{d}}$ & DP3-D-SH & $1 \mathrm{~s}$ & Accuracy: $0.1^{\circ} \mathrm{C}$ & RF02 \\
\hline GPS & GPS-Global Water & $1 \mathrm{~s}$ & & \\
\hline
\end{tabular}

$N_{\mathrm{i} \text {, aer }}$ and $N_{\mathrm{cld}}$ : aerosol and cloud number concentrations, respectively; DL: detect limit; SR: size range. See Table 2 for flight information.

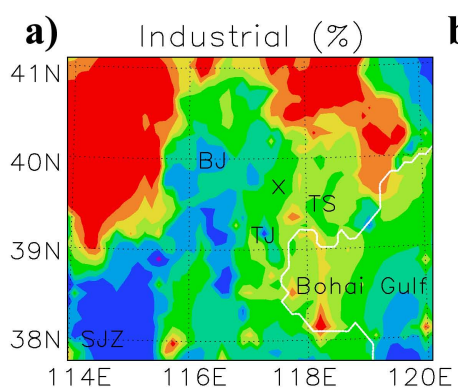

b)

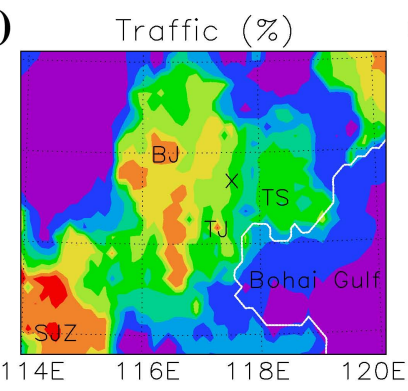

c)

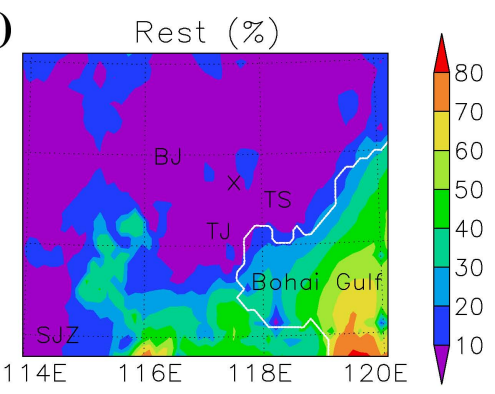

Fig. 4. Percentage contributions from industrial, traffic and other sources to the $\mathrm{NO}_{\mathrm{x}}$ in the $\mathrm{PBL}$ as estimated with a tracer-tagging method in our RCTM. Labels are the same as in Fig. 3.

coefficient of a species, $D_{v}$ is the diffusion coefficient of the condensing vapor $\left(\mathrm{cm}^{2} \mathrm{~s}^{-1}\right), r$ and $N$ represent the particle radius $(\mathrm{cm})$ and number concentration $\left(\mathrm{cm}^{-3}\right)$ with a radius between $r$ and $r+\mathrm{d} r$. All organic carbonyls, alcohols and peroxides, and acids in the model were assumed to have the same reactive uptake coefficients as $\mathrm{CH}_{2} \mathrm{O}, \mathrm{CH}_{3} \mathrm{OOH}$ and $\mathrm{CH}_{3} \mathrm{COOH}$, respectively. The chemical rate equations are integrated forward with a Gear-type solver. Simulations were performed for $12 \mathrm{~h}$ and the results of the last hour are analyzed in this study. Since most long-lived species were fixed, the concentrations of radicals and other organic products could attain a steady state during the last few hours with changes less than $1 \%$.

\subsection{Measurement platforms and instruments}

The principal measurement platforms of IPAC-NC included a twin-engine YUN-12 aircraft operated from Tianjin International Airport and two ground stations, one located at $39.88^{\circ} \mathrm{N}, 116.47^{\circ} \mathrm{E}$ on the campus of the Beijing University of Technology (Beigongda station), and the other at $39.73^{\circ} \mathrm{N}, 117.53^{\circ} \mathrm{E}$ in the Xin' an weather modification sta- tion of the Baodi County of Tianjin Municipality (Xin'an station, previously referred as Baodi station by Ma et al., 2010). Beigongda is an urban site in the southeast of Beijing, at about $9 \mathrm{~km}$ distance from Tian-An-Men Square (the center point of the city) and $1 \mathrm{~km}$ (inside) from the East 4th Ring Road, and the instruments were located on the roof of an 11story building. Xin'an is a rural site in the center of Jing-JinTang, about $85 \mathrm{~km}, 70 \mathrm{~km}$, and $105 \mathrm{~km}$ from Beijing, Tianjin, and Tangshan, respectively, and the instruments were located on the roof of a single-story building. The Xin'an site is surrounded by agricultural fields, about $1 \mathrm{~km}$ from the small town. Trace gases (including $\mathrm{SO}_{2}, \mathrm{NO}_{\mathrm{x}}, \mathrm{CO}, \mathrm{NMHCs}$ and $\mathrm{O}_{3}$ ) and aerosols (mass and chemical composition of $\mathrm{PM}_{2.5}$ ) were measured at the two stations. In addition, the particle size distributions and the aerosol scattering coefficients as a function of relative humidity were measured at the Xin'an site (Pan et al., 2009; Ma et al., 2010).

Table 1 presents a summary of the instruments mounted on board the aircraft to measure trace gases, aerosols, clouds and meteorological parameters (Wang et al., 2008; Ma et al., 2010). A FEP-Teflon tube was used to introduce the ambient air from below the fuselage into the aircraft cabin for 
gas analysis. $\mathrm{O}_{3}$ was measured by a UV-absorption analyzer (TECO Model 49, USA) with a response time of $20 \mathrm{~s}$. Nitrogen oxides were monitored by an $\mathrm{O}_{3}$-chemiluminescence NO-NO ${ }_{x}$ analyzer (TECO Model 42C-Tl, USA). The analyzer measures the chemiluminescence induced by the reaction between $\mathrm{NO}$ and $\mathrm{O}_{3}$, the intensity of which is proportional to the $\mathrm{NO}$ concentration. $\mathrm{NO}_{\mathrm{x}}$ measurements are approximated using the thermal reduction of $\mathrm{NO}_{2}$ to $\mathrm{NO}$ by a heated $\left(320^{\circ} \mathrm{C}\right)$ molybdenum converter. The $10 \mathrm{~s}$ duty cycle of the TE42C alternates between $\mathrm{NO}$ and $\mathrm{NO}_{\mathrm{x}}$ measurements. The difference between the two measurements allows the two continuous signals of $\mathrm{NO}$ and $\mathrm{NO}_{\mathrm{x}}$. Data are produced at $1 \mathrm{~Hz}$, although the readings of $\mathrm{NO}$ and $\mathrm{NO}_{\mathrm{x}}$ are only updated every $10 \mathrm{~s}$. Note that the TE42C $\mathrm{NO}_{2}$ conversion technique is non-selective (e.g. by comparison to photolytic conversion), and that other $\mathrm{NO}_{\mathrm{y}}$ compounds can interfere (positive bias). Therefore, the reactive nitrogen species detected as $\mathrm{NO}_{\mathrm{x}}$ with this analyzer probably include some $\mathrm{NO}_{\mathrm{y}}$ (e.g. nitric acid and organic nitrates) and are denoted as $\mathrm{NO}_{\mathrm{x}}^{*}$, following Hatakeyama et al. (2005). $\mathrm{SO}_{2}$ was monitored by a UV pulse fluorescence analyzer (TECO Model 43C-TL, USA) with a response time of about $80 \mathrm{~s}$. CO was monitored by a gas filter correlation analyzer (TECO Model 48C, USA) with a response time of about $1 \mathrm{~s}$. All instruments were aligned with zero air before and after entering the sampling areas during every flight. Since the CO analyzer on board the aircraft needed a relatively long period for stabilization during each flight, only the second half of the $\mathrm{CO}$ data could be used for analyses. The chemistry instruments on board the aircraft were turned on about 15 min after taking off and switched off about $15 \mathrm{~min}$ before landing. NMHCs sampling was done using 2-4 canisters per flight and each canister was typically filled in 10-20 min. After the flight, the samplers were directly sent to the State Joint Key Laboratory of Environmental Simulation and Pollution at Peking University for chemical analyses (Shao et al., 2009). NMHC species were detected using a cryogenic pre-concentrator (Entech Instrument 7100A, SimiValley, CA) and a gas chromatograph (GC, Hewlett Packard 6890) equipped with two columns and two detectors. The $\mathrm{C} 2-\mathrm{C} 4$ alkanes and alkenes were separated on a non-polar capillary column (HP-1, J\&W Scientific) and quantified with a flame ionization detector (FID). The C5C12 hydrocarbons were separated on a semi-polar column (DB-624, J\&W Scientific) and quantified using a quadrupole mass spectrometer (MS, Hewlett Packard, 5973). Detailed descriptions of the GC/FID-GC/MS analysis method can be found in Liu et al. $(2005,2008)$.

Ground and aircraft aerosol filter sampling as well as the chemical analyses were conducted using the methods as described in previous studies (Pan et al., 2009; Ma et al., 2010). Condensation nuclei $(\mathrm{CN})$ concentrations were measured at a frequency of $1 \mathrm{~Hz}$ with a condensation particle counter (TSI3020, USA), which detects sub-micrometer particles larger than $5 \mathrm{~nm}$ diameter. Ultrafine particle concentrations with diameters of 5.6-560 nm were measured with an Engine Ex- haust Particle Sizer Spectrometer (EEPS) model 3090 (TSI3090, USA) at $1 \mathrm{~Hz}$ frequency. A diversion dome was mounted on the belly of the fuselage to introduce ambient air into the sampling tubes, and the sample air was introduced into the aircraft cabin through stainless steel and conductive carbon tubes. The sampling flow rates were $21 \mathrm{~min}^{-1}$ for $\mathrm{CN}$ and $101 \mathrm{~min}^{-1}$ for the EEPS. Accumulation mode aerosols of 0.1-3.0 $\mu \mathrm{m}$ diameter were measured with a Particle Cavity Aerosol Spectrometer Probe (PCASP-100X, PMS, USA), and cloud droplet number concentrations of $2-47 \mu \mathrm{m}$ diameter were determined using a Forward Scattering Spectrometer Probe (FSSP-100, PMS, USA). These two PMS probes were installed externally on the belly of the aircraft to measure the particle and droplet size distribution at ambient humidity. Temperature, relative humidity, and geographical information (latitude, longitude, and altitude) were measured continuously with a thermometer (EMM-01), a dew-point hydrometer (DP3-D-SH, Tempcontrol, NL), and a global positioning system (GPS, Global Water, USA). Detailed descriptions of the instruments and aircraft sampling system can be found in Wang et al. (2008) and Ma et al. (2010).

\subsection{Aircraft flight time and areas}

Table 2 presents an overview of the flights performed in IPAC-NC. The aircraft transferred from the Changzhou city of Jiangsu Province in southern China to the Tianjin airport on 2 April 2006, and back to Changzhou on 16 May 2006. Most instruments were on board during the transfer flights (TF), and thus the measurement data obtained over the Huabei region on these two days can also be used for this study. Seventeen research flights (RF) were performed during the campaign, including eight under clear-sky conditions (described as hazy for some days), eight under cloudy conditions, and one during a dust storm (RF06). Several flight patterns were designed and implemented based on a combination of research objectives, weather conditions, and air traffic control regulations. The flight altitude ranged up to $3500 \mathrm{~m}$, the cruising velocity was generally $\sim 200 \mathrm{~km} \mathrm{~h}^{-1}$, and the flight duration was typically around $4-5 \mathrm{~h}$. Figure 5 shows all flight tracks individually, and Fig. 6 presents their spatial coverage by combining all research fight tracks in one overview. The aircraft measurements took place over the Tianjin and Tangshan areas and the downwind region, located within the above described air pollution pool.

\section{Results and discussion}

Here we present our analytical results, including statistics and model calculations based on the data obtained during the campaign, focusing on the general chemical characteristics over the region. Detailed episode analyses, e.g. the influence of local meteorological conditions on the measurement results, will be presented in dedicated follow-up papers. 
Table 2. Overview of aircraft flights performed during IPAC-NC.

\begin{tabular}{|c|c|c|c|c|c|c|}
\hline Flight & $\begin{array}{l}\text { Flight } \\
\text { description }\end{array}$ & $\begin{array}{l}\text { Flight } \\
\text { route pattern }\end{array}$ & $\begin{array}{l}\text { Date in } \\
2006\end{array}$ & $\begin{array}{l}\text { Take off-Landing } \\
\text { Time (UTC) }\end{array}$ & $\begin{array}{l}\text { Flight } \\
\text { altitude }(\mathrm{m})\end{array}$ & $\begin{array}{l}\text { Weather } \\
\text { condition }\end{array}$ \\
\hline TF1 & Changzhou - Tianjin & Line & 2 April & $03: 30-07: 58$ & 2500 & Hazy \\
\hline RF01 & Huangzhuang & Circle & 9 April & $01: 54-05: 50$ & $2800-400$ & Cloudy \\
\hline RF02 & Bohai (over sea) & Circle & 12 April & $05: 17-10: 20$ & $2800-400$ & Hazy \\
\hline RF03 & Baodi - Jinghai - Tanggu & Line & 13 April & $11: 25-14: 34$ & $2500-1000$ & Clear \\
\hline RF04 & Guojuzi-Haitiancun (over sea) & Line & 15 April & $11: 51-14: 43$ & $2000-1000$ & Hazy \\
\hline RF05 & Tianjin-Tangshan region & Area & 16 April & $01: 52-05: 46$ & $2300-1700$ & Cloudy \\
\hline RF06 & Bohai (over sea) & Circle & 17 April & $01: 56-06: 28$ & $2800-400$ & Dusty \\
\hline RF07 & Tianjin-Tangshan region & Square & 18 April & $01: 58-06: 31$ & $2500-1000$ & Cloudy \\
\hline RF08 & Jixian - Qingxian & Line & 22 April & $02: 10-06: 03$ & $2500-500$ & Clear \\
\hline RF09 & Tianjin-Tangshan region & Area & 26 April & $01: 47-06: 52$ & $2700-1000$ & Cloudy \\
\hline RF10 & Guojuzi-Haitiancun (over sea) & Line & 1 May & $01: 35-06: 16$ & $2000-500$ & Hazy \\
\hline RF11 & Yutian - Beidagang & Line & 3 May & $05: 19-08: 28$ & $3000-500$ & Hazy \\
\hline RF12 & Jixian - Qingxian - Ninghe & Line & 4 May & $01: 48-06: 44$ & $2500-500$ & Cloudy \\
\hline RF13 & Tianjin North region & Area & 7 May & $04: 45-07: 04$ & $3000-500$ & Hazy \\
\hline RF14 & Jixian - Qingxian (North) & Line & 9 May & 08:14-11:04 & $3100-2400$ & Cloudy \\
\hline RF15 & Jixian - Qingxian (South) & Line & 11 May & $09: 24-10: 54$ & $3100-1200$ & Cloudy \\
\hline RF16 & Tianjin-Tangshan region & Area & 12 May & $04: 21-07: 50$ & $2000-1500$ & Cloudy \\
\hline RF17 & Tianjin-Tangshan region & Area & 13 May & 07:02-09:02 & $2700-600$ & Clear \\
\hline $\mathrm{TF} 2$ & Tianjin - Changzhou & Line & 16 May & $01: 53-05: 34$ & 3000 & Clear \\
\hline
\end{tabular}

Beijing Time is (UTC+8).

\subsection{Urban and regional pollution observed on the ground}

Figure 7 shows average diurnal variations of trace gases measured at the Beigongda (urban) and Xin'an (rural) stations. Since $\mathrm{NO}_{\mathrm{x}}$ measurements might be influenced by $\mathrm{NO}_{\mathrm{y}}(\mathrm{PAN}$, $\mathrm{HNO}_{3}, \mathrm{RNO}_{2}$, etc.), at least for the rural site, we use $\mathrm{NO}_{2}^{*}$ and $\mathrm{NO}_{\mathrm{x}}^{*}$ to denote measured $\mathrm{NO}_{2}$ and $\mathrm{NO}_{\mathrm{x}}$, respectively, indicating that these measurements probably represent an upper limit. High concentrations of primary pollutants $\mathrm{SO}_{2}$, $\mathrm{NO}, \mathrm{NO}_{2}^{*}$ and $\mathrm{CO}$ were observed at both the urban and rural sites. The pollution levels of $\mathrm{SO}_{2}$ and $\mathrm{NO}_{\mathrm{x}}^{*}$ were higher at the Beigongda site than at the Xin'an site, while the levels of $\mathrm{CO}$ were similar (around 1-2 ppmv). $\mathrm{CO}$ has a lifetime of about 1-2 months, much longer than $\mathrm{SO}_{2}$ and $\mathrm{NO}_{\mathrm{x}}$ (about one day). Compared to traffic and industrial activities, biomass burning produces relatively more $\mathrm{CO}$ than the other pollutants like $\mathrm{NO}_{\mathrm{x}}$ due to inefficient combustion (Crutzen and Andreae, 1990), and it is more widespread across the rural areas, contributing nearly $20 \%$ to the annual total CO emission in Huabei (Zhao et al., 2012). Comparing the 90th percentiles of $\mathrm{CO}$ at the two sites, it is expected that $\mathrm{CO}$ at Xin'an is more frequently affected by plume episodes from industrial and biomass burning sources. During the campaign, the Xin'an site was also influenced by air masses from the industrial areas of Tangshan, Beijing and Tianjin (Pan et al., 2009). Biomass burning might also lead to enhanced CO at the Xin'an site. Lin et al. (2008) observed an unexpected increase of $\mathrm{CO}$ at Guocheng, a rural site $110 \mathrm{~km}$ southwest of Beijing in May, June and October, and argued that biomass burning is a major source of $\mathrm{CO}$ in the agricultural areas of the region.

The diurnal cycles of low-reactive primary pollutants are affected by both the source distribution and PBL dynamics. As shown in Fig. 7, the $\mathrm{NO}, \mathrm{NO}_{2}^{*}$ and $\mathrm{CO}$ at Beigongda and Xin'an stations had a similar diurnal pattern, with a maximum in the early morning and a minimum in the afternoon. These pollutants have strong surface sources and tend to accumulate during nighttime when the PBL is shallow, while being more diluted during daytime when the PBL deepens. There was a sharp peak of NO in the early morning at the two sites, probably related to rush hour emissions, subsequent $\mathrm{PBL}$ deepening and $\mathrm{NO}_{2}$ photolysis. Due to the reaction of $\mathrm{NO}$ with $\mathrm{O}_{3}, \mathrm{NO}_{\mathrm{x}}$ exists mainly in the form of $\mathrm{NO}_{2}$ during nighttime. It should be noted that during several days, $\mathrm{NO}$ was very low when $\mathrm{O}_{3}$ was very high, and vice versa. Since average values are presented, we may expect significant nighttime $\mathrm{NO}$ simultaneously with $\mathrm{O}_{3}$. $\mathrm{NO}$ can be produced rapidly by the photodissociation of $\mathrm{NO}_{2}$ in the early morning at sunrise. In the afternoon, $\mathrm{NO}$ decreases due to the reaction with increasing $\mathrm{O}_{3}$ formed in photochemical smog. Note that such an NO early morning peak was also observed in other rural and urban sites in China, e.g. at the Shangdianzi regional background station of Huabei (Lin et al., 2008) and at an urban station in Shanghai (Geng et al., 2008). Interestingly, the diurnal cycles of $\mathrm{SO}_{2}$ at Beigongda and Xin' an stations were similar, with higher concentrations appearing during daytime, in contrast to $\mathrm{NO}, \mathrm{NO}_{2}^{*}$ and $\mathrm{CO}$. This was also observed at the Gucheng and Shangdianzi sites in Huabei (Lin et al., 2008, 2009). Different from other 

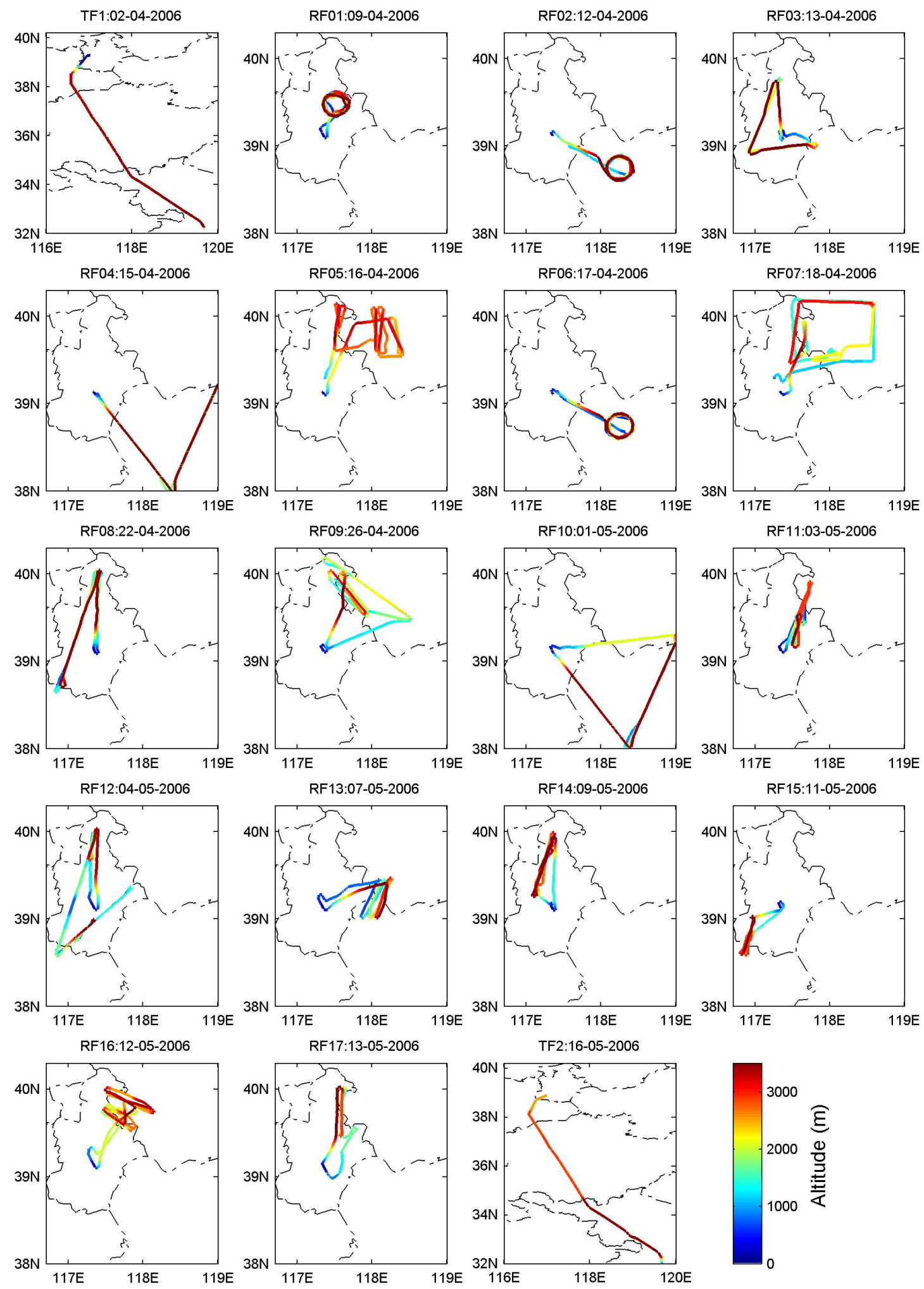

Fig. 5. YUN-12 individual flight tracks during IPAC-NC colored by altitude. Two transfer flights and 17 research flights were performed from 2 April to 16 May 2006. 


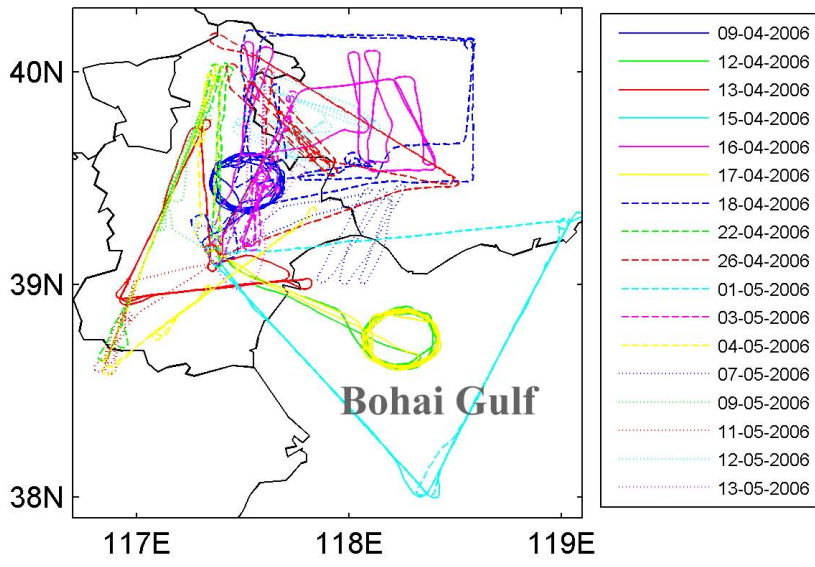

Fig. 6. Superposition of 17 research flight tracks during IPAC-NC. The majority of flights were performed within the core area of the air pollution pool.

primary pollutants $\left(\mathrm{NO}_{\mathrm{x}}\right.$ and $\left.\mathrm{CO}\right)$, the emissions of $\mathrm{SO}_{2}$ are dominated by coal burning in industrial activities, which contributes nearly $90 \%$ of the total $\mathrm{SO}_{2}$ emission in Huabei (Zhao et al., 2012). The plume rise by some stacks, especially of power plants, can be high enough to release the pollutants well above the stable PBL height at night. During daytime, an increase in the mixing layer brings overhead plumes to the ground, thus enhancing the $\mathrm{SO}_{2}$ concentrations as observed at these stations. A layer of enhanced $\mathrm{SO}_{2}$ at altitudes of around $500 \mathrm{~m}$ was observed by aircraft in IPAC-NC as presented below (see Sect. 3.3).

The diurnal cycles of secondary pollutants are mainly controlled by photochemical processes. As shown in Fig. 7, the daily $\mathrm{O}_{3}$ variation at Beigongda and Xin' an stations are typical for photochemical pollution. Hourly mean $\mathrm{O}_{3}$ concentrations at the two sites were similar, with maximum values around $65 \mathrm{ppbv}$ in the afternoon. These values are more than $10 \mathrm{ppbv}$ higher than the maximum hourly mean $\mathrm{O}_{3}$ concentrations observed in Xianghe, a rural site between Beigongda and Xin'an stations, in March 2005 (Li et al., 2007). In the afternoon, the $\mathrm{O}_{3}$ variability was larger in Beigongda than in Xin'an, indicating greater source dynamics and photochemistry in the urban atmosphere. The chemical cycle of $\mathrm{NO}, \mathrm{NO}_{2}$ and $\mathrm{O}_{3}$ during sunlight is very rapid (1-2 min), and thus part of the $\mathrm{O}_{3}$ formed via the reaction of $\mathrm{NO}$ with $\mathrm{HO}_{2}$ and $\mathrm{RO}_{2}$ can exist in the form of $\mathrm{NO}_{2}$ when NO levels are very high. Therefore, total oxidant $\left(\mathrm{O}_{\mathrm{x}} \equiv \mathrm{O}_{3}+\mathrm{NO}_{2}\right)$ has often been used to characterize photochemical oxidant levels, especially in the urban and suburban areas (e.g. Lu et al., 2010). We calculated $\mathrm{NO}_{2}$ using the chemical box model (see Sect. 2.2), constrained by measured concentrations of ozone and its precursors including NO. The average daytime $\mathrm{NO}_{2} / \mathrm{NO}_{\mathrm{x}}$ ratios are estimated to be 0.74 based on our measurements and 0.72 by modeling at Beigongda (urban site), and 0.75 based on our measurements and 0.70 by modeling at Xin'an (rural site). By comparing calculated results with measurements, we estimate that about $5 \%$ of $\mathrm{NO}_{\mathrm{x}}^{*}$ at Beigongda and $15 \%$ of $\mathrm{NO}_{\mathrm{x}}^{*}$ at Xin' an might be affected by the interference of other $\mathrm{NO}_{\mathrm{y}}$ species. Therefore, the modeled $\mathrm{NO}_{2}$ values are used for the calculation of $\mathrm{O}_{\mathrm{x}}$ in this study. Figure 7 shows that the observed $\mathrm{O}_{\mathrm{x}}$ concentrations at Beigongda were higher than they were at Xin'an (maximum hourly mean mixing ratio $91 \mathrm{ppbv}$ vs. $80 \mathrm{ppbv}$ ), and their diurnal variability was smaller compared to $\mathrm{O}_{3}$ at Beigongda. The difference between the maximum and minimum hourly mean $\mathrm{O}_{3}$ concentrations at the two sites was nearly the same (50-51 ppbv). However, the difference between the maximum and minimum hourly mean $\mathrm{O}_{\mathrm{x}}$ concentration was smaller in Beigongda (32 ppbv) than in Xin'an (42 ppbv), both much lower than the $\mathrm{O}_{3}$ difference at the two sites. Scatter plots of measurement data show that observed $\mathrm{O}_{3}$ and $\mathrm{NO}_{2}^{*}$ were anti-correlated at the Beigongda and Xin' an stations (not shown). This indicates that $\mathrm{O}_{3}$ production at the two sites was generally $\mathrm{NO}_{\mathrm{x}}$-saturated and limited more strongly by a relatively low $\mathrm{OH}$ recycling efficiency, with increasing $\mathrm{NO}_{2}$ at the urban site compared to the rural site.

During the IPAC-NC campaign air samples were obtained at the Beigongda and Xin' an sites for NMHC analyses, and 55 individual species were quantitatively identified (Cheng and Wang, 2010). We calculated the reactivity of each NMHC species, $L_{\mathrm{OH}}$, using measured concentration times the reaction rate constant of such species with $\mathrm{OH}$ at $298 \mathrm{~K}$ following Atkinson and Arey (2003). Figure 8a and b present measured mixing ratios and calculated reactivity of alkanes, alkenes and aromatics at Beigongda and Xin' an. The average mixing ratio of NMHCs was $118 \mathrm{ppbv}$ at the urban site and $55 \mathrm{ppbv}$ at the rural site, and their reactivity was $31 \mathrm{~s}^{-1}$ and $13 \mathrm{~s}^{-1}$ at the urban and rural sites, respectively, indicating higher NMHC activity in the urban area than in the rural area. The total NMHC mixing ratio and reactivity during IPAC$\mathrm{NC}$ are much higher than reported by Shao et al. (2009) for Beijing and its suburban area for the summer period. Higher $L_{\mathrm{OH}}$ values in urban Beijing $\left(51 \mathrm{~s}^{-1}\right)$ and the Huabei regional background station $\left(16 \mathrm{~s}^{-1}\right)$ have been estimated by Xu et al. (2011) for summertime. As shown in Fig. 8a, aromatics contributed greatly to the total NMHC mixing ratios at both urban and rural sites. With respect to the reactivity with $\mathrm{OH}$, however, alkenes made a comparable contribution (11 vs. $\left.13 \mathrm{~s}^{-1}\right)$ at the urban site, and even larger ( 7 vs. $\left.5 \mathrm{~s}^{-1}\right)$ at the rural site, compared to aromatics (Fig. 8b). Figure 8c shows the $L_{\mathrm{OH}}$ and chemical lifetime, $\tau_{\mathrm{NMHC}}$, of individual NMHC species measured at the Beigongda and Xin'an sites during IPAC-NC. Only the species with $L_{\mathrm{OH}}>0.2 \mathrm{~s}^{-1}$ at the urban site and $L_{\mathrm{OH}}>0.1 \mathrm{~s}^{-1}$ at the rural site are presented. The top five NMHC species that contributed most to the total reactivity are $\mathrm{m}, \mathrm{p}$-xylene, toluene, $\mathrm{t}$-2-hexene, ß-pinene and 1,3,5-trimethylbenzene at the urban site, and 1,3,5-trimethylbenzene, toluene, 2-m-2-butene, m,p-xylene and propylene at the rural site. Presumably, the species 
a)

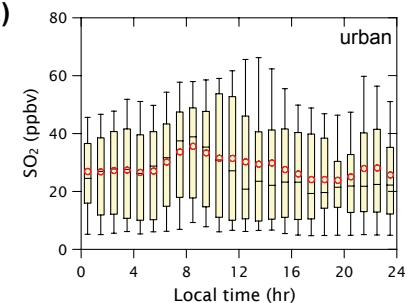

b)

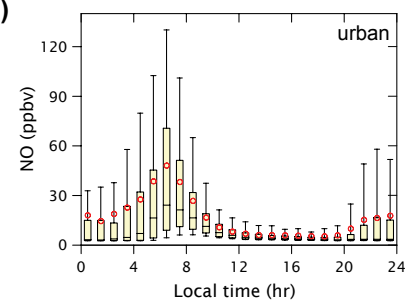

c)

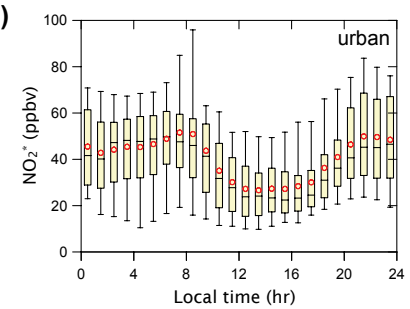

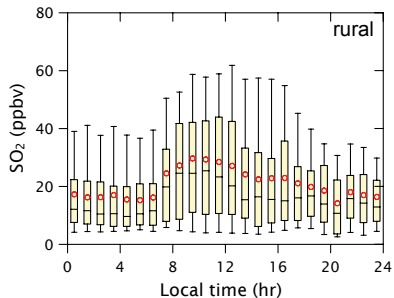

d)
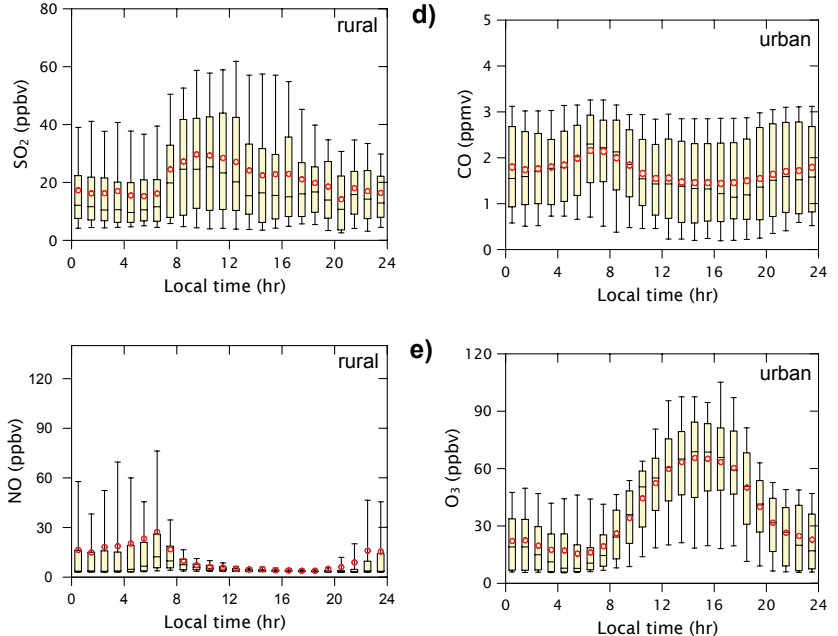

e)
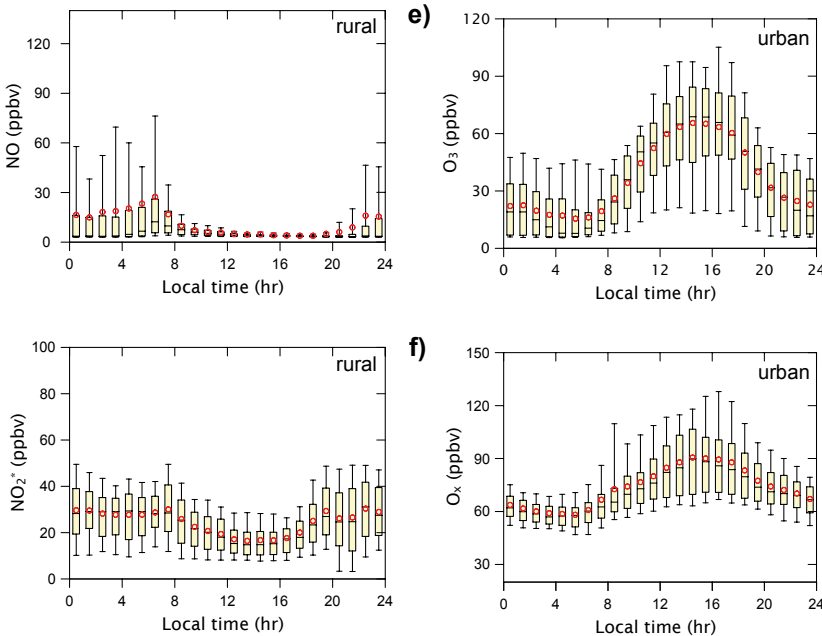

f)

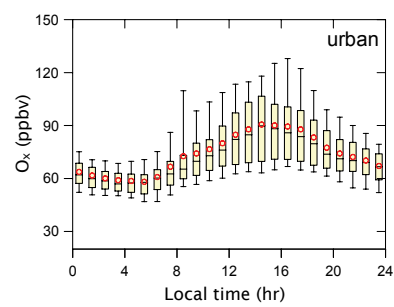

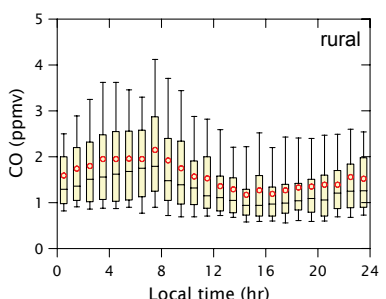

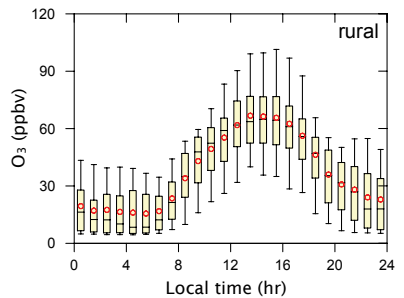

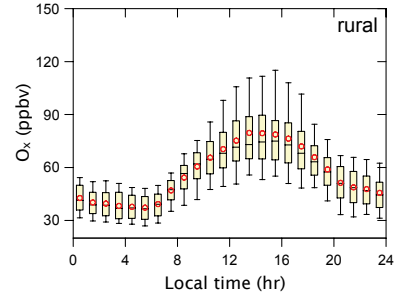

Fig. 7. Diurnal cycles of (a) $\mathrm{SO}_{2}$, (b) $\mathrm{NO}$, (c) $\mathrm{NO}_{2}^{*}$, (d) $\mathrm{CO}$, (e) $\mathrm{O}_{3}$, and (f) $\mathrm{O}_{\mathrm{x}}$ at the Beigongda (urban) and Xin'an (rural) sites during IPAC-NC. Lower (upper) error bars and yellow boxes are 10th (90th) and 25th (75th) percentiles of the data grouped in one-hour intervals, respectively. Hyphens inside the boxes are the medians and red circles the mean values.

with $\tau_{\mathrm{NMHC}}$ less than $1 \mathrm{~h}$ (e.g. 2-m-2-butene, t-2-butene, $\mathrm{t}$ 2 -petene and B-pinene) predominantly originate from local sources at both urban and rural sites. Pollution transport, e.g. from Beijing, Tianjin and Tangshan, might have a large influence on the species with $\tau_{\mathrm{NMHC}}$ larger than $2 \mathrm{~h}$ (e.g. toluene, $\mathrm{m}, \mathrm{p}$-xylene, benzene, ethylbenzene and styrene) measured at the Xin'an site.

\subsection{Widespread air pollution in the lower atmosphere}

Figure 9 shows the spatial distributions of the major gaseous air pollutants measured by aircraft below $1.5 \mathrm{~km}$ altitude (representative of the PBL during daytime) and above $1.5 \mathrm{~km}$ (representative of the lower FT). Widespread high $\mathrm{SO}_{2}$ mixing ratios were observed, typically $20-40 \mathrm{ppbv}$ below $1.5 \mathrm{~km}$ and $10-30 \mathrm{ppbv}$ aloft. Over the highly polluted area near Tianjin, $\mathrm{SO}_{2}$ even reached up to $60-100 \mathrm{ppbv}$ in the PBL, much higher than at the surface in Xin'an (Fig. 7). These high $\mathrm{SO}_{2}$ levels indicate strong and elevated industrial emission sources across the region. The $\mathrm{SO}_{2}$ levels observed in this study are a few times higher than measured over northeastern China in April 2005 and an order of magnitude higher than over the northeastern United States (Dickerson et al., 2007). Contrary to $\mathrm{SO}_{2}, \mathrm{CO}$ in the PBL was lower aloft than at the surface, indicating stronger surface $\mathrm{CO}$ sources than the elevated industrial stacks. Nevertheless, high CO mixing ratios around $1 \mathrm{ppmv}$ were also observed within the pollution pool during some flights.

NO was typically a few ppbv during all flights below and above $1.5 \mathrm{~km}$ altitude. As shown in Fig. 9, relatively low NO $(<1 \mathrm{ppbv})$ was observed along the circular flight path of RF01 over a rural area in Tianjin (near the Xin'an station) on 9 April 2006 (see Table 2 and Fig. 5 for flight information). Higher NO mixing ratios (1-2 ppbv) were observed during another circular flight, RF06, over the Bohai Gulf on 17 April 2006. Heavily clouded conditions were encountered on 9 April 2006, with both the cloud fraction and the liquid water content being highest during the campaign (Ma et al., 2010). A severe dust storm episode was observed on 17 April 2006 (Wang et al., 2008). The combined cloud and dust conditions resulted in a remarkably strong decrease in the photolysis rate of $\mathrm{NO}_{2}$ and thus a lower $\mathrm{NO} / \mathrm{NO}_{2}$ ratio in the PBL.

Although the aircraft $\mathrm{NO}_{\mathrm{x}}^{*}$ measurements are likely to include some nitric acid and organic nitrates, it may be used as an indicator of the $\mathrm{NO}_{\mathrm{x}}$ pollution level over the region investigated during IPAC-NC. The $\mathrm{NO}_{\mathrm{x}}^{*}$ levels during the campaign were generally $10-20 \mathrm{ppbv}$ below $1.5 \mathrm{~km}$ altitude and 2-10 ppbv aloft. Similar to $\mathrm{SO}_{2}$ and $\mathrm{CO}$, highest $\mathrm{NO}_{\mathrm{x}}^{*}$ concentrations were observed in the highly polluted area, with maximum mixing ratios up to $30-50$ ppbv. These very high 
a)

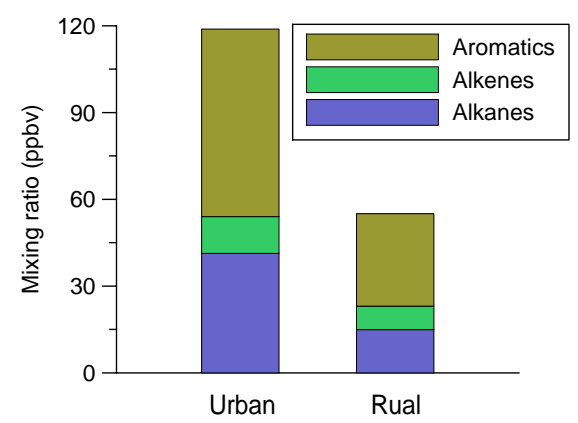

b)

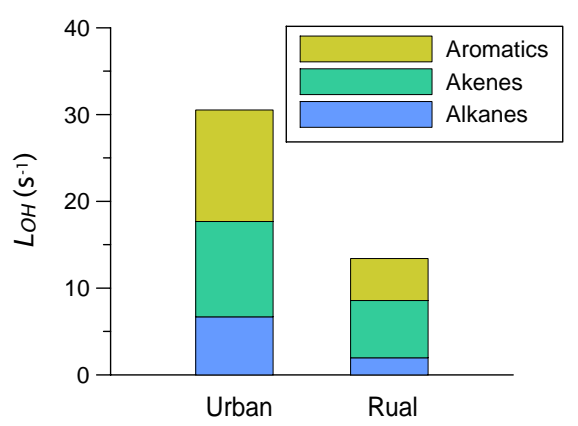

c)

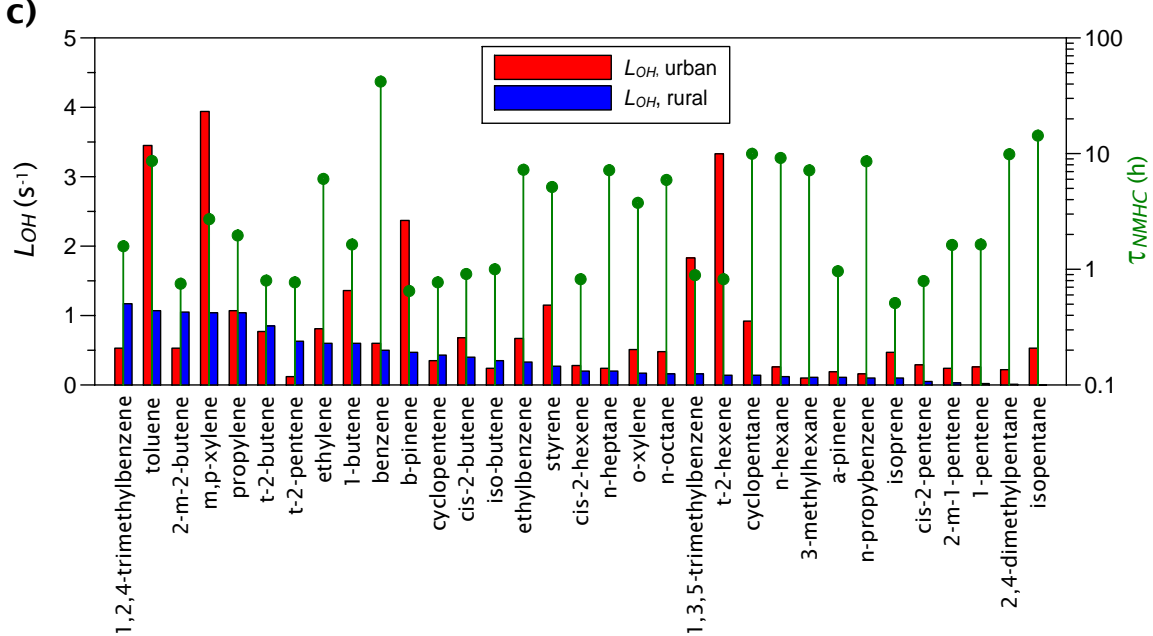

Fig. 8. Measured mixing ratios of (a) alkanes, alkenes and aromatics, (b) calculated reactivity, $L_{\mathrm{OH}}$, of alkanes, alkenes and aromatics, and (c) $L_{\mathrm{OH}}$ and chemical lifetime, $\tau_{\mathrm{NMHC}}$, of individual $\mathrm{NMHC}$ species at the Beigongda (urban) and Xin'an (rural) sites during IPAC-NC.

$\mathrm{NO}_{\mathrm{x}}^{*}$ levels corroborate the location of the pollution pool in the lower atmosphere. With respect to pollution levels over the Bohai Gulf, the $\mathrm{SO}_{2}$ and $\mathrm{NO}_{\mathrm{x}}$ concentrations observed in this study are comparable to those observed in March 2002 by Hatakeyama et al. (2005). The emission rates of these pollutants in the Huabei region may nevertheless have increased strongly from 2002 to 2006 (Zhang et al., 2009b; Zhao et al., 2012). Since the number of flights was rather small over the Bohai Gulf in both campaigns, the measurement dataset does not suffice to derive emission trends. Although the observed $\mathrm{O}_{3}$ is expected to have been primarily produced from the photochemical oxidation of CO and VOCs, catalyzed by $\mathrm{NO}_{\mathrm{x}}$, during spring stratospheric intrusions may contribute to tropospheric ozone (Hocking et al., 2007). The mixing ratios of $\mathrm{O}_{3}$ were typically $30-50 \mathrm{ppbv}$ during the campaign. The highest $\mathrm{O}_{3}$ mixing ratios of $60-70 \mathrm{ppbv}$ were observed in the severely polluted area.

\subsection{Vertical profiles}

Figure 10 presents the vertical profiles of trace gases measured during IPAC-NC. Although strongly enhanced concen- trations were found in a few plumes, the pollutants were typically more homogeneously distributed with increasing altitude. A decreasing tendency of $\mathrm{NO}, \mathrm{NO}_{\mathrm{x}}^{*}$ and $\mathrm{CO}$ with increasing altitude is evident. The vertical profile of $\mathrm{SO}_{2}$ shows a maximum at $\sim 0.5 \mathrm{~km}$ altitude, owing to the predominantly elevated emissions from large industrial sources. Together with the diurnal variation of the PBL, a distinct temporal pattern of $\mathrm{SO}_{2}$ is apparent near the surface, as described above (Sect. 3.1) and in previous studies (Lin et al., 2008, 2009). Due to weaker titration by NO and the active photochemistry, relatively high $\mathrm{O}_{3}$ concentrations may occur near the top of the mixing layer $(\sim 100 \mathrm{~m}$ above the surface). However, such $\mathrm{O}_{3}$ peaks could not be observed during IPAC-NC since our aircraft was not allowed to fly below $400 \mathrm{~m}$ above the ground. The $\mathrm{O}_{3}$ mixing ratios were generally higher near the surface compared to higher altitudes within the PBL. These vertical profiles are similar to the tropospheric ozone climatology over Beijing, as observed in the MOZAIC program (Ding et al., 2008). A remarkable $\mathrm{O}_{3}$ increase at an altitude of $0.5-1.5 \mathrm{~km}$ was observed over Beijing during the summer afternoon (Ding et al., 2008). An elevated pollution layer was also observed over Beijing at 2500-3500 m 

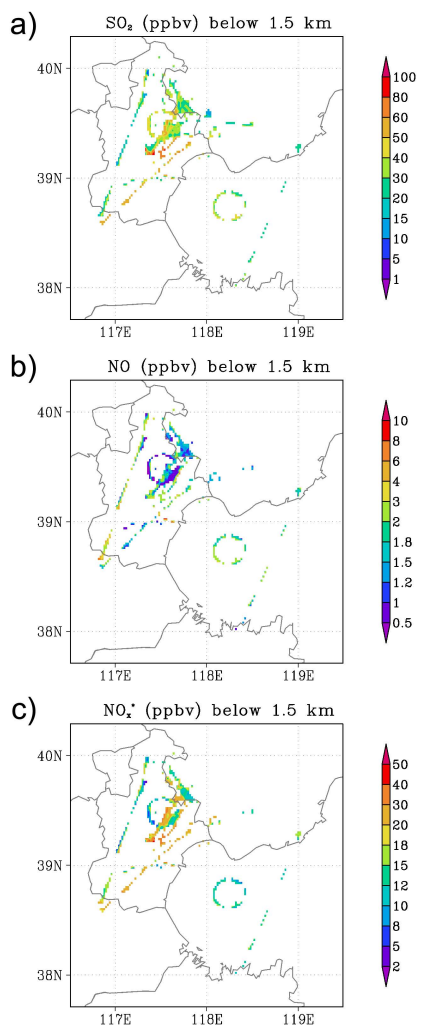
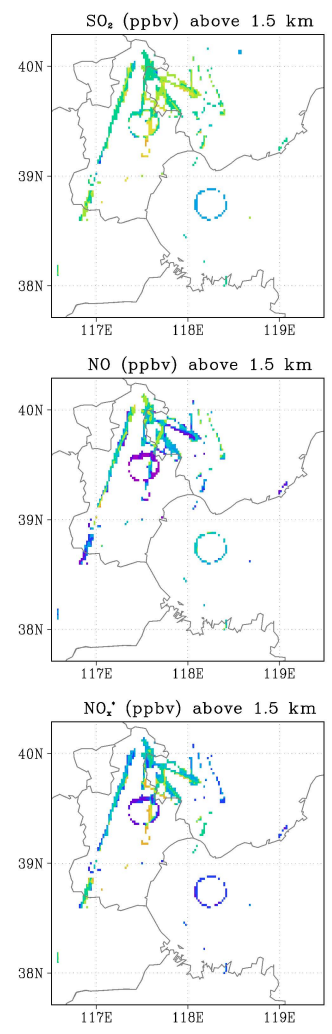

d)

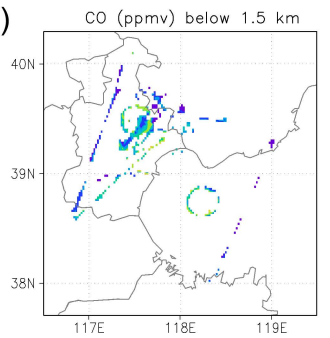

e)

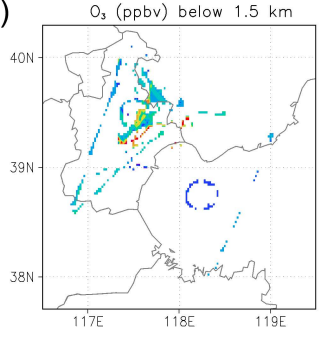

f)

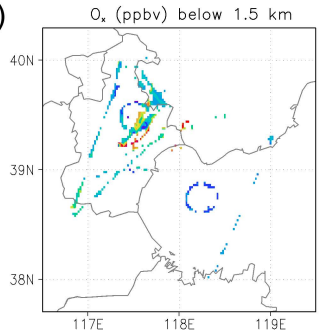

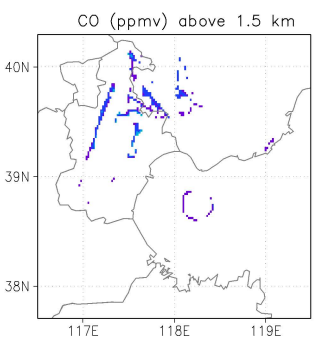

$\mathrm{O}_{3}$ (ppbv) above $1.5 \mathrm{~km}$

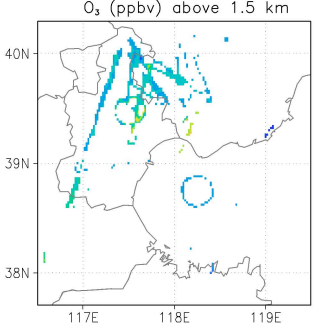

$\mathrm{O}_{x}$ (ppbv) above $1.5 \mathrm{~km}$

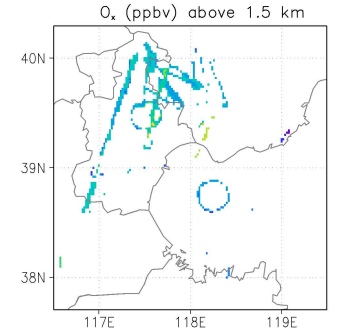

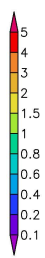

Fig. 9. Flight track of all data collected from the aircraft below (left) and above (right) $1.5 \mathrm{~km}$ colored by (a) $\mathrm{SO}_{2}$, (b) $\mathrm{NO}$, (c) $\mathrm{NO}_{\mathrm{x}}^{*}$, (d) $\mathrm{CO}$, (e) $\mathrm{O}_{3}$, and (f) $\mathrm{O}_{\mathrm{x}}$ mixing ratios during IPAC-NC.

altitude during summer, attributed to a mountain chimney effect (Chen et al., 2009). The increases in $\mathrm{O}_{3}$ and other pollutants at these altitudes were generally not significant over the Tianjin, Tangshan and Bohai area during the spring IPAC$\mathrm{NC}$ campaign although some episodic enhancements were observed. Note that our aircraft may have missed such profiles since the chemistry instruments were switched off during take-off and landing at Tianjin airport. A summary of daytime meteorological parameters and trace gas concentrations, including NMHCs, observed during IPAC-NC is given in Table 3. The data obtained at the Xin'an site are assumed to be representative for the region at the surface.

\subsection{Estimated radical concentrations}

We calculated radical concentrations and chemical reaction rates with the chemical box model (see Sect. 2.2), constrained by the observed mean trace gas concentrations, shown in Fig. 10 as well as in Table 3. As described in Sect. 2.2, heterogeneous reactions of trace gases and radicals on aerosol surfaces were added to the model, and the mean vertical distributions of aerosol number concentrations and particle surface areas measured during IPAC-NC were used to calculate photolysis (J-values) and heterogeneous reaction rates. As shown in Fig. 11, during the campaign the number concentrations of aerosol particles were dominated by the nucleation mode and lower Aiken mode $\left(5 \mathrm{~nm}<D_{\mathrm{p}}<100 \mathrm{~nm}\right)$ at higher altitudes $(>\sim 1.5 \mathrm{~km})$ and by the Aiken mode and lower accumulation mode $\left(20 \mathrm{~nm}<D_{\mathrm{p}}<200 \mathrm{~nm}\right)$ at lower altitudes $(<\sim 1.5 \mathrm{~km})$. Correspondingly, the aerosol surface areas were dominated by the accumulation mode with a peak centered at $D_{\mathrm{p}} \approx 200 \mathrm{~nm}$, and to a lesser extent by the coarse mode with a peak centered at $D_{\mathrm{p}} \approx 1.5 \mu \mathrm{m}$, the latter being related to dust aerosols. The total number density of aerosols was about $1.4 \times 10^{4}$ particles $\mathrm{cm}^{-3}$ near the surface, and $1.7 \times 10^{4}$ and $3.0 \times 10^{4}$ particles $\mathrm{cm}^{-3}$ at 1 and $2 \mathrm{~km}$ altitudes, respectively. The surface area concentration of aerosols was about $3.8 \times 10^{2} \mu \mathrm{m}^{2} \mathrm{~cm}^{-3}$ near the surface, and $2.4 \times 10^{2}$ and $1.3 \times 10^{2} \mu \mathrm{m}^{2} \mathrm{~cm}^{-3}$ at 1 and $2 \mathrm{~km}$ altitude, respectively. These measured vertical distributions of aerosol physical parameters were extrapolated to the surface to be included in our model. We considered four scenarios for the model simulations. "BASE" refers to the standard simulation, and "NO_S" and "NO_H" are sensitivity simulations without considering $\mathrm{SO}_{2}$-associated reactions and heterogeneous reactions of $\mathrm{OH}$ and $\mathrm{HO}_{2}$ on aerosol surfaces, respectively. The initial $\mathrm{CH}_{2} \mathrm{O}$ mixing ratio was assumed to be $5 \mathrm{ppbv}$ at the surface, increasing to $1.5 \mathrm{ppbv}$ at $2.0 \mathrm{~km}$ altitude in the cases above. To investigate the role of $\mathrm{CH}_{2} \mathrm{O}$, we performed additional simulations (the " $1.3 * \mathrm{CH}_{2} \mathrm{O}$ " case) 

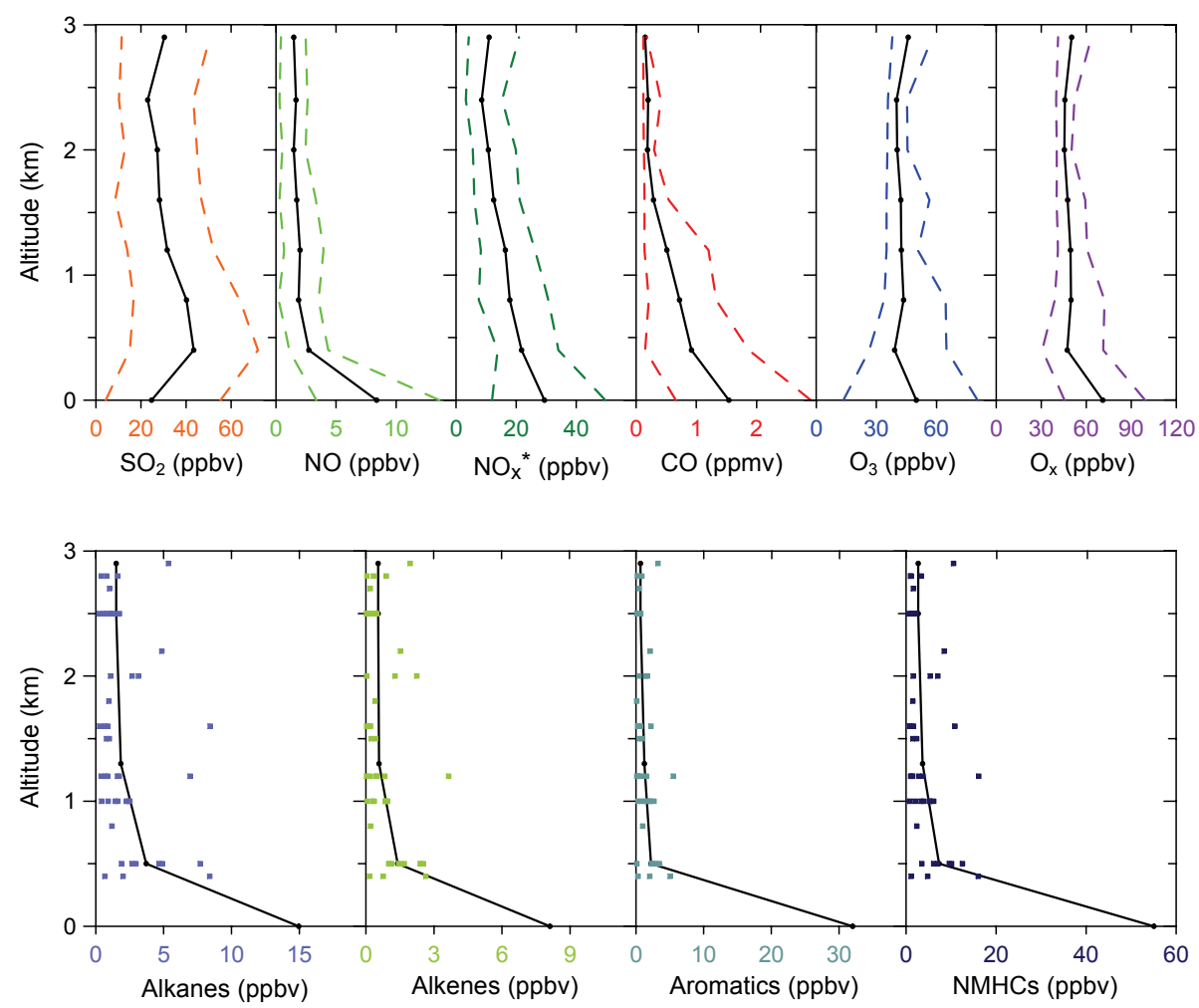

Fig. 10. Vertical profiles of gaseous pollutants measured by aircraft combined with daytime surface measurements at the Xin'an station. Black solid lines are mean values, colored dashed lines are 10th and 90th percentiles of the data for inorganic gases, and colored dots are values for each VOC sample. $\mathrm{O}_{\mathrm{x}}$ is $\mathrm{O}_{3}$ plus $\mathrm{NO}_{2}$, the latter derived by scaling measured $\mathrm{NO}$ with the $\mathrm{NO}_{2} / \mathrm{NO}$ ratios simulated with our RCTM.

with a 3 ppbv increase in $\mathrm{CH}_{2} \mathrm{O}$ mixing ratio at the surface (to 8 ppbv) and a $30 \%$ increase aloft (reaching $2.0 \mathrm{ppbv}$ at $2.0 \mathrm{~km}$ ) relative to the "BASE" case. Eight altitude levels, $0.0 \mathrm{~km}, 0.4 \mathrm{~km}, 0.8 \mathrm{~km}, 1.2 \mathrm{~km}, 1.6 \mathrm{~km}, 2.0 \mathrm{~km}, 2.4 \mathrm{~km}$ and $2.8 \mathrm{~km}$, were selected in our calculations.

Figure $12 \mathrm{a}$ and $\mathrm{b}$ present the calculated vertical profiles of $\mathrm{OH}$ and $\mathrm{HO}_{2}$ concentrations, respectively. Interestingly, we find a peak in the vertical profiles of both $\mathrm{OH}$ and $\mathrm{HO}_{2}$ at about $1 \mathrm{~km}$ altitude. The calculated daytime mean $\mathrm{OH}$ concentration is $5.4-6.0 \times 10^{6}$ molecules $\mathrm{cm}^{-3}(0.22-$ $0.24 \mathrm{pptv})$ at the surface, increasing to peak values of 6.9 $8.5 \times 10^{6}$ molecules $\mathrm{cm}^{-3}(0.29-0.36 \mathrm{pptv})$ at an altitude of $0.8 \mathrm{~km}$. The profile of $\mathrm{HO}_{2}$ is similar to that of $\mathrm{OH}$, with a maximum of $1.8-2.3 \times 10^{8}$ molecules $\mathrm{cm}^{-3}$ (7.7-9.8 pptv) at $0.8 \mathrm{~km}$. The estimated surface level of $\mathrm{OH}$ in the polluted rural area of Huabei is comparable to that in the Mexico City Metropolitan Area (MCMA) and higher than that in New York City (NYC). According to the measurements by Ren et al. (2003) and Shirley et al. (2006), the diurnal peak of median $\mathrm{OH}$ was $0.28 \mathrm{pptv}$ in NYC $\left(40.7^{\circ} \mathrm{N}\right.$ latitude) in July 2001 and 0.35 pptv $\left(\sim 7 \times 10^{6}\right.$ molecules $\left.\mathrm{cm}^{-3}\right)$ in MCMA $\left(19.4^{\circ} \mathrm{N}\right.$ latitude) in April 2003. A high average $\mathrm{OH}$ concentration of $15 \times 10^{6}$ molecules $\mathrm{cm}^{-3}$ around noon was observed in the polluted rural area of the Pearl
River Delta (PRD) in China $\left(23.5^{\circ} \mathrm{N}\right.$ latitude) during July 2006, which could not be reproduced by the model calculations of Hofzumahaus et al. (2009). Our OH estimate for Huabei is much lower than observed in the PRD, but it is comparable to the $\mathrm{OH}$ simulated for PRD (the latter with a diurnal peak of $\sim 7 \times 10^{6}$ molecules $\mathrm{cm}^{-3}$ ). Unaccounted $\mathrm{OH}$ recycling remains a challenge, and it is conceivable that our model also underestimates $\mathrm{OH}$, in particular because the chemistry of aromatics has similarities with that of isoprene, which has been identified as a molecule that efficiently recycles OH (Lelieveld et al., 2008; Hofzumahaus et al., 2009; Taraborrelli et al., 2012). However, the reaction pathways as measured in the laboratory and those predicted by ab initio chemical dynamics calculations are at odds (Crounse et al., 2011; Peeters and Muller, 2010), and additional work will be needed to elucidate these mechanisms (Pilling, 2012).

Measurements of $\mathrm{OH}$ vertical profiles are sparse compared to ground-based observations. As reviewed by Singh et al. (2009), INTEX-B provided detailed vertical distributions of $\mathrm{OH}$ measured over the Gulf of Mexico and the subtropical Pacific in spring 2006, during the same season as the IPAC-NC campaign. OH levels in the lower atmosphere estimated for Huabei are similar to those over the Gulf of Mexico and 2-3 times higher than those over the 
Table 3. Summary of daytime meteorological parameters and trace gas mixing ratios (mean value plus/minus standard deviation, and median value of the data) observed during IPAC-NC.

\begin{tabular}{|c|c|c|c|c|c|c|}
\hline \multirow[t]{2}{*}{ Parameter } & \multicolumn{2}{|c|}{ Surface } & \multicolumn{2}{|c|}{$0.5-1.5 \mathrm{~km}$ altitude } & \multicolumn{2}{|c|}{$1.5-3 \mathrm{~km}$ altitude } \\
\hline & Mean \pm Std & Median & Mean \pm Std & Median & Mean \pm Std & Median \\
\hline Temperature $\left({ }^{\circ} \mathrm{C}\right)$ & $17.2 \pm 6.0$ & 17.6 & $12.6 \pm 5.2$ & 12.1 & $5.0 \pm 6.0$ & 4.3 \\
\hline Relative humidity (\%) & $41.6 \pm 23.4$ & 36.0 & $56.4 \pm 24.5$ & 58.5 & $49.8 \pm 22.2$ & 43.0 \\
\hline $\mathrm{SO}_{2}$ & $24.7 \pm 20.9$ & 18.6 & $37.0 \pm 18.7$ & 32.6 & $26.2 \pm 12.9$ & 25.5 \\
\hline $\mathrm{NO}$ & $8.4 \pm 15.6$ & 4.5 & $2.3 \pm 2.0$ & 1.9 & $1.6 \pm 1.0$ & 1.5 \\
\hline $\mathrm{NO}_{\mathrm{x}}^{*}$ & $29.4 \pm 23.1$ & 23.4 & $18.7 \pm 9.4$ & 16.8 & $10.6 \pm 6.0$ & 8.9 \\
\hline $\mathrm{CO}$ (ppmv) & $1.5 \pm 1.0$ & 1.2 & $0.67 \pm 0.64$ & 0.47 & $0.23 \pm 0.15$ & 0.17 \\
\hline $\mathrm{O}_{3}$ & $49.9 \pm 26.3$ & 51.6 & $41.7 \pm 10.8$ & 39.5 & $41.2 \pm 6.2$ & 39.7 \\
\hline $\mathrm{O}_{\mathrm{X}}$ & $71.0 \pm 22.1$ & 67.9 & $49.0 \pm 11.7$ & 46.4 & $46.4 \pm 6.4$ & 44.8 \\
\hline Ethane & $3.12 \pm 1.54$ & 2.84 & - & - & - & - \\
\hline Ethylene & $2.88 \pm 2.00$ & 2.00 & - & - & - & - \\
\hline Propylene & $1.61 \pm 2.59$ & 1.05 & - & - & - & - \\
\hline Propane & $2.23 \pm 1.95$ & 1.68 & $0.25 \pm 0.18$ & 0.19 & $0.15 \pm 0.16$ & 0.09 \\
\hline n-Butane & - & - & $0.49 \pm 0.48$ & 1.05 & $0.16 \pm 0.14$ & 0.11 \\
\hline Isobutane & $1.12 \pm 1.22$ & 0.69 & $0.30 \pm 0.26$ & 0.21 & $0.09 \pm 0.07$ & 0.05 \\
\hline 1-Butene/Isobutene & $1.06 \pm 3.02$ & 0.00 & $0.35 \pm 0.38$ & 0.28 & $0.20 \pm 0.26$ & 0.07 \\
\hline 2-Butene & $0.83 \pm 2.91$ & 0.00 & $0.02 \pm 0.04$ & 0.00 & $0.01 \pm 0.03$ & 0.00 \\
\hline Pentane & $1.85 \pm 3.10$ & 0.77 & $0.23 \pm 0.25$ & 0.12 & $0.07 \pm 0.07$ & 0.04 \\
\hline 2-Methyl-butane & - & - & $0.45 \pm 0.51$ & 0.28 & $0.19 \pm 0.25$ & 0.09 \\
\hline Pentene & $0.64 \pm 1.94$ & 0.00 & $0.06 \pm 0.23$ & 0.00 & $0.01 \pm 0.04$ & 0.00 \\
\hline n-Hexane & $0.84 \pm 0.14$ & 0.00 & $0.12 \pm 0.13$ & 0.05 & $0.04 \pm 0.05$ & 0.03 \\
\hline 2,2-Dimethylbutane & $0.32 \pm 0.55$ & 0.00 & $0.03 \pm 0.06$ & 0.01 & $0.02 \pm 0.03$ & 0.00 \\
\hline 2-Methylpentane & $0.33 \pm 0.62$ & 0.00 & $0.10 \pm 0.15$ & 0.01 & $0.04 \pm 0.09$ & 0.00 \\
\hline 3-Methylpentane & $0.31 \pm 0.77$ & 0.00 & $0.07 \pm 0.09$ & 0.03 & $0.04 \pm 0.07$ & 0.01 \\
\hline 4-Methyl-1-pentene & $0.07 \pm 0.15$ & 0.00 & $0.08 \pm 0.07$ & 0.06 & $0.02 \pm 0.02$ & 0.00 \\
\hline Benzene & $16.63 \pm 25.41$ & 5.51 & $0.88 \pm 0.59$ & 0.79 & $0.28 \pm 0.24$ & 0.19 \\
\hline n-Heptane & $1.13 \pm 1.58$ & 0.00 & $0.06 \pm 0.06$ & 0.04 & $0.02 \pm 0.03$ & 0.01 \\
\hline 2,3-Dimethylpentane & $0.45 \pm 1.12$ & 0.00 & $0.16 \pm 0.31$ & 0.03 & $0.09 \pm 0.16$ & 0.01 \\
\hline 2,4-Dimethylpentane & $0.11 \pm 0.17$ & 0.00 & $0.16 \pm 0.32$ & 0.08 & $0.16 \pm 0.19$ & 0.07 \\
\hline 2-methylhexane & $0.37 \pm 0.84$ & 0.00 & $0.04 \pm 0.04$ & 0.00 & $0.02 \pm 0.04$ & 0.00 \\
\hline Toluene & $7.31 \pm 18.14$ & 0.00 & $0.54 \pm 0.59$ & 0.27 & $0.19 \pm 0.20$ & 0.08 \\
\hline n-Octane & $0.75 \pm 1.05$ & 0.00 & $0.04 \pm 0.07$ & 0.00 & $0.00 \pm 0.01$ & 0.00 \\
\hline 2,2,4-Trimethylpentane & $0.11 \pm 0.17$ & 0.00 & $0.05 \pm 0.15$ & 0.00 & $0.10 \pm 0.29$ & 0.00 \\
\hline 2,3,4-Trimethylpentane & $0.08 \pm 0.13$ & 0.00 & $0.06 \pm 0.20$ & 0.00 & $0.07 \pm 0.18$ & 0.00 \\
\hline m,p-Xylene & $2.23 \pm 3.44$ & 0.03 & $0.14 \pm 0.20$ & 0.00 & $0.10 \pm 0.15$ & 0.02 \\
\hline Ethylbenzene & $1.87 \pm 2.47$ & 0.59 & $0.08 \pm 0.08$ & 0.04 & $0.03 \pm 0.04$ & 0.01 \\
\hline n-Nonane & $0.13 \pm 0.45$ & 0.00 & $0.05 \pm 0.11$ & 0.00 & $0.09 \pm 0.38$ & 0.00 \\
\hline 1,2,4-Trimethylbenzene & $1.46 \pm 1.96$ & 0.11 & $0.05 \pm 0.05$ & 0.04 & $0.05 \pm 0.08$ & 0.02 \\
\hline Total alkanes & $15.0 \pm 7.7$ & 14.2 & $2.7 \pm 2.3$ & 1.7 & $1.8 \pm 1.9$ & 1.0 \\
\hline Total alkenes & $8.1 \pm 7.6$ & 6.0 & $1.0 \pm 0.9$ & 0.8 & $0.5 \pm 0.6$ & 0.2 \\
\hline Total aromatics & $32.0 \pm 40.5$ & 15.7 & $1.8 \pm 1.4$ & 1.5 & $0.8 \pm 08$ & 0.4 \\
\hline Total NMHCs & $55.1 \pm 45.7$ & 34.5 & $5.5 \pm 4.4$ & 3.7 & $3.1 \pm 3.1$ & 1.6 \\
\hline
\end{tabular}

Units are ppbv except for specified parameters.

subtropical Pacific. The mean vertical profile of $\mathrm{OH}$ derived for Huabei is also similar to that over the Gulf of Mexico, the latter having a peak around $\sim 0.3 \mathrm{pptv}$ at an altitude of 3-4 km a.s.l., as shown by Singh et al. (2009) (note that MCMA is at an altitude of $2240 \mathrm{~m}$ a.s.l.). A similar OH profile was observed over the Suriname rainforest during the GABRIEL campaign, with a peak concentration at $2-3 \mathrm{~km}$ altitude (Lelieveld et al., 2008; Kubistin et al., 2010). The transport and evolution of Asian pollution over the Pacific have been thought to have a substantial impact on surface air quality along the west coast of North America (Zhang et al., 2008a; Singh et al., 2009). Higher OH concentrations in the lower atmosphere over Huabei, one of the most severely polluted regions in Asia, compared to those over the Pacific indicate that primary pollutants are oxidized more efficiently in Huabei than over the Pacific towards North America. Such 

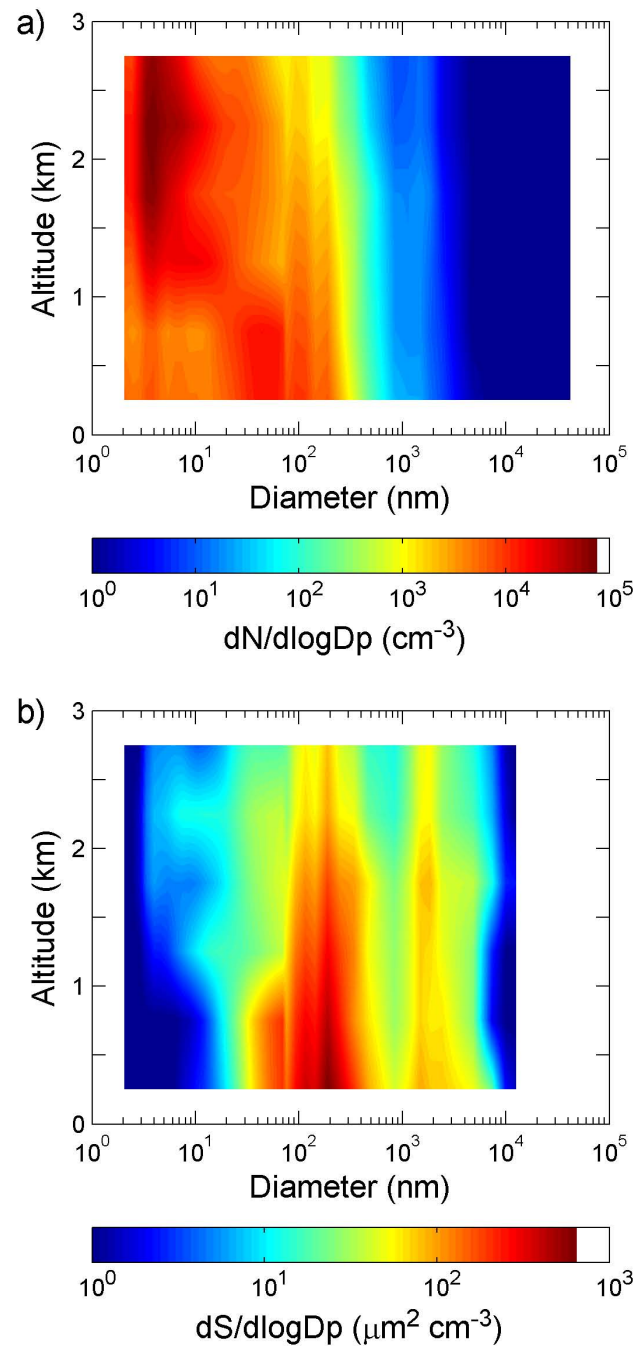

Fig. 11. Size distributions of (a) aerosol number and (b) surface area as a function of altitude, measured by aircraft.

an enhancement in the oxidation capacity of the lower atmosphere over Huabei can also promote the formation of ozone and secondary aerosols in the region. Apparently, Huabei is not only a highly polluted region but also acts as an oxidation pool over China.

\section{5 $\mathrm{HO}_{\mathrm{x}}$ radical budget and relevant chemical reactions}

An overview of the most relevant reactions for the $\mathrm{HO}_{\mathrm{x}}$ budget over the polluted region of Huabei is given in Tables 4 and 5. The photolysis of ozone followed by reaction with water vapor, together called the effective photolysis of ozone (Ma and van Weele, 2000; Ma et al., 2002b), is the main source of tropospheric $\mathrm{OH}$ on a global scale (Lelieveld et al., 2002b; Rohrer and Berresheim, 2006). In contrast, in the lower atmosphere over Huabei, this primary $\mathrm{OH}$ production merely contributes $6-7 \%$ to the total production of $\mathrm{OH}$. The $\mathrm{OH}$ radical recycling by reaction $\mathrm{NO}+\mathrm{HO}_{2}$ makes a domi-
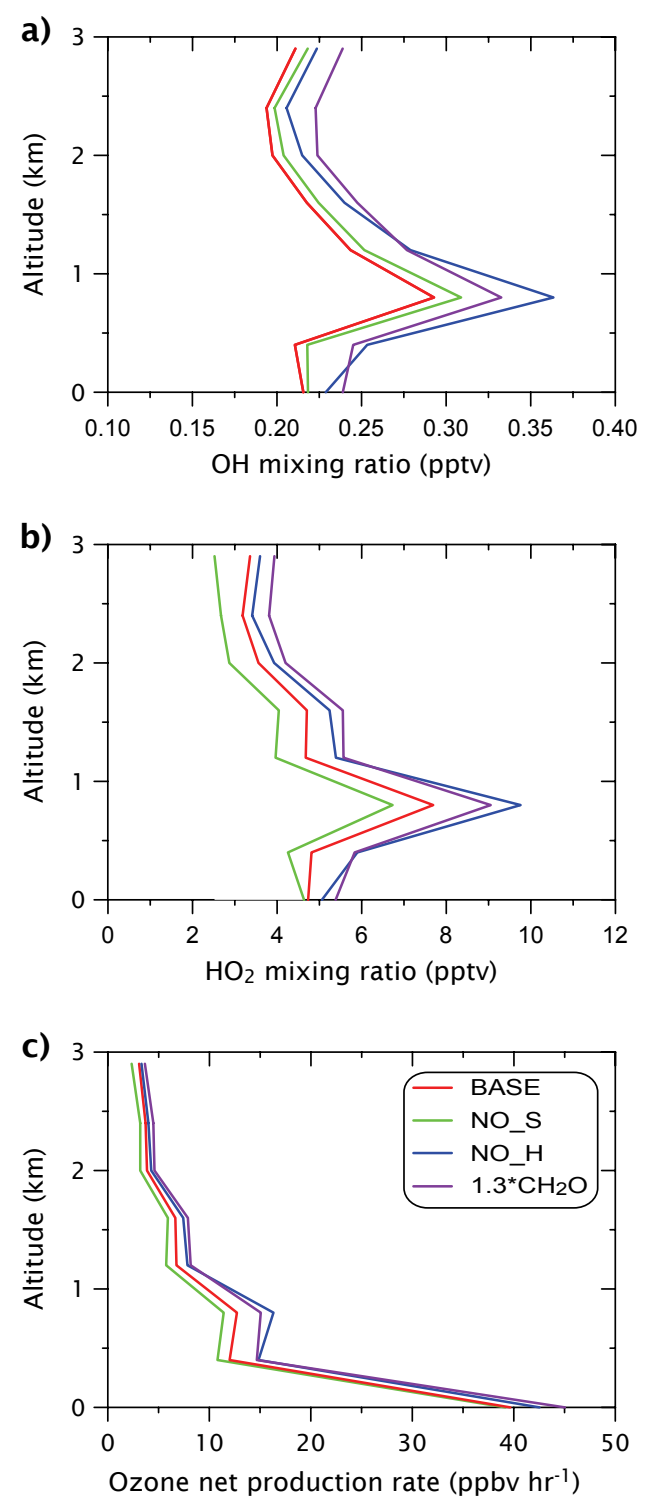

Fig. 12. Vertical profiles of (a) $\mathrm{OH}$, (b) $\mathrm{HO}_{2}$, and (c) $\mathrm{O}_{3}$ production rates, calculated using the NCAR Master Mechanism constrained by measured daytime mean trace gas and aerosol concentrations. BASE refers to the standard simulation, and NO_S and NO_H to sensitivity simulations without considering $\mathrm{SO}_{2}$ related reactions and heterogeneous reactions of $\mathrm{OH}$ and $\mathrm{HO}_{2}$ on aerosol surfaces, respectively. " $1.3 * \mathrm{CH}_{2} \mathrm{O}$ " refers to the simulations with a 3 ppbv increase of the $\mathrm{CH}_{2} \mathrm{O}$ mixing ratio at the surface and a $30 \%$ increase aloft relative to the BASE case.

nant contribution $(90 \pm 3 \%)$ to the total production. At the surface, the contribution of $\mathrm{HNO}_{2}$ photolysis $(2.4 \%)$ is comparable to that of ozone photolysis $(1.6 \%)$, in accord with previous results for strongly polluted areas (Volkamer et al., 2010 and references therein). The contributions of other reactions, including the photolysis of $\mathrm{H}_{2} \mathrm{O}_{2}$, are much smaller $(\sim 1 \%)$. The primary radical production from the effective 
Table 4. OH budget at different altitudes based on a model analysis of measurement data with and without considering heterogeneous reactions (HR) of $\mathrm{OH}$ and $\mathrm{HO}_{2}$ on aerosol surfaces.

\begin{tabular}{|c|c|c|c|c|c|c|c|c|}
\hline \multirow[t]{2}{*}{ Item } & \multicolumn{2}{|c|}{ Surface } & \multicolumn{2}{|c|}{$0.8 \mathrm{~km}$} & \multicolumn{2}{|c|}{$1.6 \mathrm{~km}$} & \multicolumn{2}{|c|}{$2.4 \mathrm{~km}$} \\
\hline & HR & NO_HR & HR & NO_HR & HR & NO_HR & HR & NO_HR \\
\hline Production $\left(\right.$ molec $\left.\mathrm{cm}^{-3} \mathrm{~s}^{-1}\right)$ & $2.4 \times 10^{8}$ & $2.5 \times 10^{8}$ & $8.3 \times 10^{7}$ & $1.0 \times 10^{8}$ & $3.9 \times 10^{7}$ & $4.3 \times 10^{7}$ & $2.2 \times 10^{7}$ & $2.3 \times 10^{7}$ \\
\hline $\mathrm{NO}+\mathrm{HO}_{2}$ & $93 \%$ & $93 \%$ & $91 \%$ & $92 \%$ & $88 \%$ & $89 \%$ & $87 \%$ & $87 \%$ \\
\hline $\mathrm{HNO}_{2}+h v$ & $2 \%$ & $2 \%$ & $2 \%$ & $2 \%$ & $2 \%$ & $2 \%$ & $3 \%$ & $3 \%$ \\
\hline $\mathrm{H}_{2} \mathrm{O}+\mathrm{O}\left({ }^{1} \mathrm{D}\right)$ & $2 \%$ & $2 \%$ & $6 \%$ & $5 \%$ & $7 \%$ & $6 \%$ & $7 \%$ & $7 \%$ \\
\hline$\left[\mathrm{CH}_{3} \mathrm{CHOO}\right]^{*}$ & $1 \%$ & $1 \%$ & $<1 \%$ & $<1 \%$ & $<1 \%$ & $<1 \%$ & $<1 \%$ & $<1 \%$ \\
\hline $\mathrm{H}_{2} \mathrm{O}+\mathrm{CH}_{3} \mathrm{CH} .(\mathrm{OO})$. & $1 \%$ & $1 \%$ & $<1 \%$ & $<1 \%$ & $<1 \%$ & $<1 \%$ & $<1 \%$ & $<1 \%$ \\
\hline $\mathrm{H}_{2} \mathrm{O}_{2}+\mathrm{h} v$ & $<1 \%$ & $<1 \%$ & $<1 \%$ & $<1 \%$ & $1 \%$ & $1 \%$ & $1 \%$ & $1 \%$ \\
\hline remaining & $<1 \%$ & $<1 \%$ & $<1 \%$ & $<1 \%$ & $<2 \%$ & $<2 \%$ & $<2 \%$ & $<2 \%$ \\
\hline Loss $\left(\right.$ molec $\left.\mathrm{cm}^{-3} \mathrm{~s}^{-1}\right)$ & $2.4 \times 10^{8}$ & $2.5 \times 10^{8}$ & $8.3 \times 10^{7}$ & $1.0 \times 10^{8}$ & $3.9 \times 10^{7}$ & $4.3 \times 10^{7}$ & $2.2 \times 10^{7}$ & $2.3 \times 10^{7}$ \\
\hline $\mathrm{CO}+\mathrm{OH}$ & $21 \%$ & $21 \%$ & $33 \%$ & $33 \%$ & $17 \%$ & $17 \%$ & $15 \%$ & $15 \%$ \\
\hline $\mathrm{NO}_{2}+\mathrm{OH}$ & $18 \%$ & $18 \%$ & $14 \%$ & $14 \%$ & $17 \%$ & $17 \%$ & $21 \%$ & $21 \%$ \\
\hline $\mathrm{C}_{6} \mathrm{H}_{4} \mathrm{CH}_{3}, \mathrm{CH}_{3}+\mathrm{OH}$ & $8 \%$ & $8 \%$ & $1 \%$ & $1 \%$ & $2 \%$ & $2 \%$ & $2 \%$ & $2 \%$ \\
\hline $\mathrm{CH}_{3} \mathrm{CH}=\mathrm{CHCH}_{3}+\mathrm{OH}$ & $8 \%$ & $8 \%$ & $1 \%$ & $1 \%$ & $<1 \%$ & $<1 \%$ & $<1 \%$ & $<1 \%$ \\
\hline $\mathrm{CH}_{3} \mathrm{C}\left(\mathrm{CH}_{3}\right)=\mathrm{CH}_{2}+\mathrm{OH}$ & $6 \%$ & $6 \%$ & $6 \%$ & $6 \%$ & $5 \%$ & $5 \%$ & $5 \%$ & $5 \%$ \\
\hline $\mathrm{CH}_{3} \mathrm{CHO}+\mathrm{OH}$ & $5 \%$ & $5 \%$ & $4 \%$ & $4 \%$ & $3 \%$ & $3 \%$ & $2 \%$ & $2 \%$ \\
\hline $\mathrm{C}_{6} \mathrm{H}_{5} \mathrm{CH}_{3}+\mathrm{OH}$ & $3 \%$ & $3 \%$ & $1 \%$ & $1 \%$ & $<1 \%$ & $<1 \%$ & $<1 \%$ & $<1 \%$ \\
\hline $\mathrm{SO}_{2}+\mathrm{OH}$ & $3 \%$ & $3 \%$ & $16 \%$ & $16 \%$ & $15 \%$ & $15 \%$ & $16 \%$ & $16 \%$ \\
\hline $\mathrm{CH}_{2} \mathrm{O}+\mathrm{OH}$ & $3 \%$ & $3 \%$ & $6 \%$ & $6 \%$ & $6 \%$ & $6 \%$ & $5 \%$ & $5 \%$ \\
\hline $\mathrm{C}_{3} \mathrm{H}_{6}+\mathrm{OH}$ & $3 \%$ & $3 \%$ & $2 \%$ & $2 \%$ & $2 \%$ & $2 \%$ & $2 \%$ & $2 \%$ \\
\hline $\mathrm{CHOCH}=\mathrm{C}\left(\mathrm{CH}_{3}\right) \mathrm{CHO}+\mathrm{OH}$ & $3 \%$ & $3 \%$ & $<1 \%$ & $<1 \%$ & $<1 \%$ & $<1 \%$ & $<1 \%$ & $<1 \%$ \\
\hline $\mathrm{NO}+\mathrm{OH}$ & $3 \%$ & $2 \%$ & $2 \%$ & $2 \%$ & $2 \%$ & $2 \%$ & $3 \%$ & $3 \%$ \\
\hline $\mathrm{CH}_{4}+\mathrm{OH}$ & $<2 \%$ & $<2 \%$ & $2 \%$ & $2 \%$ & $2 \%$ & $2 \%$ & $3 \%$ & $3 \%$ \\
\hline $\mathrm{C}_{9} \mathrm{H}_{13} \mathrm{CH}_{3}+\mathrm{OH}$ & $<2 \%$ & $<2 \%$ & $<2 \%$ & $<2 \%$ & $7 \%$ & $7 \%$ & $6 \%$ & $6 \%$ \\
\hline $\mathrm{dtA} 1+\mathrm{OH}$ & $<2 \%$ & $<2 \%$ & $<2 \%$ & $<2 \%$ & $6 \%$ & $6 \%$ & $5 \%$ & $5 \%$ \\
\hline remaining & $<16 \%$ & $<17 \%$ & $<12 \%$ & $<12 \%$ & $<16 \%$ & $<16 \%$ & $<15 \%$ & $<15 \%$ \\
\hline Concentration $\left(\right.$ molec $\left.\mathrm{cm}^{-3}\right)$ & $5.4 \times 10^{6}$ & $5.7 \times 10^{6}$ & $6.9 \times 10^{6}$ & $8.5 \times 10^{6}$ & $4.7 \times 10^{6}$ & $5.2 \times 10^{6}$ & $3.8 \times 10^{6}$ & $4.1 \times 10^{6}$ \\
\hline
\end{tabular}

$\left[\mathrm{CH}_{3} \mathrm{CHOO}\right]^{*}$ : Excited Criegee biradical, formed predominantly by the reactions $\mathrm{CH}_{3} \mathrm{CH}=\mathrm{CHCH}_{3}+\mathrm{O}_{3}$ and $\mathrm{CH}_{3} \mathrm{CH}=\mathrm{CH}_{2}+\mathrm{O}_{3}$.

$\mathrm{CH}_{3} \mathrm{CH} \cdot(\mathrm{OO} \cdot)$ : Collisionally stabilized Criegee biradical from $\left[\mathrm{CH}_{3} \mathrm{CHOO}\right]^{*}$.

dtA1: $\mathrm{CH}_{3} \mathrm{CO}^{\prime} \mathrm{CH}^{\prime} \mathrm{CH}_{2}^{\prime} \mathrm{CH}\left(\mathrm{CH}_{2} \mathrm{CHO}\right)^{\prime} \mathrm{CCH}_{3} \mathrm{CH}_{3}$.

photolysis of $\mathrm{O}_{3}$ and other species depends on the intensity of solar radiation as well as the species' abundance, providing a net source of $\mathrm{OH}$. The recycling of $\mathrm{OH}$ from $\mathrm{HO}_{2}$ can compensate for $\mathrm{OH}$ losses by the reactions with $\mathrm{CO}$ and hydrocarbons, and the latter can even enhance $\mathrm{OH}$, depending on the reaction pathways (Lelieveld et al., 2002b). For example, the loss of $\mathrm{OH}$ after its initial reaction to reactive carbon compounds can be followed by its recycling from $\mathrm{HO}_{2}$ through the reaction with $\mathrm{NO}$ in polluted areas, and with $\mathrm{O}_{3}$ in remote areas. Many hydrocarbon oxidation pathways lead to $\mathrm{OH}$ through the formation and breakdown of oxygenated intermediates such as aldehydes. There are indications that the $\mathrm{OH}$ yield from these intermediates can even overcompensate the $\mathrm{OH}$ loss from the initial hydrocarbon attack (Taraborrelli et al., 2012). Although $\mathrm{NO}$ efficiently recycles $\mathrm{OH}$ from $\mathrm{HO}_{2}$, very high $\mathrm{NO}_{\mathrm{x}}$ suppresses $\mathrm{OH}$ levels by the reaction of $\mathrm{NO}_{2}$ with $\mathrm{OH}$ into $\mathrm{HNO}_{3}$, which is efficiently removed by deposition processes.

Our model analysis suggests that, with respect to individual species, the loss of $\mathrm{OH}$ over the polluted region of Huabei is dominated by the reaction with CO (15-33\%), followed by the reaction with $\mathrm{NO}_{2}$ (14-21\%). Interestingly, we find that the reaction with $\mathrm{SO}_{2}$ also makes a substantial contribution $(15-16 \%)$ to the $\mathrm{OH}$ loss in the lower atmosphere, i.e. well above the ground, owing to high levels of $\mathrm{SO}_{2}$ over the region.

$$
\begin{gathered}
\mathrm{SO}_{2}+\mathrm{OH}+\mathrm{M} \longrightarrow \mathrm{HOSO}_{2}+\mathrm{M}, \\
\mathrm{HOSO}_{2}+\mathrm{O}_{2} \longrightarrow \mathrm{HO}_{2}+\mathrm{SO}_{3}, \\
\mathrm{SO}_{3}+\mathrm{H}_{2} \mathrm{O}+\mathrm{M} \longrightarrow \mathrm{H}_{2} \mathrm{SO}_{4}+\mathrm{M}, \\
\mathrm{SO}_{2}+\mathrm{OH}+\mathrm{H}_{2} \mathrm{O} \stackrel{\mathrm{O}_{2}}{\longrightarrow} \mathrm{HO}_{2}+\mathrm{H}_{2} \mathrm{SO}_{4} .
\end{gathered}
$$

Due to its short lifetime $\left(\tau_{\mathrm{OH}}<0.1 \mathrm{~s}\right)$, $\mathrm{OH}$ rapidly reaches steady state between production and loss.

$\frac{\mathrm{d}[\mathrm{OH}]}{\mathrm{d} t}=P(\mathrm{OH})-L_{\mathrm{OH}} \cdot[\mathrm{OH}] \approx 0$.

The pseudo first-order rate coefficient of $\mathrm{OH}\left(L_{\mathrm{OH}}\right)$, i.e. the inverse of the atmospheric $\mathrm{OH}$ lifetime $\left(\tau_{\mathrm{OH}}^{-1}\right)$, is an important parameter that has been used to measure the total $\mathrm{OH}$ 
reactivity in the atmosphere (e.g. Mao et al., 2009; Sheehy et al., 2010; Sinha et al., 2010; Lou et al., 2010).

$L_{\mathrm{OH}}=\sum_{i} k_{\mathrm{OH}+\mathrm{X}_{i}} \cdot\left[\mathrm{X}_{i}\right]=\tau_{\mathrm{OH}}^{-1}$,

where $\left[\mathrm{X}_{i}\right]$ is the concentration of a reactive species $(\mathrm{CO}$, $\mathrm{NO}_{2}, \mathrm{SO}_{2}$, VOCs, etc.) in ambient air, $k_{\mathrm{OH}+\mathrm{X}_{\mathrm{i}}}$ represents the corresponding bimolecular reaction rate constant, and $k_{\mathrm{OH}+\mathrm{X}_{i}} \cdot\left[\mathrm{X}_{i}\right]$ stands for the reactivity of $\mathrm{X}_{i}$. Observed $L_{\mathrm{OH}}$ values are between $1 \mathrm{~s}^{-1}$ in clean air and $200 \mathrm{~s}^{-1}$ in heavily polluted air in the atmospheric boundary layer (Lou et al., 2010 and references therein). The daytime average $\mathrm{OH}$ reactivity during IPAC-NC is estimated to be $44 \mathrm{~s}^{-1}$ at the surface, and 12, 8 and $6 \mathrm{~s}^{-1}$ at altitudes of $0.8,1.6$ and $2.4 \mathrm{~km}$, respectively. The total $\mathrm{OH}$ reactivity over Huabei estimated in this study is much higher than that in the lower atmosphere over the Pacific, where a median $L_{\mathrm{OH}}$ value of $4.0 \pm 1.0 \mathrm{~s}^{-1}$ was measured by aircraft during INTEX-B (Mao et al., 2009). Note that the total $\mathrm{OH}$ reactivity generally varies during the day (Sheehy et al., 2010; Lou et al., 2010). For example, surface $L_{\mathrm{OH}}$ in the PRD was observed to have a mean maximum value of $50 \mathrm{~s}^{-1}$ at daybreak and a mean minimum value of $20 \mathrm{~s}^{-1}$ at noon (Lou et al., 2010). About $35-45 \%$ of the total $\mathrm{OH}$ reactivity in IPAC-NC appears to come from reactions with VOCs. In contrast, previous studies indicated that the $\mathrm{OH}$ reactivity in polluted areas was dominated by organic compounds, e.g. $70 \%$ in MCMA $\left(19.4^{\circ} \mathrm{N}\right.$ latitude) during springtime (Shirley et al., 2006) and $85 \%$ in the PRD $\left(23.5^{\circ} \mathrm{N}\right.$ latitude) during summer (Lou et al., 2010).

The main source of $\mathrm{HO}_{2}$ over the polluted region of Huabei is the reaction of $\mathrm{OH}$ with $\mathrm{CO}(17-34 \%)$. In the upper part of the PBL and the lower FT, the contribution from photolysis of $\mathrm{CH}_{2} \mathrm{O}(9-16 \%)$ is also considerable. Again, we find that the reaction of $\mathrm{OH}$ with $\mathrm{SO}_{2}$ makes a substantial contribution (16-18\%) to the $\mathrm{HO}_{2}$ production in the upper part of the PBL and the lower FT. To our knowledge, such efficient recycling between $\mathrm{OH}$ and $\mathrm{HO}_{2}$ by $\mathrm{SO}_{2}$-related reactions was not found in previous studies. Kanaya et al. (2009) reported a much smaller $(3 \%)$ contribution of the reaction $\mathrm{SO}_{2}+\mathrm{OH}$ to the $\mathrm{HO}_{2}$ production over East China during the Mount Tai Experiment 2006. During IPAC-NC, the oxidation of VOCs contributed $\sim 75 \%$ to the $\mathrm{HO}_{2}$ production near the surface and $\sim 50-65 \%$ in the upper part of the PBL and the lower FT. As shown in Table 5, the reactions of peroxy radicals with $\mathrm{NO}$ are a major pathway to form $\mathrm{HO}_{2}$ from VOCs. The initial reactions of speciated VOCs that lead to the formation of these peroxy radicals are provided in the table note. Organic peroxy radicals are formed by the oxidation of hydrocarbons, and only a selection is shown. The degradation of the peroxy acetyl radicals $\mathrm{CH}_{3} \mathrm{CO}(\mathrm{OO}$.), formed mainly by the oxidation of $\mathrm{CH}_{3} \mathrm{CHO}$ by $\mathrm{OH}$, is a dominant formation pathway of $\mathrm{CH}_{3} \mathrm{O}_{2}(53 \%$ near the surface, $60 \%, 53 \%$ and $43 \%$ at $0.8 \mathrm{~km}, 1.6 \mathrm{~km}$ and $2.4 \mathrm{~km}$ altitudes, respectively). At the surface, about $30 \%$ of $\mathrm{CH}_{3} \mathrm{O}_{2}$ is attributed to the reactions of Criegee radicals $\left[\mathrm{CH}_{3} \mathrm{CHOO}\right]^{*}$, formed mainly by the addition reaction of 2-butene and propene by $\mathrm{O}_{3}$. The contribution from the reaction of $\mathrm{OH}$ with $\mathrm{CH}_{4}$ is only minor near the surface $(<10 \%)$, though increases considerably to $20-40 \%$ in the upper part of the PBL and the lower FT. It appears that the most important VOCs that convert $\mathrm{OH}$ to $\mathrm{HO}_{2}$ in the lower atmosphere over Huabei are aromatics (represented by m,p-xylene and toluene) and alkenes (represented by 2-butene and isobutene). Note that the oxidation of $\mathrm{m}, \mathrm{p}$-xylene and toluene also produces unsaturated dicarbonyls (e.g. $\mathrm{CHOCH}=\mathrm{CHCHO}$ ), which can form additional $\mathrm{HO}_{2}$ through photolysis or further reaction with $\mathrm{OH}$. The loss of $\mathrm{HO}_{2}$ over Huabei is mainly controlled by the reaction of $\mathrm{HO}_{2}$ with $\mathrm{NO}(>94 \%)$, which recycles $\mathrm{OH}$ very efficiently as described above.

Note that we take into account heterogeneous reactions of radicals including $\mathrm{OH}$ and $\mathrm{HO}_{2}$ on aerosol surfaces in our model simulations. The calculated pseudo first-order rate coefficient for the removal of $\mathrm{HO}_{2}$ by aerosol particles is $0.025 \mathrm{~s}^{-1}$ at the surface, and $0.018,0.010$ and $0.006 \mathrm{~s}^{-1}$ at altitudes of $0.8,1.6$ and $2.4 \mathrm{~km}$, respectively. Correspondingly, the concentrations of $\mathrm{HO}_{2}$ decrease by $8 \%$ at the surface and by $22 \%, 9 \%$ and $6 \%$ when heterogeneous reactions of radicals are included (BASE), compared to the model runs in which they were not included (NO_H), and the relative decreases of $\mathrm{OH}$ concentrations are similar. Kanaya et al. (2009) reported a larger effect of heterogeneous reactions on $\mathrm{HO}_{\mathrm{x}}$ radicals over East China during the Mount Tai Experiment in June 2006, with the daytime maximum concentrations decreasing by $26 \%$ (from $5.0 \times 10^{6}$ to $3.7 \times 10^{6}$ molecules $\mathrm{cm}^{-3}$ ) for $\mathrm{OH}$ and $41 \%$ (from 34 to 20 pptv) for $\mathrm{HO}_{2}$, respectively. They adopted a central value of the uptake coefficient of $0.25 \pm 0.09(n=10)$, measured in their laboratory, and estimated particle size distributions with observed mass concentrations of chemical species in 9 size bins between 0.43-9 $\mu \mathrm{m}$. Kanaya et al. (2009) estimated a typical surface area concentration of $6.3 \times 10^{2} \mu \mathrm{m}^{2} \mathrm{~cm}^{-3}$, much higher than our measurements during IPAC-NC, and a median pseudo first-order rate coefficient of $0.014 \mathrm{~s}^{-1}$ for the removal of $\mathrm{HO}_{2}$, comparable to our estimate at about $1 \mathrm{~km}$ altitude.

Regardless of the uptake coefficients and aerosol particle size distributions employed, the loss efficiency of $\mathrm{HO}_{2}$ is ultimately determined by the calculated pseudo first-order rate coefficient. With similar values of the pseudo first-order rate coefficient (e.g. about $0.015 \mathrm{~s}^{-1}$ at $1 \mathrm{~km}$ altitude over Huabei), the smaller effect of heterogeneous reactions on $\mathrm{HO}_{2}$ concentration estimated in this study $(\sim 20 \%)$ than by Kanaya et al. (2009) may be related to the difference in the treatment of intermediate VOC oxidation products between the two models. The chemical box model used by Kanaya et al. (2009) was based on the Regional Atmospheric Chemistry Mechanism (RACM) (Stockwell et al., 1997). RACM is a condensed mechanism, with a much smaller number of the intermediate VOC oxidation products (e.g. $\mathrm{CH}_{2} \mathrm{O}$ and 
Table 5. $\mathrm{HO}_{2}$ budget at different altitudes based on a model analysis of measurement data with and without considering heterogeneous reactions ( $\mathrm{HR}$ ) of $\mathrm{OH}$ and $\mathrm{HO}_{2}$ on aerosol surfaces.

\begin{tabular}{|c|c|c|c|c|c|c|c|c|}
\hline Item & \multicolumn{2}{|c|}{ Surface } & \multicolumn{2}{|c|}{$0.8 \mathrm{~km}$} & \multicolumn{2}{|c|}{$1.6 \mathrm{~km}$} & \multicolumn{2}{|c|}{$2.4 \mathrm{~km}$} \\
\hline Production (molec $\mathrm{cm}^{-3} \mathrm{~s}^{-1}$ ) & $2.2 \times 10^{8}$ & $2.3 \times 10^{8}$ & $8.0 \times 10^{7}$ & $9.7 \times 10^{8}$ & $3.6 \times 10^{7}$ & $3.8 \times 10^{7}$ & $1.9 \times 10^{7}$ & $2.0 \times 10^{7}$ \\
\hline $\mathrm{CO}+\mathrm{OH}$ & $22 \%$ & $22 \%$ & $34 \%$ & $35 \%$ & $19 \%$ & $19 \%$ & $17 \%$ & $17 \%$ \\
\hline $\mathrm{CH}_{3}(\mathrm{OO} \cdot)+\mathrm{NO}$ & $9 \%$ & $9 \%$ & $8 \%$ & $8 \%$ & $8 \%$ & $8 \%$ & $8 \%$ & $8 \%$ \\
\hline $\mathrm{C}_{6} \mathrm{H}_{3} \mathrm{CH}_{3}, \mathrm{HOH}, \mathrm{CH}_{3} /(\mathrm{OO} \cdot)+\mathrm{NO}$ & $9 \%$ & $9 \%$ & $1 \%$ & $1 \%$ & $3 \%$ & $2 \%$ & $2 \%$ & $2 \%$ \\
\hline $\mathrm{CH}_{2} \mathrm{O}+h v$ & $4 \%$ & $4 \%$ & $9 \%$ & $7 \%$ & $13 \%$ & $12 \%$ & $16 \%$ & $15 \%$ \\
\hline $\mathrm{C}_{6} \mathrm{H}_{4} \mathrm{CH}_{3}, \mathrm{HOH} /(\mathrm{OO} \cdot)+\mathrm{NO}$ & $3 \%$ & $3 \%$ & $1 \%$ & $1 \%$ & $<1 \%$ & $<1 \%$ & $<1 \%$ & $<1 \%$ \\
\hline $\mathrm{CH}_{2} \mathrm{O}+\mathrm{OH}$ & $3 \%$ & $3 \%$ & $7 \%$ & $7 \%$ & $6 \%$ & $6 \%$ & $6 \%$ & $6 \%$ \\
\hline $\mathrm{SO}_{2}+\mathrm{OH}$ & $3 \%$ & $3 \%$ & $17 \%$ & $17 \%$ & $16 \%$ & $17 \%$ & $18 \%$ & $18 \%$ \\
\hline $\mathrm{CH}_{3} \mathrm{C}(\mathrm{OH})\left(\mathrm{CH}_{3}\right) \mathrm{CH}_{2}(\mathrm{OO} \cdot)+\mathrm{NO}$ & $3 \%$ & $3 \%$ & $3 \%$ & $3 \%$ & $3 \%$ & $3 \%$ & $2 \%$ & $2 \%$ \\
\hline $\mathrm{CH}_{3} \mathrm{C}(\mathrm{OO} \cdot)\left(\mathrm{CH}_{3}\right) \mathrm{CH}_{2}(\mathrm{OH})+\mathrm{NO}$ & $3 \%$ & $3 \%$ & $3 \%$ & $3 \%$ & $3 \%$ & $3 \%$ & $2 \%$ & $2 \%$ \\
\hline $\mathrm{CHOCH}=\mathrm{C}\left(\mathrm{CH}_{3}\right) \mathrm{CO}(\mathrm{OO} \cdot)+\mathrm{NO}$ & $2 \%$ & $2 \%$ & $1 \%$ & $1 \%$ & $1 \%$ & $1 \%$ & $1 \%$ & $1 \%$ \\
\hline $\mathrm{CH}_{3} \mathrm{COCHO}+h v$ & $2 \%$ & $2 \%$ & $1 \%$ & $1 \%$ & $2 \%$ & $2 \%$ & $2 \%$ & $2 \%$ \\
\hline $\mathrm{CH}_{2}(\mathrm{OH}) \mathrm{CH}_{2}(\mathrm{OO} \cdot)+\mathrm{NO}$ & $2 \%$ & $2 \%$ & $<1 \%$ & $<1 \%$ & $<1 \%$ & $<1 \%$ & $<1 \%$ & $<1 \%$ \\
\hline $\mathrm{CHOCH}=\mathrm{C}\left(\mathrm{CH}_{3}\right) \mathrm{CHO}+h v$ & $1 \%$ & $1 \%$ & $<1 \%$ & $<1 \%$ & $1 \%$ & $1 \%$ & $1 \%$ & $1 \%$ \\
\hline $\mathrm{C}_{6} \mathrm{H}_{3} \mathrm{CH}_{3},(\mathrm{OH}) \mathrm{OH}, \mathrm{CH}_{3} /(\mathrm{OO} \cdot)+\mathrm{NO}$ & $1 \%$ & $1 \%$ & $<1 \%$ & $<1 \%$ & $<1 \%$ & $<1 \%$ & $<1 \%$ & $<1 \%$ \\
\hline $\mathrm{CH}_{3} \mathrm{COCOCHO}+h v$ & $1 \%$ & $1 \%$ & $<1 \%$ & $<1 \%$ & $1 \%$ & $1 \%$ & $1 \%$ & $<1 \%$ \\
\hline $\mathrm{CHOCH}=\mathrm{CHCO}(\mathrm{OO} \cdot)+\mathrm{NO}$ & $1 \%$ & $1 \%$ & $<1 \%$ & $<1 \%$ & $<1 \%$ & $<1 \%$ & $<1 \%$ & $<1 \%$ \\
\hline $\mathrm{C}_{9} \mathrm{H}_{12} \mathrm{CH}_{3}(\mathrm{OO} \cdot), \mathrm{H}(\mathrm{OH})+\mathrm{NO}$ & $1 \%$ & $1 \%$ & $<1 \%$ & $<1 \%$ & $7 \%$ & $7 \%$ & $7 \%$ & $7 \%$ \\
\hline $\mathrm{C}_{7} \mathrm{H}_{14}(\mathrm{OH})(\mathrm{OO} \cdot)+\mathrm{NO}$ & $1 \%$ & $1 \%$ & $<1 \%$ & $<1 \%$ & $1 \%$ & $1 \%$ & $1 \%$ & $1 \%$ \\
\hline $\mathrm{CHOCH}=\mathrm{CHCHO}+h v$ & $1 \%$ & $1 \%$ & $<1 \%$ & $<1 \%$ & $<1 \%$ & $<1 \%$ & $<1 \%$ & $<1 \%$ \\
\hline $\mathrm{C}_{6} \mathrm{H}_{6}+\mathrm{OH}$ & $1 \%$ & $1 \%$ & $<1 \%$ & $<1 \%$ & $<1 \%$ & $<1 \%$ & $<1 \%$ & $<1 \%$ \\
\hline $\mathrm{CH}_{2} \mathrm{O}+\mathrm{HO}_{2}$ & $<1 \%$ & $<1 \%$ & $1 \%$ & $1 \%$ & $1 \%$ & $1 \%$ & $1 \%$ & $1 \%$ \\
\hline $\mathrm{O}_{3}+\mathrm{HO}_{2}$ & $<1 \%$ & $<1 \%$ & $<1 \%$ & $<1 \%$ & $1 \%$ & $1 \%$ & $1 \%$ & $1 \%$ \\
\hline $\mathrm{HO}_{2}+\mathrm{HO}_{2}$ & $<1 \%$ & $<1 \%$ & $<1 \%$ & $1 \%$ & $<1 \%$ & $<1 \%$ & $<1 \%$ & $<1 \%$ \\
\hline remaining & $<1 \%$ & $<1 \%$ & $<1 \%$ & $<1 \%$ & $<1 \%$ & $<1 \%$ & $<1 \%$ & $<1 \%$ \\
\hline Concentration $\left(\right.$ molec $\left.\mathrm{cm}^{-3}\right)$ & $1.2 \times 10^{8}$ & $1.3 \times 10^{8}$ & $1.8 \times 10^{8}$ & $2.3 \times 10^{8}$ & $1.0 \times 10^{8}$ & $1.1 \times 10^{8}$ & $6.3 \times 10^{7}$ & $6.7 \times 10^{7}$ \\
\hline
\end{tabular}

$\mathrm{CH}_{3}\left(\mathrm{OO} \cdot\right.$ ), formed mainly by the initial reactions $\mathrm{CH}_{3} \mathrm{CHO}+\mathrm{OH}, \mathrm{CH}_{3} \mathrm{CH}=\mathrm{CHCH}_{3}+\mathrm{O}_{3}$ and $\mathrm{C}_{3} \mathrm{H}_{6}+\mathrm{O}_{3}$, and $\mathrm{CH}_{4}+\mathrm{OH}$.

$\mathrm{C}_{6} \mathrm{H}_{3} \mathrm{CH}_{3}, \mathrm{HOH}, \mathrm{CH}_{3} /(\mathrm{OO} \cdot)$, formed by the initial reaction $\mathrm{C}_{6} \mathrm{H}_{4} \mathrm{CH}_{3}, \mathrm{CH}_{3}+\mathrm{OH}$.

$\mathrm{CH}_{3} \mathrm{CH}(\mathrm{OH}) \mathrm{CH}(\mathrm{OO} \cdot) \mathrm{CH}_{3}$, formed by the initial reaction $\mathrm{CH}_{3} \mathrm{CH}=\mathrm{CHCH}_{3}+\mathrm{OH}$.

$\mathrm{C}_{6} \mathrm{H}_{4} \mathrm{CH}_{3}, \mathrm{HOH} /(\mathrm{OO} \cdot)$, formed by the initial reaction $\mathrm{C}_{6} \mathrm{H}_{5} \mathrm{CH}_{3}+\mathrm{OH}$.

$\mathrm{CH}_{3} \mathrm{C}(\mathrm{OH})\left(\mathrm{CH}_{3}\right) \mathrm{CH}_{2}(\mathrm{OO} \cdot)$, formed by the initial reaction $\mathrm{CH}_{3} \mathrm{C}\left(\mathrm{CH}_{3}\right)=\mathrm{CH}_{2}+\mathrm{OH}$.

$\mathrm{CH}_{3} \mathrm{C}(\mathrm{OO} \cdot)\left(\mathrm{CH}_{3}\right) \mathrm{CH}_{2}(\mathrm{OH})$, formed by the initial reaction $\mathrm{CH}_{3} \mathrm{C}\left(\mathrm{CH}_{3}\right)=\mathrm{CH}_{2}+\mathrm{OH}$.

$\mathrm{CH}_{3} \mathrm{CH}(\mathrm{OO} \cdot) \mathrm{CH}_{2}(\mathrm{OH})$, formed by the initial reaction $\mathrm{C}_{3} \mathrm{H}_{6}+\mathrm{OH}$.

$\mathrm{CH}_{3} \mathrm{COCH}=\mathrm{CHCO}(\mathrm{OO} \cdot)$, formed by the initial reactions $\mathrm{CH}_{3} \mathrm{COCH}=\mathrm{CHCHO}+\mathrm{h} v$ and $\mathrm{CH}_{3} \mathrm{COCH}=\mathrm{CHCHO}+\mathrm{OH}$.

$\mathrm{CHOCH}=\mathrm{C}\left(\mathrm{CH}_{3}\right) \mathrm{CO}(\mathrm{OO} \cdot)$, formed by the initial reactions $\mathrm{CHOCH}=\mathrm{C}\left(\mathrm{CH}_{3}\right) \mathrm{CHO}+\mathrm{OH}$ and $\mathrm{CHOCH}=\mathrm{C}\left(\mathrm{CH}_{3}\right) \mathrm{CHO}+h v$.

$\mathrm{CH}_{2}(\mathrm{OH}) \mathrm{CH}_{2}(\mathrm{OO} \cdot)$, formed by the initial reaction $\mathrm{C}_{2} \mathrm{H}_{4}+\mathrm{OH}$

$\mathrm{C}_{6} \mathrm{H}_{3} \mathrm{CH}_{3},(\mathrm{OH}) \mathrm{OH}, \mathrm{CH}_{3} /(\mathrm{OO} \cdot)$, formed by the initial reaction $\mathrm{C}_{6} \mathrm{H}_{3} \mathrm{CH}_{3}, \mathrm{OH}, \mathrm{CH}_{3}+\mathrm{OH}$.

$\mathrm{CHOCH}=\mathrm{CHCO}(\mathrm{OO} \cdot)$, formed by the initial reaction $\mathrm{CHOCH}=\mathrm{CHCHO}+\mathrm{OH}$ and $\mathrm{CHOCH}=\mathrm{CHCHO}+h v$.

$\mathrm{C}_{9} \mathrm{H}_{12} \mathrm{CH}_{3}(\mathrm{OO} \cdot) \cdot \mathrm{H}(\mathrm{OH})$, formed by the initial reaction $\mathrm{C}_{9} \mathrm{H}_{13} \mathrm{CH}_{3}+\mathrm{OH}$

$\mathrm{C}_{7} \mathrm{H}_{14}(\mathrm{OH})(\mathrm{OO} \cdot)$, formed by the initial reaction $\mathrm{C}_{7} \mathrm{H}_{16}+\mathrm{OH}$.

$\mathrm{CH}_{3} \mathrm{CH}(\mathrm{OH}) \mathrm{CH}_{2}(\mathrm{OO} \cdot)$, formed by the initial reaction $\mathrm{C}_{3} \mathrm{H}_{6}+\mathrm{OH}$.

$\mathrm{CH}_{3} \mathrm{CH}_{2}\left(\mathrm{OO}\right.$.), formed by the initial reactions $\mathrm{CH}_{3} \mathrm{CH}\left(\mathrm{CH}_{3}\right) \mathrm{CH}_{2} \mathrm{CH}_{3}+\mathrm{OH}, \mathrm{CH}_{3} \mathrm{CH}_{2} \mathrm{CH}_{2} \mathrm{CH}_{3}+\mathrm{OH}$, and $\mathrm{C}_{2} \mathrm{H}_{6}+\mathrm{OH}$.

$\mathrm{C}_{6} \mathrm{H}_{5}(\mathrm{OH}) \mathrm{OH} /(\mathrm{OO} \cdot)$, formed by the initial reactions $\mathrm{CH}_{3} \mathrm{CH}\left(\mathrm{CH}_{3}\right) \mathrm{CH}_{2} \mathrm{CH}_{3}+\mathrm{OH}, \mathrm{CH}_{3} \mathrm{CH}_{2} \mathrm{CH}_{2} \mathrm{CH}_{3}+\mathrm{OH}$, and $\mathrm{C}_{2} \mathrm{H}_{6}+\mathrm{OH}$.

$\mathrm{CH}_{2}(\mathrm{OO} \cdot)$, formed by the initial reactions $\mathrm{CH}_{3} \mathrm{COCOCHO}+h v, \mathrm{CH}_{3} \mathrm{C}\left(\mathrm{CH}_{3}\right)=\mathrm{CH}_{2}+\mathrm{O}_{3}, \mathrm{C}_{3} \mathrm{H}_{6}+\mathrm{O}_{3}$, and $\mathrm{C}_{2} \mathrm{H}_{4}+\mathrm{O}_{3}$. 
Table 6. Ozone budget at different altitudes based on a model analysis of measurement data with and without considering heterogeneous reactions (HR) of $\mathrm{OH}$ and $\mathrm{HO}_{2}$ on aerosol surfaces.

\begin{tabular}{|c|c|c|c|c|c|c|c|c|}
\hline \multirow[t]{2}{*}{ Item } & \multicolumn{2}{|c|}{ Surface } & \multicolumn{2}{|c|}{$0.8 \mathrm{~km}$} & \multicolumn{2}{|c|}{$1.6 \mathrm{~km}$} & \multicolumn{2}{|c|}{$2.4 \mathrm{~km}$} \\
\hline & HR & NO_HR & HR & NO_HR & HR & NO_HR & HR & NO_HR \\
\hline Production $\left(\mathrm{ppbv}^{-1}\right)$ & 48.3 & 51.6 & 15.5 & 19.6 & 8.4 & 9.3 & 4.9 & 5.3 \\
\hline $\mathrm{NO}+\mathrm{HO}_{2}$ & $65 \%$ & $65 \%$ & $74 \%$ & $75 \%$ & $67 \%$ & $68 \%$ & $70 \%$ & $70 \%$ \\
\hline $\mathrm{CH}_{3}(\mathrm{OO} \cdot)+\mathrm{NO}$ & $6 \%$ & $6 \%$ & $6 \%$ & $6 \%$ & $6 \%$ & $5 \%$ & $6 \%$ & $6 \%$ \\
\hline $\mathrm{CH}_{3} \mathrm{CH}(\mathrm{OH}) \mathrm{CH}(\mathrm{OO} \cdot) \mathrm{CH}_{3}+\mathrm{NO}$ & $5 \%$ & $5 \%$ & $1 \%$ & $1 \%$ & $<1 \%$ & $<1 \%$ & $<1 \%$ & $<1 \%$ \\
\hline $\mathrm{CH}_{3} \mathrm{CO}(\mathrm{OO} \cdot)+\mathrm{NO}$ & $3 \%$ & $3 \%$ & $4 \%$ & $4 \%$ & $3 \%$ & $3 \%$ & $2 \%$ & $2 \%$ \\
\hline $\mathrm{C}_{6} \mathrm{H}_{3} \mathrm{CH}_{3}, \mathrm{HOH}, \mathrm{CH}_{3} /(\mathrm{OO} \cdot)+\mathrm{NO}$ & $2 \%$ & $2 \%$ & $1 \%$ & $1 \%$ & $1 \%$ & $1 \%$ & $1 \%$ & $1 \%$ \\
\hline $\mathrm{CH}_{3} \mathrm{C}(\mathrm{OO} \cdot)\left(\mathrm{CH}_{3}\right) \mathrm{CH}_{2}(\mathrm{OH})+\mathrm{NO}$ & $2 \%$ & $2 \%$ & $2 \%$ & $2 \%$ & $2 \%$ & $2 \%$ & $2 \%$ & $2 \%$ \\
\hline $\mathrm{CH}_{3} \mathrm{C}(\mathrm{OH})\left(\mathrm{CH}_{3}\right) \mathrm{CH}_{2}(\mathrm{OO} \cdot)+\mathrm{NO}$ & $2 \%$ & $2 \%$ & $2 \%$ & $2 \%$ & $2 \%$ & $2 \%$ & $2 \%$ & $2 \%$ \\
\hline $\mathrm{CH}_{3} \mathrm{COCH}=\mathrm{CHCO}(\mathrm{OO} \cdot)+\mathrm{NO}$ & $2 \%$ & $2 \%$ & $1 \%$ & $1 \%$ & $<1 \%$ & $<1 \%$ & $1 \%$ & $1 \%$ \\
\hline $\mathrm{C}_{9} \mathrm{H}_{12}\left(\mathrm{CH}_{3}\right)(\mathrm{OO} \cdot) \mathrm{H}(\mathrm{OH})+\mathrm{NO}$ & $1 \%$ & $1 \%$ & $<1 \%$ & $<1 \%$ & $5 \%$ & $5 \%$ & $5 \%$ & $5 \%$ \\
\hline $2 \mathrm{t} 91+\mathrm{NO}$ & $<1 \%$ & $<1 \%$ & $<1 \%$ & $<1 \%$ & $2 \%$ & $2 \%$ & $2 \%$ & $2 \%$ \\
\hline remaining & $<12 \%$ & $<12 \%$ & $<9 \%$ & $<8 \%$ & $<12 \%$ & $<12 \%$ & $<9 \%$ & $<9 \%$ \\
\hline Loss $\left(p p b v h^{-1}\right)$ & 8.5 & 9.1 & 2.8 & 3.2 & 1.7 & 1.9 & 1.2 & 1.3 \\
\hline $\mathrm{NO}_{2}+\mathrm{OH}$ & $69 \%$ & $70 \%$ & $66 \%$ & $70 \%$ & $62 \%$ & $63 \%$ & $68 \%$ & $69 \%$ \\
\hline $\mathrm{CH}_{3} \mathrm{CH}=\mathrm{CHCH}_{3}+\mathrm{O}_{3}$ & $16 \%$ & $15 \%$ & $1 \%$ & $1 \%$ & $<1 \%$ & $<1 \%$ & $<1 \%$ & $<1 \%$ \\
\hline $\mathrm{O}_{3}+$ surface & $8 \%$ & $7 \%$ & $15 \%$ & $13 \%$ & $14 \%$ & $13 \%$ & $10 \%$ & $10 \%$ \\
\hline $\mathrm{H}_{2} \mathrm{O}+\mathrm{O}\left({ }^{1} \mathrm{D}\right)$ & $3 \%$ & $3 \%$ & $13 \%$ & $12 \%$ & $13 \%$ & $12 \%$ & $11 \%$ & $11 \%$ \\
\hline $\mathrm{C}_{9} \mathrm{H}_{13} \mathrm{CH}_{3}+\mathrm{O}_{3}$ & $1 \%$ & $1 \%$ & $<1 \%$ & $<1 \%$ & $6 \%$ & $6 \%$ & $5 \%$ & $5 \%$ \\
\hline $\mathrm{O}_{3}+\mathrm{HO}$ & $1 \%$ & $1 \%$ & $2 \%$ & $2 \%$ & $2 \%$ & $2 \%$ & $2 \%$ & $3 \%$ \\
\hline $\mathrm{O}_{3}+\mathrm{HO}_{2}$ & $1 \%$ & $1 \%$ & $2 \%$ & $1 \%$ & $2 \%$ & $2 \%$ & $1 \%$ & $1 \%$ \\
\hline remaining & $<1 \%$ & $<2 \%$ & $<1 \%$ & $<1 \%$ & $<1 \%$ & $<2 \%$ & $<3 \%$ & $<1 \%$ \\
\hline Net production $\left(\mathrm{ppbv} \mathrm{h}^{-1}\right)$ & 39.7 & 42.5 & 12.7 & 16.3 & 6.7 & 7.4 & 3.7 & 4.0 \\
\hline
\end{tabular}

2t91: $\mathrm{CH}_{3} \mathrm{CO}^{\prime} \mathrm{CH}^{\prime} \mathrm{CH}_{2}{ }^{\prime} \mathrm{CH}\left(\mathrm{CH}_{2} \mathrm{OO} \cdot\right)^{\prime} \mathrm{CCH}_{3} \mathrm{CH}_{3}$.

lumped species ALD, KET and MACR) than the NCAR Master Mechanism. The more complex intermediate VOC oxidation products were prescribed in their model simulations and kept constant from the reference to the sensitivity simulations (Kanaya et al., 2009). In our model simulations, all (a few hundred) intermediate VOC oxidation products, except for $\mathrm{CH}_{2} \mathrm{O}$ and $\mathrm{CH}_{3} \mathrm{OH}$, were simulated to attain steady state between production and loss, the latter also including heterogeneous reactions of these compounds. Compared to the standard simulations (BASE), the sensitivity simulations without heterogeneous reactions of $\mathrm{OH}$ and $\mathrm{HO}_{2}$ (NO_H) attained a new steady state with different concentrations of the intermediate VOC oxidation products. For example, the mixing ratio of $\mathrm{CH}_{3} \mathrm{COCHO}$ at $0.8 \mathrm{~km}$ altitude is $0.45 \mathrm{ppbv}$ in BASE and $0.54 \mathrm{ppbv}$ in $\mathrm{NO} H$, respectively. Such differences in the intermediate VOC oxidation products can reduce the changes in simulated $\mathrm{OH}$ and $\mathrm{HO}_{2}$ relative to the simulations with fixed concentrations.

De Reus et al. (2005) investigated the effect of heterogeneous removal of $\mathrm{HO}_{2}$ on Saharan dust particles on the $\mathrm{RO}_{\mathrm{x}}$ $\left(\mathrm{HO}_{2}+\mathrm{RO}_{2}\right)$ mixing ratio applying an uptake coefficient of 0.2 , the same as used in this study. They focused on relatively long-lived trace gases with the initial conditions from measurements and showed that heterogeneous removal of $\mathrm{HO}_{2}$ causes only a small decrease in $\mathrm{RO}_{\mathrm{x}}$, with the calculated-to- observed ratio of $\mathrm{RO}_{\mathrm{x}}$ decreasing from 1.38 in the simulation without heterogeneous removal reactions to 1.30 in the simulation with heterogeneous removal of $\mathrm{HO}_{2}$ (de Reus et al., 2005). In addition to the direct heterogeneous loss rate, the changes in $\mathrm{OH}$ and $\mathrm{HO}_{2}$ reflect other chemical characteristics. As presented above, we estimate a smaller decrease in $\mathrm{OH}$ and $\mathrm{HO}_{2}$ at the surface $(8 \%)$ compared to $0.8 \mathrm{~km}$ altitude $(22 \%)$, with a higher first-order rate coefficient for the removal of $\mathrm{HO}_{2}$ at the surface $\left(0.025 \mathrm{~s}^{-1}\right)$ than at $0.8 \mathrm{~km}$ $\left(0.018 \mathrm{~s}^{-1}\right)$. This suggests that the atmosphere over Huabei has a stronger capacity to buffer the perturbations on $\mathrm{HO}_{\mathrm{x}}$ near the surface than in the upper part of the PBL, most probably due to higher VOC concentrations.

The reasons for the relatively high $\mathrm{HO}_{\mathrm{x}}$ radical levels in the lower atmosphere over Huabei are intricate. It appears that the effective photolysis of ozone combined with the reactions of $\mathrm{OH}$ with $\mathrm{NO}_{2}, \mathrm{CO}$ and $\mathrm{SO}_{2}$ play an important role. First, the effective photolysis of ozone (determined by the reaction $\mathrm{H}_{2} \mathrm{O}+\mathrm{O}\left({ }^{1} \mathrm{D}\right)$ ), which acts as a primary source of $\mathrm{HO}_{\mathrm{x}}$, has a maximum at $0.8 \mathrm{~km}$ altitude. The calculated reaction rate of $\mathrm{H}_{2} \mathrm{O}+\mathrm{O}\left({ }^{1} \mathrm{D}\right)$ is $3.7 \times 10^{6}$ molecules $\mathrm{cm}^{-3} \mathrm{~s}^{-1}$ at the surface, and $4.6 \times 10^{6}$, $2.7 \times 10^{6}$ and $1.5 \times 10^{6}$ molecules $\mathrm{cm}^{-3} \mathrm{~s}^{-1}$ at altitudes of $0.8,1.6$ and $2.4 \mathrm{~km}$, respectively. Second, with respect to the fractional contribution to the $\mathrm{OH}$ loss rate, the reaction 
$\mathrm{CO}+\mathrm{OH}$ (which recycles $\mathrm{HO}_{2}$ ) has a maximum $(33 \%)$ and the reaction $\mathrm{NO}_{2}+\mathrm{OH}$ (which acts as a primary sink of $\mathrm{HO}_{\mathrm{x}}$ ) a minimum $(14 \%)$ at $0.8 \mathrm{~km}$. Third, the relative importance of other species, such as $\mathrm{CH}_{2} \mathrm{O}$ and $\mathrm{SO}_{2}$, also changes with altitude. The calculated reaction rate of $\mathrm{SO}_{2}+\mathrm{OH}$ is $6.7 \times 10^{6}$ molecules $\mathrm{cm}^{-3} \mathrm{~s}^{-1}$ at the surface, and $1.3 \times 10^{7}$, $5.8 \times 10^{6}$ and $3.4 \times 10^{6}$ molecules $\mathrm{cm}^{-3} \mathrm{~s}^{-1}$ at altitudes of $0.8,1.6$ and $2.4 \mathrm{~km}$, respectively, with a maximum at $0.8 \mathrm{~km}$. $\mathrm{CO}$ and $\mathrm{SO}_{2}$ also compete with $\mathrm{NO}_{2}$ to react with $\mathrm{OH}$, recycling $\mathrm{HO}_{2}$ without the loss of total $\mathrm{HO}_{\mathrm{x}}$. VOC oxidation can play an important role in recycling $\mathrm{OH}$, sustaining the atmospheric oxidation capacity and amplifying trace gas removal in the troposphere (Lelieveld et al., 2008; Hofzumahaus et al., 2009). The effects of VOC oxidation on the $\mathrm{HO}_{\mathrm{x}}$ budget deserve scrutiny and will be detailed in future work, for example, to study the role of aromatics in $\mathrm{HO}_{\mathrm{x}}$ recycling.

\subsection{Ozone formation}

Figure $12 \mathrm{c}$ presents the vertical profile of net ozone production over the polluted region of Huabei calculated with the chemical box model (see Sect. 2.2). Table 6 presents an overview of the most relevant reactions for the ozone budget. As in previous studies (e.g. Liu et al., 1987; Ma et al., 2002b; Lu et al., 2010), the total oxidant $\left(\mathrm{O}_{x} \equiv \mathrm{O}_{3}+\mathrm{NO}_{2}\right)$ is used to infer instantaneous photochemical production, $P\left(\mathrm{O}_{3}\right)$, and loss, $L\left(\mathrm{O}_{3}\right)$, of ozone.

$$
\begin{aligned}
& P\left(\mathrm{O}_{3}\right)=k_{7} \cdot\left[\mathrm{HO}_{2}\right] \cdot[\mathrm{NO}]+\sum k_{6} \cdot\left[\mathrm{RO}_{2}\right] \cdot[\mathrm{NO}] \\
& L\left(\mathrm{O}_{3}\right)=k_{1} \cdot\left[\mathrm{O}\left({ }^{1} \mathrm{D}\right)\right] \cdot\left[\mathrm{H}_{2} \mathrm{O}\right]+k_{9} \cdot\left[\mathrm{HO}_{2}\right] \cdot\left[\mathrm{O}_{3}\right]+k_{10} \\
& \cdot[\mathrm{OH}] \cdot\left[\mathrm{O}_{3}\right]+\sum k_{11} \cdot[\text { alkene }] \cdot\left[\mathrm{O}_{3}\right]+k_{12} \cdot\left[\mathrm{NO}_{2}\right] \cdot[\mathrm{OH}]
\end{aligned}
$$

The calculated $P\left(\mathrm{O}_{3}\right)$ in the lower atmosphere over Huabei is $48 \mathrm{ppbv} \mathrm{h}^{-1}$ at the surface, and 16,8 and $5 \mathrm{ppbv} \mathrm{h}^{-1}$ at altitudes of $0.8,1.6$ and $2.4 \mathrm{~km}$, respectively. The recycling of $\mathrm{OH}$ through the reaction of $\mathrm{HO}_{2}$ with $\mathrm{NO}$ and the associated photolysis of $\mathrm{NO}_{2}$ is the main process $(65-74 \%)$ leading to ozone formation, followed by the reaction of $\mathrm{CH}_{3} \mathrm{O}_{2}$ with NO $(\sim 6 \%)$. The calculated $L\left(\mathrm{O}_{3}\right)$ is $9 \mathrm{ppbvh}^{-1}$ at the surface, and 3, 2 and $1 \mathrm{ppbv} \mathrm{h}^{-1}$ at altitudes of $0.8,1.6$ and $2.4 \mathrm{~km}$, respectively. The reaction of $\mathrm{NO}_{2}$ with $\mathrm{OH}$ is the dominant ozone loss process $(62-70 \%)$. At the surface $\sim 16 \%$ of $\mathrm{O}_{3}$ loss is attributed to its reaction with 2-butene. At higher altitudes, the effective photolysis of $\mathrm{O}_{3}$ becomes more important, contributing $11-13 \%$ to $L\left(\mathrm{O}_{3}\right)$. It is estimated that $8-15 \%$ of the $\mathrm{O}_{3}$ loss is due to its reaction on aerosol surfaces.

The calculated near-surface rate of $P\left(\mathrm{O}_{3}\right)$ during IPAC$\mathrm{NC}$ is comparable to the maximum $P\left(\mathrm{O}_{3}\right)\left(50 \mathrm{ppbv} \mathrm{h}^{-1}\right)$ at a suburban location near Beijing reported by Lu et al. (2010). Our $P\left(\mathrm{O}_{3}\right)$ and $P\left(\mathrm{O}_{3}\right)-L\left(\mathrm{O}_{3}\right)$ rates at higher altitudes (e.g. 9.3-5.3 and 7.4-4.0 $\mathrm{ppbvh}^{-1}$ at $1.6-2.4 \mathrm{~km}$ in the case of NO_HR) are comparable to the daytime 6-h average $P\left(\mathrm{O}_{3}\right)$ and $P\left(\mathrm{O}_{3}\right)-L\left(\mathrm{O}_{3}\right)$ values $\left(7.9\right.$ and $\left.6.4 \mathrm{ppbv} \mathrm{h}^{-1}\right)$ over East China during the Mount Tai Experiment 2006 (Kanaya et al., 2009). Kanaya et al. (2009) showed that the heterogeneous loss of $\mathrm{HO}_{2}$ on aerosols reduced the daytime 6-h average net ozone production rate, $P\left(\mathrm{O}_{3}\right)-L\left(\mathrm{O}_{3}\right)$, by $2.1 \mathrm{ppbvh}^{-1}$ (from $6.4 \mathrm{ppbvh}^{-1}$ ). Our model sensitivity runs show a smaller effect, with $P\left(\mathrm{O}_{3}\right)-L\left(\mathrm{O}_{3}\right)$ decreasing to $6.7 \mathrm{ppbv} \mathrm{h}^{-1}$ from $7.4 \mathrm{ppbv} \mathrm{h}^{-1}$ (by $0.7 \mathrm{ppbv} \mathrm{h}^{-1}$ ) at $1.6 \mathrm{~km}$ altitude. Our results suggest that the net ozone production in the lower atmosphere over Huabei during IPAC-NC (e.g. $16 \mathrm{ppbvh}^{-1}$ at $0.8 \mathrm{~km}$ ) is much higher than the average of $>5 \mathrm{ppbv} \mathrm{d}^{-1}$ (at $800 \mathrm{hPa}$ ) over the polluted part of the Asian continent during INTEX-B, as simulated with a global model by Zhang et al. (2008a).

At high $\mathrm{NO}_{\mathrm{x}}$ levels, e.g. over the polluted Huabei region, the photochemical ozone buildup is limited by radical formation and thus by the oxidation of $\mathrm{CO}$ and VOCs. As discussed above, $P\left(\mathrm{O}_{3}\right)$ in the lower atmosphere over Huabei is dominated by the reaction of $\mathrm{HO}_{2}$ with $\mathrm{NO}$ (by 65-74\%), and the production of $\mathrm{HO}_{2}$ is dominated by the reaction of $\mathrm{CO}$ with $\mathrm{OH}(17-34 \%)$. Therefore, we estimate that the oxidation of $\mathrm{CO}$ makes contributions to $P\left(\mathrm{O}_{3}\right)$ by $14 \%$ $\left(\sim 6.7 \mathrm{ppbv} \mathrm{h}^{-1}\right)$ at the surface, and $25 \%\left(\sim 3.8 \mathrm{ppbvh}^{-1}\right)$, $13 \%\left(\sim 1.1 \mathrm{ppbv} \mathrm{h}^{-1}\right)$ and $12 \%\left(\sim 0.6 \mathrm{ppbv} \mathrm{h}^{-1}\right)$ at altitudes of $0.8,1.6$ and $2.4 \mathrm{~km}$, respectively. The contribution of the reaction $\mathrm{NO}+\mathrm{HO}_{2}$ to $P\left(\mathrm{O}_{3}\right)$ is greatest $(74 \%)$ at $0.8 \mathrm{~km}$, where the reaction $\mathrm{SO}_{2}+\mathrm{OH}$ adds $17 \%$ to the $\mathrm{HO}_{2}$ production. This indicates that the oxidation of $\mathrm{SO}_{2}$ strongly augments ozone formation (up to $\sim 13 \%$ or $2.0 \mathrm{ppbv} \mathrm{h}^{-1}$ at $0.8 \mathrm{~km}$ ) in the lower atmosphere over Huabei. The oxidation of VOCs contributes most strongly to $P\left(\mathrm{O}_{3}\right)$ near the surface, by $\sim 85 \%$, of which $\sim 50 \%$ through the reaction $\mathrm{HO}_{2}+\mathrm{NO}$ and $\sim 35 \%$ through $\mathrm{RO}_{2}+\mathrm{NO}$. At higher altitudes, the contribution of VOCs to $P\left(\mathrm{O}_{3}\right)$ is $60-75 \%$, of which about 35$45 \%$ through $\mathrm{HO}_{2}+\mathrm{NO}$ and $25-30 \%$ through $\mathrm{RO}_{2}+\mathrm{NO}$.

It has been shown previously that high $\mathrm{OH}$ levels can substantially affect condensation rates onto aerosol particles (Robinson et al., 2007; Ma et al., 2010). In the highly oxidative atmospheric environment over Huabei, primary gaseous pollutants, such as $\mathrm{SO}_{2}, \mathrm{NO}_{2}$ and VOCs, are efficiently converted into less volatile species, such as sulfuric, nitric and organic acids, that can partition into the condensed phase. We calculate the condensation rates of these species with the chemical box model, constrained by the measurements, assuming steady state between their chemical production and loss. Since we do not account for gas-particle partitioning as a function of aerosol composition and ambient conditions (Farina et al., 2010), these estimates represent upper limits of the condensation rates (called condensation potential). Considering the low volatility of sulfuric acid, this potential approximates the actual condensation rate. The condensation potential of sulfuric acid is estimated to be $2-8 \mu \mathrm{g} \mathrm{cm}^{-3} \mathrm{~h}^{-1}$, with a peak value at an altitude of $0.8 \mathrm{~km}$. During IPAC$\mathrm{NC}$, the average mass concentration of sulfate in $\mathrm{PM}_{10}$ measured by aircraft was $9 \mu \mathrm{g} \mathrm{cm}^{-3}$ (Ma et al., 2010). This indicates that it takes a few hours for the gas-phase chemical 
transformation mechanisms to produce the amount of sulfate in aerosols sampled during IPAC-NC.

\section{Summary and conclusions}

We have analyzed the chemical properties of air pollution over the Huabei region in eastern China, using the measurement data obtained during the IPAC-NC field campaign in spring 2006. Huabei includes two megacities, i.e. Beijing and Tianjin, and several large industrial areas, e.g. Tangshan, Shijiazhuang and Taiyuan. High pollution emissions, together with the meteorological conditions that favor local convergence, result in the accumulation of pollutants in the lower atmosphere over the central area of Huabei. In addition to high concentrations of gaseous pollutants and haze particles, we deduce high levels of $\mathrm{HO}_{\mathrm{x}}$ radicals and active photochemistry in the lower atmosphere over the region, leading to the efficient formation of ozone and secondary aerosols. The results thus indicate that the lower atmosphere over Huabei is not only highly polluted but also acts as an oxidation pool over this part of China.

During IPAC-NC, daytime mean near-surface concentrations and standard deviations of the primary gaseous pollutants $\mathrm{SO}_{2}, \mathrm{NO}, \mathrm{NO}_{\mathrm{x}}, \mathrm{CO}$, and NMHCs were $24.7 \pm 20.9 \mathrm{ppbv}, 8.4 \pm 15.6 \mathrm{ppbv}, 29.4 \pm 23.1 \mathrm{ppbv}$, $1.5 \pm 1.0 \mathrm{ppmv}$, and $55.1 \pm 45.7 \mathrm{ppbv}$, respectively, in the polluted rural area of Huabei. Airborne measurements show that throughout the PBL and in the lower free troposphere the levels of these pollutants were also high. We observed widespread, high $\mathrm{SO}_{2}$ mixing ratios, typically $20-40 \mathrm{ppbv}$ at $0.5-1.5 \mathrm{~km}$ and $10-30 \mathrm{ppbv}$ at $1.5-3.0 \mathrm{~km}$ altitude. Over the most highly polluted areas, $\mathrm{SO}_{2}$ reached up to $60-100 \mathrm{ppbv}$ in the PBL, much higher than at the surface owing to the predominantly elevated sources by industrial stacks. Average $\mathrm{CO}$ during the campaign period was $\sim 0.7 \mathrm{ppmv}$ at $0.5-1.5 \mathrm{~km}$ altitude, and very high $\mathrm{CO}$ mixing ratios of $\sim 1$ ppmv were observed during some flights, and even higher levels at the surface. The $\mathrm{SO}_{2}$ in the lower atmosphere over Huabei observed during IPAC-NC is a few times higher than measured over an area in the northeastern part of China during April 2005, i.e. outside of the core pollution pool, and an order of magnitude higher than over the NE United States (Dickerson et al., 2007).

Our chemical box-model simulations, constrained by the measurements, suggest a maximum in the vertical profiles of $\mathrm{OH}$ and $\mathrm{HO}_{2}$ at an altitude of $\sim 1 \mathrm{~km}$ over the polluted area of Huabei. The peak $\mathrm{OH}$ concentration is estimated to be $6.9-8.5 \times 10^{6}$ molecules $\mathrm{cm}^{-3}(0.29$ $0.36 \mathrm{pptv})$, substantially higher than the surface level of 5.4$6.0 \times 10^{6}$ molecules $\mathrm{cm}^{-3}(0.22-0.24 \mathrm{pptv})$. It is shown that the combined effective photolysis of ozone and the recycling of radicals in the photochemistry of $\mathrm{NO}_{2}, \mathrm{CO}, \mathrm{VOC}$ and $\mathrm{SO}_{2}$ lead to high levels of $\mathrm{HO}_{\mathrm{x}}$ radicals in the lower atmosphere over Huabei. At the surface, high concentrations of $\mathrm{NO}_{2}$ suppress the recycling of $\mathrm{HO}_{\mathrm{x}}$ radicals by the termination reaction $\mathrm{NO}_{2}+\mathrm{OH}$. In contrast, at higher altitudes within the $\mathrm{PBL}, \mathrm{CO}$ and $\mathrm{SO}_{2}$ more effectively compete with relatively less $\mathrm{NO}_{2}$ to react with $\mathrm{OH}$, recycling $\mathrm{HO}_{2}$ more efficiently without a loss of total $\mathrm{HO}_{\mathrm{x}}$. OH levels in the lower atmosphere over Huabei appear to be similar to those over the Gulf of Mexico and 2-3 times higher than over the subtropical Pacific (Singh et al., 2009). The relatively high OH concentrations in the lower atmosphere over Huabei indicate that primary pollutants are oxidized more efficiently in Huabei than over the Pacific towards North America, promoting the formation of ozone and secondary aerosols in the region.

At the high $\mathrm{NO}_{\mathrm{x}}$ levels over Huabei, photochemical ozone formation is limited by the radical abundance and the oxidation rates of $\mathrm{CO}$ and VOCs. We estimate that the contribution of VOCs to instantaneous ozone production over Huabei, $P\left(\mathrm{O}_{3}\right)$, is $\sim 85 \%$ near the surface and $60-75 \%$ at higher altitudes in the PBL and lower free troposphere. The oxidation of $\mathrm{CO}$ contributes about $14 \%$ to $P\left(\mathrm{O}_{3}\right)$ at the surface and $12-$ $25 \%$ aloft. Interestingly, we find that the oxidation of $\mathrm{SO}_{2}$ also contributes significantly (up to $\sim 13 \%$ or $2.0 \mathrm{ppbv} \mathrm{h}^{-1}$ at $0.8 \mathrm{~km})$ to ozone production. The estimated $P\left(\mathrm{O}_{3}\right)$ rate at the surface during IPAC-NC is $48 \mathrm{ppbv} \mathrm{h}^{-1}$, comparable to the high maximum value of $50 \mathrm{ppbv} \mathrm{h}^{-1}$ at a suburban site of Beijing reported by Lu et al. (2010). Ozone production in the PBL over Huabei (e.g. 16 ppbv h$^{-1}$ at $0.8 \mathrm{~km}$ ) appears to be much higher than that over the polluted Asian continent during INTEX-B ( $>5 \mathrm{ppbv} \mathrm{d}^{-1}$ at $\left.800 \mathrm{hPa}\right)$, derived from simulations by Zhang et al. (2008a) using a global model. Note that the IPAC-NC and INTEX-B campaigns were performed in the same period, i.e. spring 2006.

The high $\mathrm{OH}$ levels tend to promote the formation of semiand low-volatile species such as inorganic and organic acids through the oxidation of $\mathrm{SO}_{2}, \mathrm{NO}_{2}$ and VOCs. In spring, the atmospheric load of primary aerosols over Huabei is very high due to strong emissions from both natural and anthropogenic sources (e.g. dust and black carbon), providing a large surface area for the condensation of these oxidation products. The condensation rate of sulfuric acid is estimated to be $2-8 \mu \mathrm{g} \mathrm{cm}^{-3} \mathrm{~h}^{-1}$ during IPAC-NC, with a maximum at about $0.8 \mathrm{~km}$ altitude. The interactions between pollution emissions, photochemistry, the atmospheric oxidation capacity and haze formation are intricate and require continued investigations.

Acknowledgements. This work was supported by the NSFC projects $40433008,40775073 \& 41075095$. The research leading to these results has received funding from the European Research Council under the European Union's Seventh Framework Programme (FP7/2007-2013)/ERC grant agreement no. 226144. We are grateful to Xiaobin Wang of CAMS, Mingzhi $\mathrm{Xu}$ and Baohui Yin of CRAES, Ruijun Jin of TJWMO, Shuiyuan Cheng of BJUT, and other staff and graduate students for their contributions to the IPAC-NC campaign 2006. We thank Chuenyu Chan of PolyU/SYSU, Xiaobin Xu, Xiangdong Zheng and Hongbing Cheng of CAMS, and Sihua Lu and Min Shao of PKU for their help 
on VOC sampling and analysis and Benedikt Steil of MPIC for providing the EMAC model results. We also thank the guest editor Alex B. Guenther and the three anonymous reviewers for their constructive comments on the manuscript. This paper is dedicated to Wei Wang for his great contributions to atmospheric chemistry research, especially aircraft measurements of air pollution in China.

Edited by: A. B. Guenther

\section{References}

Akimoto, H.: Global air quality and pollution, Science, 302, 17161719, doi:10.1126/science.1092666, 2003.

Apel, E. C., Emmons, L. K., Karl, T., Flocke, F., Hills, A. J., Madronich, S., Lee-Taylor, J., Fried, A., Weibring, P., Walega, J., Richter, D., Tie, X., Mauldin, L., Campos, T., Weinheimer, A., Knapp, D., Sive, B., Kleinman, L., Springston, S., Zaveri, R., Ortega, J., Voss, P., Blake, D., Baker, A., Warneke, C., Welsh-Bon, D., de Gouw, J., Zheng, J., Zhang, R., Rudolph, J., Junkermann, W., and Riemer, D. D.: Chemical evolution of volatile organic compounds in the outflow of the Mexico City Metropolitan area, Atmos. Chem. Phys., 10, 2353-2375, doi:10.5194/acp-10-23532010, 2010.

Atkinson, R. and Arey, J.: Atmospheric degradation of volatile organic compounds, Chem. Rev., 103, 4605-4638, 2003.

Barletta, B., Meinardi, S., Simpson, I. J., Atlas, E. L., Beyersdorf, A. J., Baker, A. K., Blake, N. J., Yang, M., Midyett, J. R., Novak, B. J., McKeachie, R. J., Fuelberg, H. E., Sachse, G. W., Avery, M. A., Campos, T., Weinheimer, A. J., Rowland, F. S., and Blake, D. R.: Characterization of volatile organic compounds (VOCs) in Asian and north American pollution plumes during INTEX-B: identification of specific Chinese air mass tracers, Atmos. Chem. Phys., 9, 5371-5388, doi:10.5194/acp-9-5371-2009, 2009.

Boersma, K. F., Eskes, H. J., Veefkind, J. P., Brinksma, E. J., van der A, R. J., Sneep, M., van den Oord, G. H. J., Levelt, P. F., Stammes, P., Gleason, J. F., and Bucsela, E. J.: Near-real time retrieval of tropospheric $\mathrm{NO}_{2}$ from OMI, Atmos. Chem. Phys., 7, 2103-2118, doi:10.5194/acp-7-2103-2007, 2007.

Chan, C. K. and Yao, X.: Air pollution in mega cities in China, Atmos. Environ., 42, 1-42, 2008.

Chen, D. and Shen, X.: Recent progress on GRAPES research and application, Q. J. Appl. Meteorol., 17, 773-777, 2006.

Chen, Y., Zhao, C., Zhang, Q., Deng, Z., Huang, M., and Ma, X.: Aircraft study of Mountain Chimney Effect of Beijing, China, J. Geophys. Res., 114, D08306, doi:10.1029/2008jd010610, 2009.

Cheng, H. and Wang, M.: Difference in nonmethane hydrocarbons (NMHCs) between urban and rural atmospheres, Meteorol. Sci. Technol., 38, 668-672, 2010.

Commane, R., Floquet, C. F. A., Ingham, T., Stone, D., Evans, M. J., and Heard, D. E.: Observations of $\mathrm{OH}$ and $\mathrm{HO}_{2}$ radicals over West Africa, Atmos. Chem. Phys., 10, 8783-8801, doi:10.5194/acp-10-8783-2010, 2010.

Cooper, O. R., Parrish, D. D., Stohl, A., Trainer, M., Nedelec, P., Thouret, V., Cammas, J. P., Oltmans, S. J., Johnson, B. J., Tarasick, D., Leblanc, T., McDermid, I. S., Jaffe, D., Gao, R., Stith, J., Ryerson, T., Aikin, K., Campos, T., Weinheimer, A., and Avery, M. A.: Increasing springtime ozone mixing ratios in the free troposphere over western North America, Nature, 463, 344-348, 2010.
Crounse, J. D., Paulot, F., Kjaergaard, H. G., and Wennberg, P. O.: Peroxy radical isomerization in the oxidation of isoprene, Phys. Chem. Chem. Phys., 13, 13607-13613, 2011.

Crutzen, P. R. and Andreae, M. O.: Biomass burning in the tropics: Impact on atmospheric chemistry and biogeochemical cycles, Science, 250, 1669-1678, 1990.

de Reus, M., Fischer, H., Sander, R., Gros, V., Kormann, R., Salisbury, G., Van Dingenen, R., Williams, J., Zöllner, M., and Lelieveld, J.: Observations and model calculations of trace gas scavenging in a dense Saharan dust plume during MINATROC, Atmos. Chem. Phys., 5, 1787-1803, doi:10.5194/acp-5-17872005, 2005.

Dickerson, R. R., Li, C., Li, Z., Marufu, L. T., Stehr, J. W., McClure, B., Krotkov, N., Chen, H., Wang, P., Xia, X., Ban, X., Gong, F., Yuan, J., and Yang, J.: Aircraft observations of dust and pollutants over northeast China: Insight into the meteorological mechanisms of transport, J. Geophys. Res., 112, D24S90, doi:10.1029/2007jd008999, 2007.

Ding, A. J., Wang, T., Thouret, V., Cammas, J.-P., and Nédélec, P.: Tropospheric ozone climatology over Beijing: analysis of aircraft data from the MOZAIC program, Atmos. Chem. Phys., 8, 1-13, doi:10.5194/acp-8-1-2008, 2008.

Ehhalt, D. H.: Photooxidation of trace gases in the troposphere Plenary Lecture, Phys. Chem. Chem. Phys., 1, 5401-5408, 1999.

Farina, S. C., Adams, P. J., and Pandis, S. N.: Modeling global secondary organic aerosol formation and processing with the volatility basis set: Implications for anthropogenic secondary organic aerosol, J. Geophys. Res., 115, D09202, doi:10.1029/2009jd013046, 2010.

Fiedler, V., Nau, R., Ludmann, S., Arnold, F., Schlager, H., and Stohl, A.: East Asian $\mathrm{SO}_{2}$ pollution plume over Europe - Part 1: Airborne trace gas measurements and source identification by particle dispersion model simulations, Atmos. Chem. Phys., 9, 4717-4728, doi:10.5194/acp-9-4717-2009, 2009.

Geng, F. H., Tie, X. X., Xu, J. M., Zhou, G. Q., Peng, L., Gao, W., Tang, X., and Zhao, C. S.: Characterizations of ozone, $\mathrm{NO}_{\mathrm{X}}$, and VOCs measured in Shanghai, China, Atmos. Environ., 42, 6873-6883, doi:10.1016/j.atmosenv.2008.05.045, 2008.

Gurjar, B. R., Butler, T. M., Lawrence, M. G., and Lelieveld, J.: Evaluation of emissions and air quality in megacities, Atmos. Environ., 42, 1593-1606, 2008.

Hatakeyama, S., Takami, A., Wang, W., and Tang, D.: Aerial observation of air pollutants and aerosols over Bo Hai, China, Atmos. Environ., 39, 5893-5898, 2005.

Hocking, W. K., Carey-Smith, T., Tarasick, D. W., Argall, P. S., Strong, K., Rochon, Y., Zawadzki, I., and Taylor, P. A.: Detection of stratospheric ozone intrusions by windprofiler radars, Nature, 450, 281-284, http://www.nature.com/nature/journal/v450/ n7167/suppinfo/nature06312_S1.html, 2007.

Hofzumahaus, A., Rohrer, F., Lu, K., Bohn, B., Brauers, T., Chang, C.-C., Fuchs, H., Holland, F., Kita, K., Kondo, Y., Li, X., Lou, S., Shao, M., Zeng, L., Wahner, A., and Zhang, Y.: Amplified Trace Gas Removal in the Troposphere, Science, 324, 1702 1704, doi:10.1126/science.1164566, 2009.

Jacob, D. J., Crawford, J. H., Kleb, M. M., Connors, V. S., Bendura, R. J., Raper, J. L., Sachse, G. W., Gille, J. C., Emmons, L., and Heald, C. L.: Transport and Chemical Evolution over the Pacific (TRACE-P) aircraft mission: Design, execution, and first results, J. Geophys. Res., 108, 9000, doi:10.1029/2002jd003276, 2003. 
Jimenez, J. L., Canagaratna, M. R., Donahue, N. M., Prevot, A. S. H., Zhang, Q., Kroll, J. H., DeCarlo, P. F., Allan, J. D., Coe, H., Ng, N. L., Aiken, A. C., Docherty, K. S., Ulbrich, I. M., Grieshop, A. P., Robinson, A. L., Duplissy, J., Smith, J. D., Wilson, K. R., Lanz, V. A., Hueglin, C., Sun, Y. L., Tian, J., Laaksonen, A., Raatikainen, T., Rautiainen, J., Vaattovaara, P., Ehn, M., Kulmala, M., Tomlinson, J. M., Collins, D. R., Cubison, M. J., E., Dunlea, J., Huffman, J. A., Onasch, T. B., Alfarra, M. R., Williams, P. I., Bower, K., Kondo, Y., Schneider, J., Drewnick, F., Borrmann, S., Weimer, S., Demerjian, K., Salcedo, D., Cottrell, L., Griffin, R., Takami, A., Miyoshi, T., Hatakeyama, S., Shimono, A., Sun, J. Y., Zhang, Y. M., Dzepina, K., Kimmel, J. R., Sueper, D., Jayne, J. T., Herndon, S. C., Trimborn, A. M., Williams, L. R., Wood, E. C., Middlebrook, A. M., Kolb, C. E., Baltensperger, U., and Worsnop, D. R.: Evolution of organic aerosols in the atmosphere, Science, 326, 1525-1529, doi:10.1126/science.1180353, 2009.

Jöckel, P., Tost, H., Pozzer, A., Brühl, C., Buchholz, J., Ganzeveld, L., Hoor, P., Kerkweg, A., Lawrence, M. G., Sander, R., Steil, B., Stiller, G., Tanarhte, M., Taraborrelli, D., van Aardenne, J., and Lelieveld, J.: The atmospheric chemistry general circulation model ECHAM5/MESSy1: consistent simulation of ozone from the surface to the mesosphere, Atmos. Chem. Phys., 6, 50675104, doi:10.5194/acp-6-5067-2006, 2006.

Kanakidou, M., Mihalopoulos, N., Kindap, T., Im, U., Vrekoussis, M., Gerasopoulos, E., Dermitzaki, E., Unal, A., Koçak, M., Markakis, K., Melas, D., Kouvarakis, G., Youssef, A. F., Richter, A., Hatzianastassiou, N., Hilboll, A., Ebojie, F., Wittrock, F., von Savigny, C., Burrows, J. P., Ladstaetter-Weissenmayer, A., and Moubasher, H.: Megacities as hot spots of air pollution in the East Mediterranean, Atmos. Environ., 45, 1223-1235, 2011.

Kanaya, Y., Pochanart, P., Liu, Y., Li, J., Tanimoto, H., Kato, S., Suthawaree, J., Inomata, S., Taketani, F., Okuzawa, K., Kawamura, K., Akimoto, H., and Wang, Z. F.: Rates and regimes of photochemical ozone production over Central East China in June 2006: a box model analysis using comprehensive measurements of ozone precursors, Atmos. Chem. Phys., 9, 7711-7723, doi:10.5194/acp-9-7711-2009, 2009.

Kleinman, L. I., Daum, P. H., Lee, Y. N., Nunnermacker, L. J., Springston, S. R., Weinstein-Lloyd, J., and Rudolph, J.: A comparative study of ozone production in five U.S. metropolitan areas, J. Geophys. Res., 110, D02301, doi:10.1029/2004jd005096, 2005.

Kubistin, D., Harder, H., Martinez, M., Rudolf, M., Sander, R., Bozem, H., Eerdekens, G., Fischer, H., Gurk, C., Klüpfel, T., Königstedt, R., Parchatka, U., Schiller, C. L., Stickler, A., Taraborrelli, D., Williams, J., and Lelieveld, J.: Hydroxyl radicals in the tropical troposphere over the Suriname rainforest: comparison of measurements with the box model MECCA, Atmos. Chem. Phys., 10, 9705-9728, doi:10.5194/acp-10-97052010, 2010.

Kuhn, U., Ganzeveld, L., Thielmann, A., Dindorf, T., Schebeske, G., Welling, M., Sciare, J., Roberts, G., Meixner, F. X., Kesselmeier, J., Lelieveld, J., Kolle, O., Ciccioli, P., Lloyd, J., Trentmann, J., Artaxo, P., and Andreae, M. O.: Impact of Manaus City on the Amazon Green Ocean atmosphere: ozone production, precursor sensitivity and aerosol load, Atmos. Chem. Phys., 10, 9251-9282, doi:10.5194/acp-10-9251-2010, 2010.
Kulmala, M.: Atmospheric science: How particles nucleate and grow, Science, 302, 1000-1001, doi:10.1126/science.1090848, 2003.

Lawrence, M. G. and Lelieveld, J.: Atmospheric pollutant outflow from southern Asia: a review, Atmos. Chem. Phys., 10, 1101711096, doi:10.5194/acp-10-11017-2010, 2010.

Lawrence, M. G., Butler, T. M., Steinkamp, J., Gurjar, B. R., and Lelieveld, J.: Regional pollution potentials of megacities and other major population centers, Atmos. Chem. Phys., 7, 39693987, doi:10.5194/acp-7-3969-2007, 2007.

Lelieveld, J.: Atmospheric chemistry: A missing sink for radicals, Nature, 466, 925-926, 2010.

Lelieveld, J., Berresheim, H., Borrmann, S., Crutzen, P. J., Dentener, F. J., Fischer, H., Feichter, J., Flatau, P. J., Heland, J., Holzinger, R., Korrmann, R., Lawrence, M. G., Levin, Z., Markowicz, K. M., Mihalopoulos, N., Minikin, A., Ramanathan, V., de Reus, M., Roelofs, G. J., Scheeren, H. A., Sciare, J., Schlager, H., Schultz, M., Siegmund, P., Steil, B., Stephanou, E. G., Stier, P., Traub, M., Warneke, C., Williams, J., and Ziereis, H.: Global air pollution crossroads over the Mediterranean, Science, 298, 794-799, doi:10.1126/science.1075457, 2002a.

Lelieveld, J., Peters, W., Dentener, F. J., and Krol, M. C.: Stability of tropospheric hydroxyl chemistry, J. Geophys. Res., 107, 4715, doi:10.1029/2002jd002272, 2002b.

Lelieveld, J., Butler, T. M., Crowley, J. N., Dillon, T. J., Fischer, H., Ganzeveld, L., Harder, H., Lawrence, M. G., Martinez, M., Taraborrelli, D., and Williams, J.: Atmospheric oxidation capacity sustained by a tropical forest, Nature, 452, 737-740, 2008.

Lelieveld, J., Hoor, P., Jöckel, P., Pozzer, A., Hadjinicolaou, P., Cammas, J.-P., and Beirle, S.: Severe ozone air pollution in the Persian Gulf region, Atmos. Chem. Phys., 9, 1393-1406, doi:10.5194/acp-9-1393-2009, 2009.

Levy, H. I.: Normal atmosphere: large radical and formaldehyde concentrations predicted, Science, 173, 141-143, 1971.

Li, C., Marufu, L. T., Dickerson, R. R., Li, Z., Wen, T., Wang, Y., Wang, P., Chen, H., and Stehr, J. W.: In situ measurements of trace gases and aerosol optical properties at a rural site in northern China during East Asian Study of Tropospheric Aerosols: An International Regional Experiment 2005, J. Geophys. Res., 112, D22S04, doi:10.1029/2006jd007592, 2007.

Lin, W., Xu, X., Zhang, X., and Tang, J.: Contributions of pollutants from North China Plain to surface ozone at the Shangdianzi GAW Station, Atmos. Chem. Phys., 8, 5889-5898, doi:10.5194/acp-8-5889-2008, 2008.

Lin, W., Xu, X., Ge, B., and Zhang, X.: Characteristics of gaseous pollutants at Gucheng, a rural site southwest of Beijing, J. Geophys. Res., 114, D00G14, doi:10.1029/2008jd010339, 2009.

Liu, S., Trainer, M., Fehsenfeld, F., Parrish, D., Williams, E., Fahey, D., Hübler, G., and Murphy, P.: Ozone Production in the Rural Troposphere and the Implications for Regional and Global Ozone Distributions J. Geophys. Res., 92, 4191-4207, 1987.

Liu, Y., Shao, M., Zhang, J., Fu, L. L., and Lu, S. H.: Distributions and source apportionment of ambient volatile organic compounds in Beijing city, China, J. Environ. Sci. Heal. A, 40, 18431860, 2005.

Liu, Ying, Shao, Min, Lu, Sihua, Chang, Chih-chung, Wang, Jia-Lin, and Chen, Gao: Volatile Organic Compound (VOC) measurements in the Pearl River Delta (PRD) region, China, Atmos. Chem. Phys., 8, 1531-1545, doi:10.5194/acp-8-1531- 
2008, 2008

Lou, S., Holland, F., Rohrer, F., Lu, K., Bohn, B., Brauers, T., Chang, C.C., Fuchs, H., Häseler, R., Kita, K., Kondo, Y., Li, X., Shao, M., Zeng, L., Wahner, A., Zhang, Y., Wang, W., and Hofzumahaus, A.: Atmospheric $\mathrm{OH}$ reactivities in the Pearl River Delta - China in summer 2006: measurement and model results, Atmos. Chem. Phys., 10, 11243-11260, doi:10.5194/acp-10-11243-2010, 2010.

Lu, K., Zhang, Y., Su, H., Brauers, T., Chou, C. C., Hofzumahaus, A., Liu, S. C., Kita, K., Kondo, Y., Shao, M., Wahner, A., Wang, J., Wang, X., and Zhu, T.: Oxidant $\left(\mathrm{O}_{3}+\mathrm{NO}_{2}\right)$ production processes and formation regimes in Beijing, J. Geophys. Res., 115, D07303, doi:10.1029/2009jd012714, 2010.

Ma, J. and van Weele, M.: Effect of stratospheric ozone depletion on the net production of ozone in polluted rural areas, Chemosphere - Global Change Science, 2, 23-37, 2000.

Ma, J., Liu, H., and Hauglustaine, D.: Summertime tropospheric ozone over China simulated with a regional chemical transport model 1. Model description and evaluation, J. Geophys. Res., 107, 4660, doi:10.1029/2001jd001354, 2002a.

Ma, J., Tang, J., Zhou, X., and Zhang, X.: Estimates of the chemical budget for ozone at Waliguan Observatory, J. Atmos. Chem., 41, 21-48, doi:10.1023/A:1013892308983, 2002b.

Ma, J., Zhou, X., and Hauglustaine, D.: Summertime tropospheric ozone over China simulated with a regional chemical transport model 2. Source contributions and budget, J. Geophys. Res., 107, 4612, doi:10.1029/2001jd001355, 2002c

Ma, J., Chen, Y., Wang, W., Yan, P., Liu, H., Yang, S., Hu, Z., and Lelieveld, J.: Strong air pollution causes widespread haze-clouds over China, J. Geophys. Res., 115, D18204, doi:10.1029/2009jd013065, 2010.

Madronich, S.: Photodissociation in the atmosphere: 1. Actinic flux and the effects of ground reflections and clouds, J. Geophys. Res., 92, 9740-9752, 1987.

Madronich, S. and Calvert, J. G.: The NCAR master mechanism of the gas-phase chemistry-Version 2.0, The National Center for Atmospheric Research, Boulder, Colorado. Rep. NCAR/TN333+STR, 1989.

Madronich, S. and Calvert, J. G.: Permutation reactions of organic peroxy radicals in the troposphere, J. Geophys. Res., 95, 5697$5715,1990$.

Mao, J., Ren, X., Brune, W. H., Olson, J. R., Crawford, J. H., Fried, A., Huey, L. G., Cohen, R. C., Heikes, B., Singh, H. B., Blake, D. R., Sachse, G. W., Diskin, G. S., Hall, S. R., and Shetter, R. E.: Airborne measurement of $\mathrm{OH}$ reactivity during INTEX-B, Atmos. Chem. Phys., 9, 163-173, doi:10.5194/acp-9-163-2009, 2009.

Mao, J., Jacob, D. J., Evans, M. J., Olson, J. R., Ren, X., Brune, W. H., Clair, J. M. St., Crounse, J. D., Spencer, K. M., Beaver, M. R., Wennberg, P. O., Cubison, M. J., Jimenez, J. L., Fried, A., Weibring, P., Walega, J. G., Hall, S. R., Weinheimer, A. J., Cohen, R. C., Chen, G., Crawford, J. H., McNaughton, C., Clarke, A. D., Jaeglé, L., Fisher, J. A., Yantosca, R. M., Le Sager, P., and Carouge, C.: Chemistry of hydrogen oxide radicals $\left(\mathrm{HO}_{\mathrm{x}}\right)$ in the Arctic troposphere in spring, Atmos. Chem. Phys., 10, 58235838, doi:10.5194/acp-10-5823-2010, 2010.

Martinez, M., Harder, H., Kubistin, D., Rudolf, M., Bozem, H., Eerdekens, G., Fischer, H., Klüpfel, T., Gurk, C., Königstedt, R., Parchatka, U., Schiller, C. L., Stickler, A., Williams, J., and
Lelieveld, J.: Hydroxyl radicals in the tropical troposphere over the Suriname rainforest: airborne measurements, Atmos. Chem. Phys., 10, 3759-3773, doi:10.5194/acp-10-3759-2010, 2010.

Meng, Z. Y., Xu, X. B., Yan, P., Ding, G. A., Tang, J., Lin, W. L., Xu, X. D., and Wang, S. F.: Characteristics of trace gaseous pollutants at a regional background station in Northern China, Atmos. Chem. Phys., 9, 927-936, doi:10.5194/acp-9-927-2009, 2009.

Molina, L. T., Kolb, C. E., de Foy, B., Lamb, B. K., Brune, W. H., Jimenez, J. L., Ramos-Villegas, R., Sarmiento, J., ParamoFigueroa, V. H., Cardenas, B., Gutierrez-Avedoy, V., and Molina, M. J.: Air quality in North America's most populous city overview of the MCMA-2003 campaign, Atmos. Chem. Phys., 7, 2447-2473, doi:10.5194/acp-7-2447-2007, 2007.

Molina, L. T., Madronich, S., Gaffney, J. S., Apel, E., de Foy, B., Fast, J., Ferrare, R., Herndon, S., Jimenez, J. L., Lamb, B., Osornio-Vargas, A. R., Russell, P., Schauer, J. J., Stevens, P. S., Volkamer, R., and Zavala, M.: An overview of the MILAGRO 2006 Campaign: Mexico City emissions and their transport and transformation, Atmos. Chem. Phys., 10, 8697-8760, doi:10.5194/acp-10-8697-2010, 2010.

Molina, M. J. and Molina, L. T.: Megacities and atmospheric pollution, J. Air Waste Manage. Assoc., 54, 644-680, 2004.

Pan, X. L., Yan, P., Tang, J., Ma, J. Z., Wang, Z. F., Gbaguidi, A., and Sun, Y. L.: Observational study of influence of aerosol hygroscopic growth on scattering coefficient over rural area near Beijing mega-city, Atmos. Chem. Phys., 9, 7519-7530, doi:10.5194/acp-9-7519-2009, 2009.

Peeters, J. and Muller, J.-F.: $\mathrm{HO}_{\mathrm{x}}$ radical regeneration in isoprene oxidation via peroxy radical isomerisations. II: experimental evidence and global impact, Phys. Chem. Chem. Phys., 12, 1422714235, 2010 .

Pilling, M. J.: Atmospheric chemistry: Update on Amazonian atmosphere, Nature Geosci., 5, 168-169, 2012.

Pope, C. A. and Dockery, D. W.: Health effects of fine particulate air pollution: lines that connect, J. Air Waste Manage. Assoc., 56, 709-742, 2006.

Ramanathan, V., Chung, C., Kim, D., Bettge, T., Buja, L., Kiehl, J. T., Washington, W. M., Fu, Q., Sikka, D. R., and Wild, M.: Atmospheric brown clouds: impacts on South Asian climate and hydrological cycle, P. Natl. Acad. Sci. USA, 102, 5326-5333, doi:10.1073/pnas.0500656102, 2005.

Ren, X., Harder, H., Martinez, M., Lesher, R. L., Oliger, A., Shirley, T., Adams, J., Simpas, J. B., and Brune, W. H.: $\mathrm{HO}_{\mathrm{x}}$ concentrations and $\mathrm{OH}$ reactivity observations in New York City during PMTACS-NY2001, Atmos. Environ., 37, 3627-3637, 2003.

Robinson, A. L., Donahue, N. M., Shrivastava, M. K., Weitkamp, E. A., Sage, A. M., Grieshop, A. P., Lane, T. E., Pierce, J. R., and Pandis, S. N.: Rethinking organic aerosols: Semivolatile emissions and photochemical aging, Science, 315, 1259-1262, doi:10.1126/science.1133061, 2007.

Rohrer, F. and Berresheim, H.: Strong correlation between levels of tropospheric hydroxyl radicals and solar ultraviolet radiation, Nature, 442, 184-187, 2006.

Russo, R. S., Talbot, R. W., Dibb, J. E., Scheuer, E., Seid, G., Jordan, C. E., Fuelberg, H. E., Sachse, G. W., Avery, M. A., Vay, S. A., Blake, D. R., Blake, N. J., Atlas, E., Fried, A., Sandholm, S. T., Tan, D., Singh, H. B., Snow, J., and Heikes, B. G.: Chemical composition of Asian continental outflow over the 
western Pacific: Results from Transport and Chemical Evolution over the Pacific (TRACE-P), J. Geophys. Res., 108, 8804, doi:10.1029/2002jd003184, 2003.

Seinfeld, J. H. and Pandis, S. N.: Atmospheric Chemistry and Physics, John Wiley and Sons, New York, 1998.

Shao, M., Lu, S., Liu, Y., Xie, X., Chang, C., Huang, S., and Chen, Z.: Volatile organic compounds measured in summer in Beijing and their role in ground level ozone formation, J. Geophys. Res., 114, D00G06, doi:10.1029/2008jd010863, 2009.

Sheehy, P. M., Volkamer, R., Molina, L. T., and Molina, M. J.: Oxidative capacity of the Mexico City atmosphere - Part 2: A $\mathrm{RO}_{\mathrm{x}}$ radical cycling perspective, Atmos. Chem. Phys., 10, 69937008, doi:10.5194/acp-10-6993-2010, 2010.

Shirley, T. R., Brune, W. H., Ren, X., Mao, J., Lesher, R., Cardenas, B., Volkamer, R., Molina, L. T., Molina, M. J., Lamb, B., Velasco, E., Jobson, T., and Alexander, M.: Atmospheric oxidation in the Mexico City Metropolitan Area (MCMA) during April 2003, Atmos. Chem. Phys., 6, 2753-2765, doi:10.5194/acp-62753-2006, 2006.

Sillman, S.: The relation between ozone, $\mathrm{NO}_{\mathrm{x}}$ and hydrocarbons in urban and polluted rural environments, Atmos. Environ., 33, 1821-1845, 1999.

Singh, H. B., Brune, W. H., Crawford, J. H., Flocke, F., and Jacob, D. J.: Chemistry and transport of pollution over the Gulf of Mexico and the Pacific: spring 2006 INTEX-B campaign overview and first results, Atmos. Chem. Phys., 9, 2301-2318, doi:10.5194/acp-9-2301-2009, 2009.

Sinha, V., Williams, J., Lelieveld, J., Ruuskanen, T. M., Kajos, M. K., Patokoski, J., Hellen, H., Hakola, H., Mogensen, D., Boy, M., Rinne, J., and Kulmala, M.: OH reactivity measurements within a boreal forest: Evidence for unknown reactive emissions, Environ. Sci. Technol., 44, 6614-6620, doi:10.1021/es101780b, 2010.

Solomon, P., Cowling, E., Hidy, G., and Furiness, C.: Comparison of scientific findings from major ozone field studies in North America and Europe, Atmos. Environ., 34, 1885-1920, 2000.

Stockwell, W. R., Kirchner, F., Kuhn, M., and Seefeld, S.: A new mechanism for regional atmospheric chemistry modeling, J. Geophys. Res., 102, 25847-25879, doi:10.1029/97jd00849, 1997.

Taraborrelli, D., Lawrence, M. G., Crowley, J. N., Dillon, T. J., Gromov, S., Grosz, C. B. M., Vereecken, L., and Lelieveld, J.: Hydroxyl radical buffered by isoprene oxidation over tropical forests, Nature Geosci., 5, 190-193, 2012.

Volkamer, R., Sheehy, P., Molina, L. T., and Molina, M. J.: Oxidative capacity of the Mexico City atmosphere - Part 1: A radical source perspective, Atmos. Chem. Phys., 10, 6969-6991, doi:10.5194/acp-10-6969-2010, 2010.

Wang, T., Nie, W., Gao, J., Xue, L. K., Gao, X. M., Wang, X. F., Qiu, J., Poon, C. N., Meinardi, S., Blake, D., Wang, S. L., Ding, A. J., Chai, F. H., Zhang, Q. Z., and Wang, W. X.: Air quality during the 2008 Beijing Olympics: secondary pollutants and regional impact, Atmos. Chem. Phys., 10, 7603-7615, doi:10.5194/acp-10-7603-2010, 2010.

Wang, W., Ma, J., Hatakeyama, S., Liu, X., Chen, Y., Takami, A., Ren, L., and Geng, C.: Aircraft measurements of vertical ultrafine particles profiles over Northern China coastal areas during dust storms in 2006, Atmos. Environ., 42, 5715-5720, 2008.
Wang, Y., Hao, J., McElroy, M. B., Munger, J. W., Ma, H., Chen, D., and Nielsen, C. P.: Ozone air quality during the 2008 Beijing Olympics: effectiveness of emission restrictions, Atmos. Chem. Phys., 9, 5237-5251, doi:10.5194/acp-9-5237-2009, 2009.

Wu, X. J., Jin, Z. Y., Huang, L. P., and Chen, D. H.: The software framework and application of GRAPES model, J. Appl. Meterol. Sci., 16, 539-546, 2005.

Xu, J., Ma, J. Z., Zhang, X. L., Xu, X. B., Xu, X. F., Lin, W. L., Wang, Y., Meng, W., and Ma, Z. Q.: Measurements of ozone and its precursors in Beijing during summertime: impact of urban plumes on ozone pollution in downwind rural areas, Atmos. Chem. Phys., 11, 12241-12252, doi:10.5194/acp11-12241-2011, 2011.

Xu, X. D., Zhou, X. J., and Shi, X. H.: Spatial structure and scale feature of the atmospheric pollution source impact of city agglomeration, Science in China, Ser. D Earth Sciences, 48, Supp. II, 1-24, 2005.

Xue, J. S., Zhuang, S. Y., Zhu, G. F., Zhang, H., Liu, Z. Q., Yan, L., and Zhuang, Z. R.: Scientific design and preliminary results of three-dimensional variational data assimilation system of GRAPES, Chin. Sci. Bull., 53, 3446-3457, doi:10.1007/s11434008-0416-0, 2008.

Yan, P., Tang, J., Huang, J., Mao, J. T., Zhou, X.J., Liu, Q., Wang, Z. F., and Zhou, H. G.: The measurement of aerosol optical properties at a rural site in Northern China, Atmos. Chem. Phys., 8, 2229-2242, doi:10.5194/acp-8-2229-2008, 2008.

Zhang, L., Jacob, D. J., Boersma, K. F., Jaffe, D. A., Olson, J. R., Bowman, K. W., Worden, J. R., Thompson, A. M., Avery, M. A., Cohen, R. C., Dibb, J. E., Flock, F. M., Fuelberg, H. E., Huey, L. G., McMillan, W. W., Singh, H. B., and Weinheimer, A. J.: Transpacific transport of ozone pollution and the effect of recent Asian emission increases on air quality in North America: an integrated analysis using satellite, aircraft, ozonesonde, and surface observations, Atmos. Chem. Phys., 8, 6117-6136, doi:10.5194/acp-8-6117-2008, 2008a.

Zhang, Q., Ma, X. C., Tie, X. X., Huang, M. Y., and Zhao, C. S.: Vertical distributions of aerosols under different weather conditions: Analysis of in-situ aircraft measurements in Beijing, China, Atmos. Environ., 43, 5526-5535, doi:10.1016/j.atmosenv.2009.05.037, 2009a.

Zhang, Q., Streets, D. G., Carmichael, G. R., He, K. B., Huo, H., Kannari, A., Klimont, Z., Park, I. S., Reddy, S., Fu, J. S., Chen, D., Duan, L., Lei, Y., Wang, L. T., and Yao, Z. L.: Asian emissions in 2006 for the NASA INTEX-B mission, Atmos. Chem. Phys., 9, 5131-5153, doi:10.5194/acp-9-5131-2009, 2009b.

Zhang, Y. H., Hu, M., Zhong, L. J., Wiedensohler, A., Liu, S. C., Andreae, M. O., Wang, W., and Fan, S. J.: Regional Integrated Experiments on Air Quality over Pearl River Delta 2004 (PRIDE-PRD2004): Overview, Atmos. Environ., 42, 61576173, doi:10.1016/j.atmosenv.2008.03.025, 2008b.

Zhao, B., Wang, P., Ma, J. Z., Zhu, S., Pozzer, A., and Li, W.: A high-resolution emission inventory of primary pollutants for the Huabei region, China, Atmos. Chem. Phys., 12, 481-501, doi:10.5194/acp-12-481-2012, 2012.

Zhu, S., Butler, T., Sander, R., Ma, J., and Lawrence, M. G.: Impact of dust on tropospheric chemistry over polluted regions: a case study of the Beijing megacity, Atmos. Chem. Phys., 10, 38553873, doi:10.5194/acp-10-3855-2010, 2010. 